


\section{Jihrary}

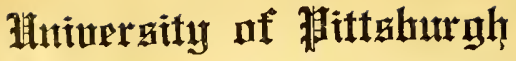

\section{Darlington Memorial Library \\ Ulaba F 459 \\ 确口吥

$$
18 M 2
$$

by Jobn Campbell, who, in conjunction with Jolun Connelly, owned the tract of land lald off iutoa town, that is now embraced in the most valuable part of the city. The helrs of Cumpbell, some twenty in number, who are not however, his direct descendants, but mostly grtat-grandchildren of his sister, Mrs. Beard, claim that they can show clear titles to all the property claimed, which was in the hands of irustees nutil 1S62, when the last one dled, and the property was lost sight of. $\mathbf{A}$ : James Mulloy has rented a bouse ou the levee from the Campbell heirs, adjoiulng the property about to be converted into a wharf, which would include that leased by hlm, and he has notified the Mayor that he will not give up possession of the premises; and a test case is to be had in a suit of ejectment. to be brought on his refusal to move out. 


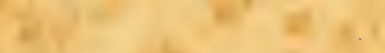

, $1201+1$

. -

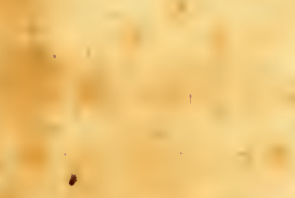

,
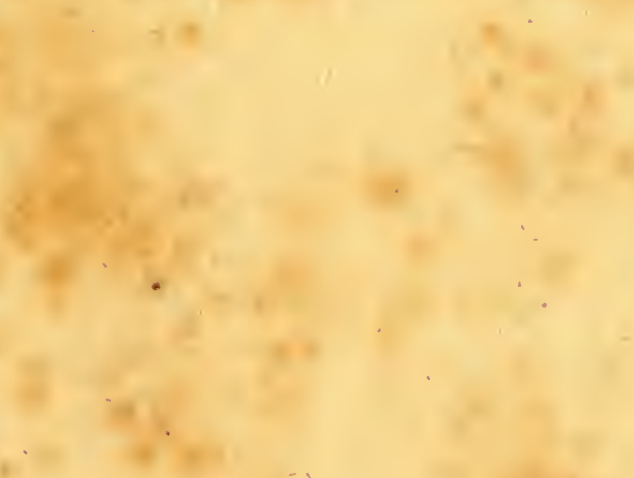

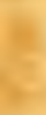

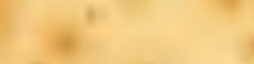

$+2+2$

$+4$

$=0$

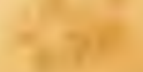

$+1$

$-1$
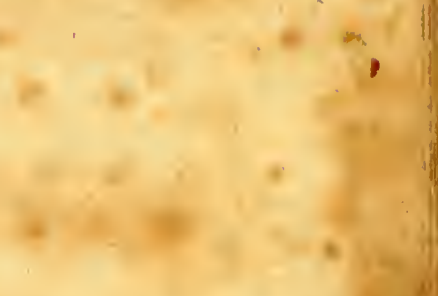


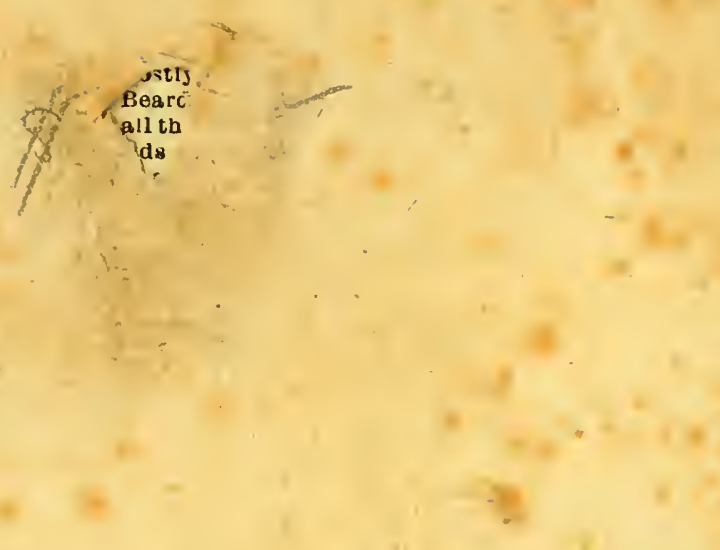

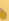

d 




\section{SIRETCHFS}

\section{OF \\ L O U IS I L L L \\ And its Environs;}

INCLUDING, AMONG A GREAT VARIETY OF MHSCELLANEOUS MATTER, A

\section{FLORULA LOUISVILLENSIS;}

OR, A CATALOGUE OF

Nearly 400 Genera and 600 Species of Plants, that grow in the Vicinity of the Town, exhibiting their Generic, Specific, and Vulgar English Names.

\section{eriti \\ BY II. M'MURTRIE, M. D. \&e. 1793- ‥}

Me nec tam patiens Lacedæmon,

Nec tam Larissec percussit, campus opim $x$, Quam domus Albureæresonantis,

Lt præeeps Ohio ac Tiburni lucus et uda,

Mollibus pomaria Rivis.

Hor. car. vii. lib. i.

TO WHICH IS ADDED

\section{AN APPENDIX,}

Containing an accurate Account of the Earthquakes experienced here fion the 16th December, 1811, to the Th February, 1812, extracted principally fiom the Papers of the late J. Brookes, Esq.

\section{FIRST EDITION.}

\section{LOUISVILLE,}

PRINTED BY S. PENN, JUN. MAIN-STREET, 


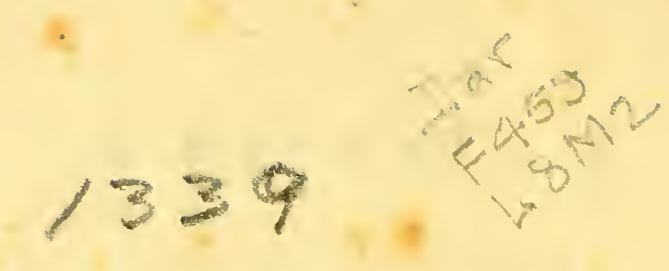

$\left.\begin{array}{l}\text { UNITED STATES OF AMERICA, } \\ \text { DISTRICT OF KENTUCKY. }\end{array}\right\}$ Sct.

$\mathrm{BE}$ it remembered that on the 4th day of February, in the year of our Lora, one thousand eight liundred and nineteell, and in the $43 \mathrm{~d}$ year of the lndependenee of the United States: H. M'Nurtrie of the said distriet hath deposited in this office, the title of a Book, the right whereof he claims as author, in the following words and figures, to wit :

"Shetches of Louisville and its Envirous, including, among a great variety of " miscellaneous matter, a Florula Lotisvillensis; or, a Catalogue of nearly "four hundred Genera, and six hundred specics of Plants that grow in the viciu" ity of the town, exhibiting their generic, specific, and vulgar English names :

BY H. M'MURTRIE, M.D. \&c.

"Me nec tam patiens Lacedamon,

". Nec tam Larissce percussit eampus opima,

"Quam domus flbunece resonantis,

" Et proceps Ohio ac Tiburni lucus et uda, "Nollibus pomaria Rivis._— Hor. car, vii. lib. $\dot{t}$.

"To which is added, an Appendix, containing an aecurate Account of the. " Earthquakes experienced here from the 16 th December, 1S11, to the 7 th "Fcbruary, 1812, extracted principally from the papers of the late Jared "Brooles, Esq."

In eonformity to the Act of Congress of the United Statcs, entitled "An Act for the encouragement of learning, by securing the copies of Maps, Charts, and Books to the authors aud proprietor's of such copies during the time therein mentioned," and also an Act enticled "An Act supplementary to an Act entitled an Aet for the encouragement of learning, by securing the eopies of DIaps, Charts, and Books to the authors and proprietor's of such copies, during the times therein mentioned, and extending the henefits thereof to the arts of designing, engraving, and etching historical and other prints."

$$
\text { [L. S.] }
$$


HIS EXCELIENOY

\section{JAMES MONROE,}

PRESIDENT OF THE UNITED STATES OF MMERICA,

\section{THIS WORK}

IS. MOST RESPECTFULLY INSCRIBED,

BY

HIS OBEDIENT SERVANT,

THE AUTHOR, 


\section{HIS EXCELLENCY JAMES MONROE,}

President of the United States of America. ,

SIR,

Unskilled in the language of flattery, and but little versed in the mysterious art of dedication, I am at a loss what apology to offer, for having thus prefixed your illustrious name to these pages, unless you will be pleased to receive as such, the character so universally assigned to you, as a Patriot, anxious for the advancement of any undertaking that tends to throw the least light upon the resources of any portion of this, his belored country; a country which under the sage and steady conduct of its present rulers, is hastening with giant strides to that conspicuous and elevated rank among the nations of the earth, which must necessarily result from the power of our happy and united, because virtuous republic. That you, Sir, may 
long continue to grace the eminent station to which you have been called by the unanimous voice of a free people, is the sincere wish of every true American, and of none more than of your excellcncy's

Most obedient servant,

H. M'MURTRIE. 


\section{REMARKS.}

To the indulgence of criticism the following sheets have some peculiar claims; they have been written under the pressure of sickness and in the presence of other powers equally tremendous, a situation by no means favorable to classical purity of style, or elegance of composition. To neither of them do they pretend, although it is hoped they may escape the charge of any gross violation of the laws of language.

To the public in general some little apology is due for thus intruding upon their attention, a book of "shreds and patches;" it has, however, been wrested from my hands by a portion of their own borly; so that should disgust attend a perusal of its pages, the weight of their resentment must partially recoil upon themselves. The "request of friends" is an excuse so stale and hacknied that, like the "Nolo Episcopari," it is never uttered but it excites a smile of incredulity bordering on contempt; it is notwithstanding in the present instance, to the importunate nature of the former, that the Sketches 
of Louisville are indebted for their existence. Aware that I had been engaged in collecting matcrials for a work relative to the history of this town and its surrounding country, and knowing that I had been cut short in the prosccution of that design, by circumstances of a private nature, that forbid every hope of my being able to resume it, a promise was extorted from nie to arrange. the few notes I! had taken, and to give them to the public in some trifling form, which, while it had no pretensions to the perfection, of a picture, might still exhibit to people at a dis. tance, the slietch of a place, whose situation and resources are now the subject. of universal speculation. Long ere this promise was made, I had abandoned the subject and neglected $m y$ daily Meteorological researches, so that when I resumed it, I found that many of my papers lad been destroyed or lost; and among the rest, a series of tables constructed from a varicty of thermometrical observations, demonstrating by comparison with others taken in the Atlantic states, the superior milhness of climate, of the countries situated in the valley of the Ohio, to those of the former, under the same parallel of 
latitude. 'This was a serious, and to me, irrepas: rable loss, the more to be regretted, as the truth of the position, though ably supported by well established and incontrovertible facts, has lately been contested-Many and various were the vexations and difficulties I had to encounter. The task was troublesome. My mind and body had lost considerably of their energy, and it was with reluctance I proceeded. My word, however, was passed, and I have thus fulfilled it; having now perhaps only to reap the reward of a pledge too inconsiderately bestowed, in the attacks of a "genus irritabile vatum," to which, ere they bare their stings, I would recommend the observation of Shenstone, relative to the union of true criticism and good nature.

II. M'M.

Falls of Ohio, July, 1819. 

latitude. This was a scrious, and to me, irepas: rable loss, the more to be regretted, as the truth of the position, though ably supported by well established and incontrovertible facts, has lately been contested-Many and various were the vexations and difficulties I had to encounter. The task was troublesome. My mind and body had lost considerably of their energy, and it was with reluctance I proceeded. My word, however, was passed, and I have thus fulfilled it; having now perhaps only to reap the reward of a pledge too inconsideratcly bestowed, in the attacks of a "genus irritabile vatum," to which, ere they bare their stings, I would recommend the observation of Shenstone, relative to the union of true criticism and good nature.

H. M'M.

Fulls of Ohio, July, 1819. 


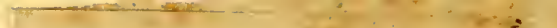




\section{INTRODUCTION.}

\section{CHAPTER 1.}

Louisville is situated in the state of Kentucky and county of Jefferson, in latitude $38^{\circ} .10^{\prime}$ north, upon an elevated and beautiful plain, on the south bank of the Ohio, in a great southern bend of that river, and immediately opposite its falls, being at or near the South West corner of an extensive tract of low country, somewhat of an ohlong figure, that reaches to the lakes.

By casting an eye over a connected map of the states of Kentucky, Indiana, Ohio, and the Miami Country, the boundaries of this immense valley (if so it may be termed) will readily be perceived to consist of two elevated, though broken ranges of highlands, one of which is known in the vicinity of the falls by the name of the Knobs, the other by that of the Silver Creek Hills. The former commencing a little below the mouth of Salt-River, run South Fast about 
one hundred and twenty miles to the easterboundary of Madison county, thence north east the same distance to the Ohio above Maysville, where, crossing the river they are seen a little east of the Pickaway Plains, pursuing the same course; the latter, rising in a high cliff, within a few hundred yards of the Ohio and adjoining the Town plat of Albany, (whose western boundary they constitute) stretch out in nearly a north easterly direction,to the Michigan territory, forming a paralel line with the one described by the Knobs in their progress to Lake Erie.

The whole of this tract, with few exceptions, is extremely similar in its general appearance whether it be viewed, with the inquisitive and searching cye of the Geognost or the more superficial glance of the common traveller. The one, every where, beholds the same formation characterized, by the nature and position of the Rock, the paucity of its metalic productions, the abundance of its saline ones, and the existence of those alluvial deposits, the debris of former ages, which together, with other circumstances, carry the most inestable conviction to his mind, that he is now treading on a spot once occupicd 
by the deep and placid waters of a Lakc bounded by the Knobs and Silver Creek Hills, then doubtless much higher than at present: The other gazes with delight upon the number of beautiful streams, which interrupting his passage, are every where seen rolling their tribute to the Ocean, bearing on their foaming bosoms, the products of the lovely country through which they pass. If accident or design should lead him into the surrounding high country, how is he struck with admiration at the sight of meadows containing from five, to a hundred thousand acres lying on one uninterrupted level, covered with a profusion of Flora's most favorite gifts, and composed of the richest soil that any people under the canopy of Heaven can boast of! He sees that nothing more is requisite to prepare the Prairie* for the reception of that seed which it is sure to return him a thousand fold, than to burn up the grass and set in his plow: all the toil of cutting down trees and clearing away the stubborn relics of forests, in which the greater part of those who migrate to a new

* The name by which these extensive natural meadows are generally lmown in the Western Country. In the state of Kentucky alone it is calculated there are upwaras of half a milion of acres of this description, which are now rapidly. settling. 
country pass the most valuable portion of their lives, is here by the bounty of indulgent nature spared him. Heaving a sigh, at the thoughts of the different nature of that sterile spot, to which perhaps necessity compels him to return, he continues his route drawing comparisons between the ultra and cismontane countries, by nomeans unfavorable to the latter.

The lower part of the Southern and Western portion of this extensive region, which principally claims our attention atpresent, may be divided into the high and low country, which vary considerably in their aspect and elevation, the first being higher by two or three lundred feet than the second and presenting no ponds, marshes, or modern alluvial formations, which so strongly mark the other.

The site of Louisville, which is in the second division, is part of a triangular alluvial plain, whose greatest inclination is not more than $1^{\circ}$ south, extending in that direction 20 miles to the mouth of Salt river; its greatest breadth opposite the town being six miles, which gradually diminishes to one, as it approaches its Southern boun* dary. 
Ponds, marshes, and planispherical accumulations of sand, the two former of which disfigure its surface and taint the wholesome gale with nauseous vapours, are now gradually disappearing, before the active energy, and opening eyes of the awakened citizens who seem to be convinced that "their fate is in a great measure put into their own hands," and that if they will not remove these prolific sources of discase, they must and ought to suffer the penaliies thereto annexed.

There are no data, from which we can with any degree of certainty compute the elevation of this plain above the waters of the Ocean, but taking it for grauted that Brownsville lies eight hundred and fifty feetabove the level of the Atlantic, and allowing (according to the mode pursued by Dr. Drake in estimating the height of Cincinnati) a fall in the bed of the river from that place to this one of nine inches per mile, we shall find that Louisville stands four hundred and seventy four, and the surrounding highest country one thousand and seventy five feet above the Ocean.

Every part of the section of Kentucky of which we are speaking, is finely irrigated by a 
number of navigable rivers and their branches, which latter interlock in so extensive a manner as to intersect the country in every direction.Among the principal of these is the

\section{OHIO,}

By far the noblest river in the universe, no matter in what point of view it be considered. It is formed, by the junction of the Allegheny and Monongahela in lat. $40^{\circ}, 26^{\prime}, 16^{\prime \prime}$ north, when passing through Pennsylvanid, it washes the shores and constitutes the line of division between the states of Virginia and Kentucky on the one hand, and Ohio, Indiana and the Illinois territory on the other, receiving in its progress through one of the most pleasant and fruitful countries upon earth a number of sister streams, all anxious to mingle in the train of their Queen and mistress, who, thundering o'er the Falls, hushes her tumultuous waves, and winds her way in silent majesty to the Lat of $379^{\circ} 00^{\prime} 21^{\prime \prime}$ north where joining the Mississippi, they together seek the Ocean. 
The average heighth to which the waters of the Ohio are frequently and suddenly raised, may be estimated at fifty five fect, although for several years past, during the spring and fall freshets, they have attained one of $-60-$. The same causes operating upon the minor streams, produce nearly similar effects. The Kentucky having been known to rise 50 or 60 feet in 48 hours. The velocity of the current, during these periods is equal to five miles per hour, except while passing over the falls where it is considerably encreased. Below this the navigation is seldom. interrupted for more than a day or two by ice, which is partly owing to the mildness of the climate and partly to the impetus of the current.

The length of this truly "Belle Riviere" including that of the Allegheny (which is but a continuation of it) is nearly thirteen hundred miles, which (as observed by Dr. Drake) is three times the length "of the Susquehanna including the "Chesapeake Bay, and four times that of the "Potomac, Delaware, Hudson, or Connecticut "Rivers." It's average breadth may be estimated at 600 yards, opposite Louisville however, 
it is one mile and twenty-five poles wide, presenting the most expansive and beautiful prospect, any where to be met with in the United States.

\section{KENTUCKY.}

T"he Kentucky is one of the finest rivers of the Western Country, originating in three principal branches, called the Southern, Middle, and Northern Forks, the latter of which, by much the largest, heads in the Cumberland mountain. From the junction of these forks, which interlock with the head waters of Licking river, and from below the mouth of Red river one of its tributary branches, it runs in a north westerly direction to the Ohio, through a country remarkable for the fertility of its soil, and the sublimity of the scenery exhibited on the banks of its water courses, some of which are from four to five hundred feet in heighth, crowned with groves of red Cedar, which furnish ample stupplies of that valuable timber to the Louisville 
market. About seventy miles from its mouth in a most romantic situation is placed the town of Frankfort, the seat of the Legislature of the state. From its origin to where it empties into the Ohio, the Kentucky, besides Red and Dick rivers, two considerable streams, receives an infinity of smaller ones, some of which by interlocking with the head waters of Rock Castle and Salt rivers, pour their refreshing currents in every direction. This beautiful stream is 160 yards wide at its mouth, and is navigable one hundred and thirty miles.

\section{HARROD'S CREEK,}

Is a valuable stream emptying into the Ohio, nine or ten miles above Louisville, where it is forty yards wide. About a fourth of a mile from its mouth, is a natural fall of 6 or 7 feet, occasioned by the oblique direction of the rock forming its bed, which dips at an angle of $7^{\circ}$. It has been reported that like many others in this state, it has found a subterraneous passage, 
through which a great part of the water fiows; without crossing the falls.

\section{BEAR-GRASS,*}

Which gives its name, to the fertile and wealthy settlement through which it passes, is, a considerable mill stream, affording a plentiful supply of water, eight or ten months in the year. It rises by eight different springs, 10 miles east of Louisville, that unite and form the main body of the creek within two miles of that place. This like the preceding one, sometimes disappears, pursuing a secret course for a quarter of a mile together subsequently emerging with a considerable force, on its banks are several grist mills and one for paper. It enters the Ohio, (to which for the last half mile it runs nearly parallel) opposite Louisville, leaving between it and the river, an elevated slip of land, covered with

* A Bridge was thrown over this creek near its mouth during the last summer, but owing to the miserable mode of forming the abutments, they in a few weeks gave way, and the superstructure was consequently preeipitated into the water. This is a lesson to those whose business it is to superintend such matters, not to be so economical, and for the future instead of employing a Carpenter or Stone Cutter, to have the advice and assistance of a professional Engineer, in all public works of this nature. Where the ereek crosses the main turnpike road leading to Lexington about two miles from the town is another one, constructed of stone that is neat and durable. 
large trees, that afforels a delightful and shady promenade to the citizens during the heats of summer.

At the mouth of this Creek, is one of the best harbors on the Ohio, perfectly safe and commodious for all vessels under 500 tons burthen, there being 12 feet water constantly found here during the greatest depression of the river. It is from this harbor or basin that the contemplated Canal will be supplicd with its destined element, which may perhaps produce a beneficial effect, by quickening its motion and that of Bear-grass, whose sluggishness during the summer, is, I have no doubt, productive of consequences injurious to the health of the inhabitants of the town.

\section{SILVER CREEK,}

A small stream of not much value, emptying into the Ohio below Clarksville. In its banks however, are found large quantities of Copperas, and Alum might be produced with little ex- 
pense, from the schist which forms the rock through which it runs.

\section{SALT RIVER,}

Is a very valuable one, navigable nearly sixty five miles. It is formed by three principal streams and an infinity of smaller branches, the most northern of the former being called Floyd's fork, the southern Rolling and Beach forks. On the latter is situated Bardstown, the seat of the Catholic Bishop of the state, and the residence of a number of erudite men, who are occupied in establishing several institutions of learning. On the waters of this stream some of which interlock with those of the Kentucky and Green rivers are an infinity of Salt Licks, whence it receives it's name. The three principal branches which wind in a westerly course, to the Ohio, unite about sixteen miles from, and empty into it twenty miles below Louisville.

This beautiful river is nearly one hundred and sixty yards wide at its mouth, and from the 
quantity of Salt that, with proper attention and chemical knowledge, might be produced from the country it intersects, may be regarded as one of the most important of the state.

\section{THE FALLS.}

The falls of the Ohio are caused by a body of Limestone that stretches across its bed, operating like a dam upon the river above, which finding its course interrupted, continues to swell, until rising superior to the obstruction, it rushes down the declivity by a thousand different passages, to the lower end of Rock Island.

A line drawn from the point of Bear-grass creek to the lower end of Jeffersonville, crossing the river obliquely, and one drawn from Mill Creek to the lower" point of Rock Island, will include between them what are properly termed the Rapids, for although the rock extends below Sandy Island, yet on its south side it is sufficiently excavated to form a deep channel while on the north it is considerably more elevated, allowing boats to pass in higl water only, and when the river is low, it is perfectly dry. 
There are three channcls, in which vessels occasionally descend, the northern and principal of which is termed the Indian Chute*, the southern one or that leading between Corn and Pock Islands and the Kentucky shore, the Kentucky Chute, (which empties into a beautiful basin called Rock harbor hereafter to be noticed,) and the one running between Goose and Rock Islands, which is the most eligible of the three when the water is at a mcdium lieight called the middle Chute.

The draught of the falls commences above Jeffersonville, whence the velocity of the current gradually increases to the great break of the Indian Chute at $H$, fiom which to $J$ it runs ten miles one thousand and sixty six yards per lour, from $J$ to $K$ thirteen and an half miles per hour, and thence to the line drawn from Mill creek to Rock Island, nine miles and nine hundred and ninety nine yards per hour, making in all three thousand three hundred and sixty-six yards in ten minutes and thirty five seconds, which is equal to ten miles and one thousand four hundred and eighty two yards per hour.-

*: Generally but improperly waitten Schute. 
The top of the Pock at the head of the Rapids is found to be 2 it feet higher than the bed of the river above it, so that the fall below, is equal to the same.

The Indian Chute is the main channel and the one generally preferred (unless the water be at its lowest stage when it with all others are impassable) as there is no sudden or perpendicular fall throughout its course. The great difficulty cxperienced in it, arising from the numerous fragments and spines of rock, whose menacing points every where present themselves, occasioning a violent commotion of the water, through which the boat is propelled so rapidly, as renders it at times impossible for human strength or skill, to prevent her from being dashed against some of them.

The bottom of this channel at its commencement, is furrowed out by the action of the water, presenting to the eye, a number of ridges, sharp spinous projections and many isolated blocks of rock, rarying in size from a barrel to a hogshead, some of which resemble inverted cones, resting upon their apices. Those near $H$. rise a foot above the current, and are not wider apart than? 
10 or 12 fect, the consequence of which is, that somc boat or other is frequently lodged there. The brig Kentucky was driven on them, and the ships Tuscarora and Rufus King, were wrecked a little to the right.

Below $M$ if the water be low, the foaming waves are quieted, and collected into one deep and solid column, move serenely down the winding path; but let a moderate rise ensue, and the sccne is quickly altered; every rock which before shewed its naked surface, is now completely covered, three fourths of the whole river is attracted by the main channel above $N$, is forced through the narrow pass between Goose Island and the opposite point, is there opposed by the reef $H$, over which it is forced with tremendous violence, when sheering to the right it pauses for a moment, then with redoubled strength lashes the rock that projects from the middle point.When the risc of the river is from 2 to 4 feet, the velocity of the current is greater here than at any other place, while amidst this wild uproar and confusion, the trembling navigator feels sensible that safety is only to be sought for, in the presence of mind and skill of his pilot. 
More than half of the fall in the middle chute, is below a line drawn from $B$ in the main to $B$ in the Island, above which, the water would be ncarly level with that above the Rapids, if large quantities of it did not escape through the chasms in Goose Island, and fall from 10 to 12 fect, into the Indian Chute:

The Kentucky Chute, or that south of Com Island, is navigable in time of high water only, the river falling, leaves but a small stream close under the Island, and when it is low, nothing is to be seen, but a bed of rock that extends to the basin front of Louisville, and a shoal which bounds said basin on the north, as far as the point of Bear-grass. This shoal and the reef of Goose Island, diminish the suction of the Indian Chute, thereby enabling the fearful stranger to escape its jaws and reach in safety the harbor of Bear-grass.

A proposition to improve the channel of the Indian Chute by blasting and removing the spines, ridges and blocks, already described, has been frequently made, but when we take into consideration the probable expense (and there is no possibility of calculating the real one) of doing 
this effectually, (and to do it by halves, would be worse than useless,) it seems improbable that it. ever will be attempted; it would be much better to expend $\$ 300,000$ on a Canal which would to a certainty remove every difficulty, and yield ever after a handsome interest on the capital employed, as well as furnish an infinity of sites for manufactories, to which it.would afford a power equal to 24 feet fall, than to risk $\$ 100,000$ on the problematical issue of an undertaking similar to the first, which even admitting it to exceed, would never yield a single sous of revenue. 


\section{SKETCHES OF LOUISVILLE.}

\section{GEOGRAPHICAL MINERALOGY.}

In attempting a sketch of the Mineralogical Geography of the surrounding country it is necessary to premise, that although the rock throughout the whole of it belongs to the floctz limestone, being a portion of one of the largest formations of that description in the known world, yet such is the irregularity of its appearance that a correct idea canno: be entertained of it, by confining ourselves to an examination, at any one particular point. In the prosecution of this subject therefore, we will begin with sub-stratum, visible at the lower end of the Indian Chute in the rapids, and endeavor to give as correct an account as possible of the superincumbent ones, as they are found in the immediate vicinity of the falls, subsequently noticing those of the higher portions of the same low tract, and conclude with the higher country, which has an elevation of 600 feet above the former. 
The lowest or first stratum then, of which we have any precise knowledge, is a sheet of Limestone of a bluish grey colour, imperfectly crystalized, of an average spec. gravity of 2.67 , which furnishes but indifferent lime, valuable however for building purposes, remarkable for containing vast numbers of some unknown fossil*, and being the principal bed of that enormous quantity of Bram Stonesi spoken of hereafter. It rises 10 feet above low water mark; to what depth it extends below is unknown.Succecding this we have one of a very different. aspect and texture; it is of an ashy grey colour, a specific gravity of 2.65 , fracture perfectly conchoidal and carthy, presenting no marks of crystalization whatever, penetrated by minute schistose particies, and extremely friable if exposed to the air for any length of time, in which case, it spalls off, and finally crumbles into pieces of a few pounds weight. It contains but very few marine cxuvia, and is equally useless for either building or paving.

Covering the lattcr, we find a third stratum of a close grained compact limestonct, fre*Vice ehap. on organic fossil remains. †Madrep. Cerebrum. †Tha lapis suillis. 
quently containing transparent rhomboidal calcarious crystals, and occasionally cubic ones of sulphate of lime: It is of a bluish colour, specific gravity 2.68, and is filled with fossils of various descriptions, the rock in many instances appearing to be formed of nothing else. These two last strata, are split in every direction, the fissures being filled with an induraîcd petroleum, which is not unfrequently found to interpose between the different sleets, cementing them together. In the upper one, cells are sometimes seen, in which are found from one to two ounces of the same substance in an oily form.

A stratum of aluminous Schist, next makes its appearance, of from 4 to 6 fect in thickness, as viewed from the banks of the river, (whose bed it forms below the rapids) that stretches out north and south from the Ohio into the Knobs and Silver Creek Hills, constituting their basis and that of the adjacent high country. It is very bituminous, frequently contains solubie pyrites, and if thrown upon a fire burns with rapidity, yiclding considerable heat. Impressions of leaves, and of a plant of the Fern family are commonly observed in it. 
Resting upon this slaty bottom we have an alluvial formation consisting of various deposifions, the first of which is a bed of blue, and in some places a deeply coloured ycllow clay, that is laid immediately or the Schist: the second, a loose sand, disposel in a waving position, in which water is found so plentifully as to prevent the inhabitants from sinking their wells deeper in search of it; the third a yellow clay, which is covered in its turn by sand similar to the former, the whole being crowned with rich loain ten feet in depth.

Such were the appearances presented by the first bank, or bottom, (front of and a little below Louisville on which Shippingport is built,) in digging the foundations for Mr. Tarascon's mill. They vary however considerably from thost $\mathrm{x}$ hibited on the route of the contemplated canal, which runs but few hundred yards from it, by the shafts, that were left open for some time to public ohservation. 'Throughout the whole of its track, but two strata one of yellow clay mixed with fine sand, the other, a blue clay, mixed with the same material, are found to intervene between the loam on the surface and the rock below. 
This irregularity dxtends to the second bank, where we find alternate and various strata of sand and clay, until we arrive at the depth of 40 feet, where there is always found a bed of gravel, composed of water worn pebbles, presenting specimens of all the various rocks both primitive and secondary, that compose the Allegheny, Appalachian, Cumberland, Clinch and Gauley mountains, such as, Granite of various kinds, Kneiss, Trapp, Hornblend, Schorl, Sennite, \&c.

If we now take a view of the higher portions of this same low tract, we may observe, as on the banks of Harrod's Creek, a vast body of a spongy light cellular limestone, indeterminately.stratified, at least 100 feet deep, that is fissured in every direction, and penetrated by a number of perpendicular holes resembling wells, and below this a regularly stratified lime-rock, containing a number of fossils, some few of which are found in the upper one.

The latter appears to be in a constant state of decomposition, as the surface of it is covered with a soft calcarious earth, which if removed, speedily forms again.

On the Kentucky river uear Frankfort, we. 
see numerous and beautiful sheets of a fine grained white marble, commencing with the river (whose bed it constitutes) and rising to the heighth of one hundred and forty or fifty feet, by a regular series of steps, formed by the outgoings of the different strata; and immediately on this a coarse shelly limestone containing large quantities of marine exuvia, that reaches to the top of the cliff, which is from 3 to 400 feet above the water.

The same arangement is evident on the banks of Dick's river, and at Danville, and indeed this upper stratum appears to extend generally throughout this part of the country, varying however in appearance, in different places, as near Marble creck, a small stream emptying into the Kentucky river, below Boonsborough, where it runs into a hard compact marble, susceptible of a high polish, presenting a gorgcous assemblage of colours, such as black, blue, crimson, and yellow.

In the neighborhood of Harrodsburgh it seems wholly composed of oyster shells, and on the plantation of Wm. Cochrane near Silver creek, Madison county, of a spccies of Buccinum, a 
small univalve shell that is found fossil no where clse.

Although it is very evident that the rock in this low country as well as in the higher onc, was originally deposited in perfectly horizontal and unbroken sheets, yet is it impossible, to find a single square mile of it, that is not fissured, and thrown up out of its original level, by violent concussions of the earth, that (the opinion of Mr. Volney to the contrary notwithstanding) must have been fiequently felt and consequently noticed by the aborigines. Had that gentleman ever visited the head waters of the Kentucky and Cumberland rivers, he would there have seen it forced up from its horizontal position, to one presenting an angle of $45^{\circ} . *$

It may not perhaps be uscless here to remark, that however these terrible. phenomena may threaten destruction for the monent, yct they

*Admitting this fact (and to deny it ane must be "sand blind "s "sone blind," $*$ r wilfully blind, a degree of blindness equal to both the orhers) to suppose that the original inhabitants, had no word in their language to communicate it to one another, appears to me too glaring an absurdity to need a comment. During: the year 1812, Black Feather a Shawnee chief, and Perry another Indian of the same rank, on their way to Fort MIeigs with the American troops, wcre sitting in a tent, in company with several of the latter, when the earth began to oscillate. Before any of the whites present perceived it, Black Feather, swinginghimself from side to side, observed tliat the "earth tottered." An officer asked him if he hat ever before felt a similar sensation, to which the chief counting by the number of Suns, replied in the affirmative, at three different periods dit:fing the last 40 years. This anecdote $I$ have from a gentleman wipo wats glocsent. 
are indispensibly requisite, in rendering habita ble, those portions of the earth, whose formation is similar to our own. Had the rock which forms the basis of this country, and which is most generally very near its surface, been suffered to lie in uninterruptedly solid and horizontal sheets; it would have remained a desert, the present Eden of America, have been a barren waste; every shower that fell, would instantly have disappeared, leaving not a spring or rivulet behind it.

Earthquakes break up the strongest strata and divide them in every direction, forming innumerable receptacles for that kindly dew of Heaven, which is thus permitted to pass off slowIy and by degrees, furnishing in its course, both to man and beast, abundant supplies of one of the first necessaries of life.

\section{OF THE HIGH COUNTRY.}

The lowest stratum of the surrounding high lands is the Schist formerly spoken of, which forms the bed of the Ohio below the falls, ex- 
tending N. and $\mathrm{S}$. into the Knobs and Silver creek hills, in the latter of which it appears to be from 70 to 80 fect thick, and is found to underlay a secondary wacke, ${ }^{*}$ which in the Hills of Madison county, is from 180 to 200 feet in depth.

Resting upon this, we find occusionally, a stratum of a greyish coloured compact modern limestone, that contains but very few animal remains, and those of a very minute description. In some places, it appears to be lamellated, elastic, and considerably sonorous, so as to ring, if struck gently with a hammer. 'The editor of a newspaper informed me that he had a stone for a printing press cut out of it, that possessed these qualities in an eminent degree. In the county of Bracken, 60 or 70 miles south-west from Louisville, this same sheet of limestone makes its appearance, filled with nodules of oil flint, and occasionally interrupted by beds or layers of it; one particular spot seems to have been occupied by the Indians as a factory for arrow heads, knives, \&c. from the tons of chips,

- In the north bank of the river, a thin stratum of floctz trap, or green stone, is sometimes found to succeed the slate. 
lying on the ground scattered in every direction.

Immediately over this limestone stratum, is extended one of sandstone, that in some places in the interior, presents a depth of 300 feet, it makes excellent grindstones, from which persons in the vicinity supply themselves. Between the lead waters of Silver and Station Camp creeks, it runs into a beautiful breccia or pudding stone composed of primitive pebbles chiefly of quartz, a black schorl, that seldom weigh more than an ounce, and a cement formed of lime and sand: it is extremcly valuable for millstones, numbers of which are annually manufactured from it, bearing a character for durability, scldom surpassed by any of the imported ones.

Such is the general disposition of the rock as we proceed west, until we arrive at Clover creek, 70 miles below Louisville, where immense and apparently inexhaustible bodies of coal make their appearance, which abound in regularly stratified soluble pyrites, in such quantities that a single individual has been known to raise upwards of a ton per day. Green river rolls over the coal which ascends 8 feet above low water mark, how deep it may descend being unknown; 
wacke and sandstone, suceessively cover it, and limestone no where makes its appearance.

I have never scen any fragments of primitive rock, in this state, although they are said to be found both here, and in the state of Indiana, and in the Illinois and Missouri territories, where they are denominated lost-stones, from the evident circumstances, of their being strangers to the soil where they are found. From the description given to me of these bodies, I suspect they are composed of granite and gnciss, if so, they must have been brought to the places where they are are now deposited, by masses of ice, detached fiom northern shores, and driven southward by powerful currents, that in all probability have once traversed the whole of this country in that direction.

The country we have been describing, is not particularly remarkable for its metalic productions, although plenty of bog or meadow and kidney iron ore is seattered in every direction, but seldom in sufficiently large and connected bodies, to warrant the erection of works; on Red river, in Estell and in Slate creek, in Bath. county, however, it is found in immense quantities, and of an excęllent qualityi. 
Blende and galena are every where met with, but in such detached and small beds, as render them perfectly useless. Pyrites both soluble and insoluble are contained in the limestone and slate, and it is more than probable, that it will be found in the hills adjoining the chalybeate springs of Jeffersonville.

Small specimens of antimony have been found among the sand thrown up in sinking the wells of the town, and I have a specimen of it mineralized by sulpher, that was brought to me by a person from Indiana, who declared that he knew where it existed in large quantities. I could not prevail upon him to discover the spot. Muriate of soda or common salt, is contained in nearly all the salines, together with so much of the muriats of magnesia and lime, as render the working of them unprofitable. Many of these springs contain epsom salts, the principal sources of which as well as of salt petre are derived from the various caves, with which this country abounds.

In the higher tract of sandstone country, wherever the cliffs impend, so as to keep the subjacent rock and earth dry, this latter article is 
found, and to such an extent in some places, that the rock itself appears to be composed of it: you may break it in pieces with your hand and crumble it into powder; throw it into water, the salt rapidly dissolves, leaving nothing but a small proportion of sand behind it.

There is nothing for which this section of the United States is more remarkable, than its numerous caves, ${ }^{*}$ whose extent and beauty claim our attention and admiration. The most con: siderable of these is the Mammoth Cave, situated on green river, into which visiters are said to have penetrated from eight to nine miles. It contains inexhaustible quantities of salt petre, and is the spot, whence was taken the Indian Mummy lately exhibited in the Atlantic states. To enumerate them all, would be a mere waste of time and paper, as well as a severe tax upon the reader's patience, so that I shall conclude this imperfect sketch with the description of one of them, remarkable, not so much for its extent, as for the value of its contents.

\footnotetext{
* It was my decided intention to have visited the most noted of these carerns. for the purpose of examining into their structure and contents, but professiona business, joined to domestic obstructions, prevented me from prosecuting $\mathrm{mr}$ plan with respect to any but the Mammoth Cave of Indiana.
} 


\section{MAMMO'TH CAVE OF INDIANA.}

This curious and interesting work of nature, is situated in a north-west direction from Corydon the present seat of the legislature of Indiana, being about ten miles from that place, and thirty-four from Louisville.

At what precise period it was first discovered, must be left to tradition and wild conjecture to determine, but it is evident, from circumstances hereafter to be mentioned, that many ages must have elapsed, since that terrible convulsion of the carth, which has in some places, rent asunder the solid rock for a liundred feet together. Although its existence was generally ascertained in '98, it is only since the year 1814 that we have any account of it that can be relied on.

Dr. B. Adams its present proprietor, informed me (while passing through Corydon, on my way. to it) that he had seen and conversed with several persons who had entered it about the time first mentioned. From the description given of it by them to the Doctor, it must have then exlibited a most magnificent and dazzling appearance, especially when we consider, that it is onfy by meaus of flambeaux or torches, that it can 
We viewed at all, the reficction and refraction of whose light, from the immense quantity of crystals that every where presented themselves, nust necessarily have produced a great variety of brilliant colours.

Such was the profusion of salts contained in it, at this period, that, to use their own words, the sides and bottom of it were covered with them like snow, from among which occasionally projected large masses of the same substance. This statement deserves some credit, from the partial corroboration subsequently given to it by General Harrison, who visited the cave in 1806. This gentleman informed Dr. Adams, that there were at that time, enormous lumps of some saline matter scattered over the floor, individual pieces of which, he was persuaded, would have weighed from 1 to 200 pounds.The whole of this crystalized body imust have been an impure sulphate of magnesia, which is still found there, though in small crystals, and only on the sides and in the interstices of the rock, which is owing to all the larger ones having been removed, sevcral waggon loads of which were taken to Frankfort and other places: 
The hill on which this. curious and interesting cavern is formed, belongs to one of those groups which border on. Blue River; that stream rumning within a hundred yards of its base, about three hundred feet from whichs; fronting W.S. W. opens the

\section{MOUTH OF THE CAVE,}

Which forms the half of an irregular oval, about five feet in height Passing under the projecting ledges of rock, you immediately enter a low passage opening downward to the first chamber or vestibule, which is a vaulted apartment of an oval figure, whose longest diameter is forty yards. 'There is nothing here to claim any particular notice, if we except the beauty of the arch formed by the ceiling, which springs from the floor.

And leaving this, a passage presents itself, that winds considerably to the right, varying in breadth from fifteen to twenty feet, and in height from forty to a hundred. The rock, which has hitherto been composed of a bluish grey limestone (the whole formation belonging to the newest floetz) lying in very distinct hori- 
zontal strata, two fect thick, placed immediately over each other, without any intervening substance, is liere of a softer kind of the same stone, with a yellow calcarcous, and in somc places a blue argillaceous earth interposed between them. The ceiling, which, as was before observer, is in some places one hundred feet high, is as perfectly smooth as though it had been plastered by the hand of a mason, its continuity being interrupted only by large fissures of a spheroidal or oval figure, that seem to communicate with cavities above. The inferior (and, as far as can be discerned, the superior) edges of thesc holes are perfectly smooth, and bear ample testimony, as well as do the appearances throughout the cave generally, that water was the agent employed in rounding them.

In this passage the Epsom salt, or sulphate of magnesia, first makes its appearance. It is seen upon the rocks in every direction, shoot-. ing into small crystals; whose lustre is dimmed by. the quantity of dust showered on them from above. This salt appears to be incxhaustible, not only from the quantities seen incrusting the surface, and filling up the spaces 
between the different strata of rock, throughout the vast extent of this pasșage, but from its rapid and continual repreduction; as a proof of which, the owner once had a small projection. that was covered, swept perfectly clean; when in a few montlis it was found as thickly studded as before.

Having gained the end of this hall, which is. at least one hundred and forty yards from the mouth of the cave, you come to an arched door-way, twelve feet in height, that admits you. into a narrow vaulted gallery, running straight forwards for the distance of forty yards, where it turns to the right, and, gradually winding to the left, makes a descent of from ten to twelve feet, at an angIe of $15^{\circ}$. Here you enter a second passage, which enlarges from ten to fifteen feet in width, and which contains most irrefragable proof, that the whole cavity' was once filled by a stream of water, whose rapidity and volume has scooped and furrowed out the rock in every direction, leaving no angular points or projections whatever. In this place I cut out of the left wall a small madrepore, the only fossil vestige of any animal, 
shell, or plant, that I could discover in the cave.

About the middle of the passage we are describing, on the right side, at the height of forty. feet from the ground, there appears to be an immense chasm, occasioned by the recession of the roof from the side that supports it. This aperture having been always considered as opening into another cavern over hearl, I had a ladder constructed, which, with much toil and labour, we succeeded in dragging to the spot and elevating against the rock. One of the party then ascended, and discovered that what had appeared an opening from below, was an optical illusion, occasioned by the oblique direction of the rocks constituting the side, which, at the height before mentioned, instead of continuing to the roof, slaunts off at an angle of $60^{\circ}$, which it is impossible to see from below, owing to the darkness that, notwithstanding your torches, always prevails in front of it.

The earth on which you now tread, contains about five pounds of the nitrate of lime or magnesia, to the bushel, and is composed of decayed animal and vegetable matter, principally 
of bats' dung, which may be secn hanging in. tufts on every rock. A little beyond this, and near the end of the passage, is a small opening, originating from a deep gully to the left, that seems to wind under the main road that leads to the right. It is, however, at a little distance from its commencement, rendered impassable by fragments of rock that choak up the passage. Continuing on the main route for some distance further, the eye is involuntarily attracted by immense pebbles, weighing from one to five hundred tons, that lie precisely in the middle of it. I say pebbles, because, although they are composed of carbonate of lime, they are as completely rounded as any fragment of a primitive rock that can be produced in a water course.

At a little distance from these ponderous masses, the cave forks, at the distance of threequarters of a mile from its mouth; the left hand, however, is passable but for a little distance, the roof having fallen in from above, prevents your further progress. At this spot are the remains of two Indian drawings; the one resembling a savage, armed with a bow and arrows; 
the other is so mucli defaced by the injuries of time, that it is impossible to say for what it may have been intended. Leaving these antique specimens of Indian painting, the road leads to the left, and you speedily make a descent of twenty feet, on an angle of $45^{\circ}$, and are as soon compelled to scramble up an ascent of thirty, at one of $50^{\circ}$.

The road now points N.E. and you find no thing worthy of notice till you arrive at the Rotunda, which is a circular room with a vaulted ceiling, and within a few yards of which you find another small oval apartment, containing nothing remarkable. Leaving this, you enter a low gallery, which brings you to the first serious impediment that presents itself, and which consists in the ceiling or roof of the gallery descending so low as to touch the floor, leaving a small arched opening, through which, whoever wishes to penetrate further, must crawl and

* Being the first of our party who arrived at the top of the latter, I immedi ately scaled the clifts on the left, and gained a projecting point, from whicis was presented to my view, one of the most impressive spectacles that nature, in her wildest and most gloomy mood, ever oftered to the eye of man. The spot $I$ occupied was at least one hundred and forty feet above my companions, whose torches cast a red and lurd glare over their faces, and was just sufticient to shew them embowelled in the earth, surrounded by frightful precipices, and yawning gulplis into which one false step would inevitabiy have plunged them. The intense darkness that shrouded those objects beyond the reach of their fights, as well as the death-like silence that prevailed, contributed not a little to the horrors of a scene on which I gazed so long, as to start at the productions of my owi fancy, which, Salvator-like, pictured a ruftian on every rock. 
scuffle, not on his hands and knees, for that is impossible, from the shallowness of the arch, but, literally speaking, on his belly. This spot has been styled by the guide, and not unaptly, the bats' burial place, the soil on which you creep, to the depth of a foot, being composed entirely of their remains.

Having once moic regained his feet, the visiter entcrs a low gallery, at the end of which is a most beautiful arch; passing through which, he finds himself under a dome, covering a circular room, the correctness of whose proportions is admirable. Another low gallery, similar to the one by which he entered, conducts him to a pile of rocks, at least forty feet high, lying on an ascient of $45^{\circ}$. Having clambered over these, he is immcdiately ushered into the Saloon, one of the most remarkable cxcavations of the whole cavern. It is of an oval figure, about one hundred yards long; the ceiling, which is vaulted, and extremely lofty, springs about thirty feet from the floor, and is enriched with a cornice, the beauty and regularity of whose mouldings excite our astonishment and admiration, and, for a moment, induce us to believe that they 
must have been fabricated by design and the hand of man, not by accident and the rude chissel of nature. It is, indeed, a most spacious and superb apartment, and, with a little trouble, might be rendered a banqueting hall, worthy the presence of Charlemagne and his Peers.

After leaving the saloon, by a low arched door-way there is nothing remarkabie in the passage that presents itself, for the distance of at least 450 yards, but the curious appearance and texture of the rock, wlich is of a milky liue, smoothed and rounded in every direction, and that seems once to have been traversed by an innumerable quantity of orifices, now filled up with a much purer carbonate of lime than that of which the frame (if I may so term it) is composed. How to explain this I confess I.am at a loss, unless ive can suppose it to be the work of some animal, while the rock was yet in a soft state. Small specimens of selenite or sulphate of lime are found here; some of which are perfectly crystalized, while others are opaque, porous, and spongy:

Having followed the windings of the passage, for the distance just mentioned, an exclamation 
of surprise is not unfrequently elicited from the passenger, who, looking down upon his right, beholds a circular grotto, whose ceiling and sides are most magnificently adorned and fretted, with millions of semi-transparent stalactites, of various figures and different colours. On the floor, at the foot of a large stalagnite, is a deep triangular fissure, at the bottom of which is heard the roaring of a torrent of water.

After leaving the grotto, the saline productions of the cave diminish, so as to become scarcely perceptible, and the rock is found to consist of a friable kind of limestone, mixed with schistose particles, very imperfectly cemented together, lying in a horizontal strata of from two to three inches in thickness. Here also may be found what the French mineralogists have denominated fossil flour, of a reddish brown colour, which is probably owing to iron, the sulphate of that metal having been found in the vicinity.

In pursuing this passage, however firm may be his nerves, the visiter cannot help shuddering at being obliged to pass, what has been emphatically called the trap, a flat rock, weighing 
at least a ton, that is suspended directly-over his back (for he is compelled to crawl seven or eight feet under it) supported at two of its acute angles by projections in the sides of the rock of not more than an inch each! It has the appearance of being balanced in air, and threatens to grind to powder the unfortunate wretch who might be unlucky enough to touch it.

From a little beyond this, the cave becomes wet and slippery; the transition from limestone to a kind of slate is evident in the lamellated structure of its parietes, between the thin strata of which are interposed large beds of tenacious blue clay. Any of these plates can be drawn out by the hand, with the greatest ease, and the appearance of the place generally, proclaims it "nodding to its fall" so that I have no doubt 'ere long all ingress will be precluded to the

CHAMBER OF FOUNTAINS,

Which I have thus named from two masses of stalactites that resemble, in the direction of their spars, the various columns of water asscending from a jet d'eau in full play. 'This 
apartment is of a circular figure, with a flat ceiling, about fifty feet from the floor. The only means, however, by which the reader can entertain any idea of the fairy spectacle presented in this enchanted spot, will be to describe it a gencral way, as it is seen from the entrance.

The first object that attracts the eye of the wondering spectator, is an immense stalagmite, of an hemispherical figure, on which rests a group of spars, that presents a striking similitude to a circular fountain, fifteen feet in diameter, forcing up a golden-coloured fluid to the height of twenty feet, in such a manner that those columns which ascend from the larger and outer ranges of pipes all converge in their descent, while those from the smaller and inner ranges of the same, have precisely the contrary direction. Issuing from the top of another conical stalagmite, is a second collection of spars, of about one-fourth the size of the first, that presents an equally interesting and similar spectacle, with this difference-it is surrouniled by sparry concretions, resembling statues in various attitudes, columns, vases, architectural miins, trees bearing fruit, \&c. \&c. 
Immediately in front of this, and to his left hand, is a stalagmitical mass, forming an in= clined plane, reaching from near the spot whereon it stands to the floor at the opposite. side of the chamber. The whole surface of this, together with that of the left half of the ceiling and walls, is covered with every form that the most fruitful fancy, in her wildest moments could imagine.

The great variety of tints with which the pencil of nature has decorated these curious productions, contributes, equally with the diversity of their figure, to the beauty of the scenc. The walls, as well as the stalagmites, are all covered with an incrustation of calc-tuft*, of a blackish colour; while many of the objects spoken of are of a milk white, which is particularly the case with those pendant from the ceiling; some of which have a surface as smooth as polished parian marble, while others are covered with an infinity of minute snowy plumular crystals, that give them an appearance similar to the matted work of the jeweller.

Among the variety of colours that are the

*The spars themselves are all composed of calc-sinter", or sath șiax": 
most striking, may be noticed a lively red, bor dering on a vermillion, a pale rose, and a colour resembling that of unpolished gold. When, in addition to these circumstances, we combine that of some of the spars being nearly diaphanous, while others are perfectly opaque, some faint idea may be entertained of the chamber of fountains.

Without entering into a discussion relative to the general formation of these remarkable caverns so common in this county, I think I may safely venture to assert, that the one in question bears along with it most unequivocal proof of its having originated in an earthquake, which has split the rock, and opened a passage for a superincumbent body of water that has rushed in and filled a part, if not the whole of the cavity: The sides of the cave in the narrower passages, coincide exactly with each other, so that where you perceive a convex projection on one side, there is sure to be a corresponding depression on the other. In short, making allowances for the dilapidations of time, no one can hesitate to believe, that they were once in contact, forming a solid mass of rock; 
The larger cavities or chambers were, no iloubt, formed at one synchronous stroke witls the passages leading to them, their different sizes being easily accounted for from the different degrees of tenuity and hardness exhibicd by the rock, in different places, as well as by supposs. ing the existence of original cavities immediately under them, which served to engulph that portion of it which was loosened from the great body by the violence of the concussion.

That many centuries must have elapsed since that epoch is very evident, from the immense stalactitical masses presented to our view in the chamber of fountains. The large stalagmite on which rests the first fountain, is a hemisphere whose diameter is at least forty feet, and twenty in height! What a length of time must it not have taken for the earthy deposition of water, flowing drop by drop, and apparently as clear as crystal, to have aggregated in such quantities as to have formed these enormous masses? In order to shew how slow the process is, it may be worth while to mention, that about a yard from the base of the first fountain is a small cavity, four inches long, and two deep. 
hollowed out by the action of the water, which still exudes guttatim from the roof above: from the ediges of this cavity spring several columnar bodies, the longest of which is not more than one inch! 'These, it has been remarked, eight br ten years ago, were so nearly the size they are at present, that the difference is impercepible, although increase, they certainly must.

\section{CLIMATE.}

It appears from a variety of thermometrical observations and comparisons, that the climate of this country is uniformly milder than that of the Atlantic states, in the same paralel of latitude. This has been contested, but, until facts and the evidenee of our senses are considered as inferior to theory, the position must be considered as correct. Among the most remarkable of the former, noticed by preceding and able writers, are, the presence of the parakeet, thousands of which enliven our woods, winter and summer, the existence of many plants that cannot support the cold of the Atlantic states, 
in the same latitude, the short duration of ice and sinow, and, finally, by the prevalence of the south-westerly winds. The remark applied by Dr. Pusin, to the cimate of Pcnnsylvania, is equally true with respect to that of Kentucky. (which is, in fact, the most disagrecable of the two) its most steady trait being its irregularity. Heat and cold succecd cach other so rapidly, and so often in the twenty-four hours, that it is impossible to vary your dress so as to be comfortable under their changes.

A sketch of the weather during the last winter will convey as much information upon the subject, as a volume. Eariy in the fall, the Indian Summer as it is called, succeded the Autumn, and lasted four weeks with occasional days of extremely cold weather: this was succeeded by a week of changes the most sudden and extraordinary I crer witnessed, the ponds in the town, being frozen and thawed alternately diring the same day, which was closed by a night equally as rariable. The cold now appeared as though it had commenced in good eamest; during the space of three wecks it was rery intense, quantities of drifting ice were seen on the H. 
Ohio, the ponds were incrusted by it three incli. es deep, when the wind, which had hitherto blown from the $N$. W. suddenly veering to the S. and S. S. W. a warm rain fell, which dissolved the icy fetters of winter, and again restored the Indian Summer. Such was the milduess of the weather till the latter end of January, that the buds of the peach tree were swelled, and had not a few frosty nights supervened, they must have blossomed. On the 7th day of February the weeping willows were in leaf! From which time to the first of March, the weather continued variable, but generally warm, at which period, the cold of winter again assailed our ears, and rendered welcome a blazing hearth.

Spring is unknown, the transition from winter to summer, being almost instantaneous, the former concluding with heavy rains, that I have known to last for three weeks nearly without intermission, at the expiration of which time summer is at hand.

The quantity of rain* that falls here, is very considerable, which, together with the number of stagnant waters that are in the vicinity, occa-

"I have never made but one experiment to determine the precise number of inches and that gave 22 as the result of two weeks constant rain. 
sion a humidity, universally complained of, books, polished steel instruments, paper, and in fact every thing that is not in daily use, proelaim its prevalence.

'Thunder storms during the months of July and August are very scvere, attended with great discharges of the electric fluid, sometimes as violent as any ever witnessed under the tropies, the thunder being of that pealing rattling lind, which would startle even a Franklin. 'The winds at such periods are all in wild confusion, blowing in various directions at various elevations from the earth's surface, as indicated by the courses of the scuds, which I have remarked travelling to three different points of the compass at one and the same moment, with a degree of velocity far superior to any I have ever noticed, with the exception of those of the hurricanes of the East and West Indies. Awful is the scenepresented in the forests at such periods, nought is to be heard but the crackling of falling timber, mixed with the roar of heaven's artillery, and nothing to be seen but great branches, wrenched and torn from the parent stem, which is the next moment levelled with the ground. Sometimes a single tree bere 
or there in exposed situations is destroyed, then again, whole acres are laid waste, by its resistless fury. Happily for this country those of the first degree of violence are rare, while those of the sccond and third rates are not at all dangerous.

The quantity of ice and snow, is very inconsiderate, the cold scldom being sufficiently intense to close the river, and the latter has not at any time since $I$ have been a resident of the place, exceeded two inches in depth at any one time, sleighs are consequently strangers.

I am well assured from very unexceptionable authority that the climate of Kentucky has undergone a considerable change for the worse, during the last twenty years; the scasons were formerly more distinct, the weather, milder and more uniform, and thunder storms very uncommon: the only traces left of this happy state of things, are now to be seen in the fall of the year, which is generally, though not always, remarkable for pleasantuess. Combustion is much more rapid here than in the Atlantic states, a remark made by several others besides myself, Whether this be owing to the spongy and porous 
nature of the wood, arising from its rapid growth, or a greater quantity of oxygen existing in the. atmospinere, I am at a loss to determine, the fact, however, may be relied on.

\section{SOIL.}

Perhaps.no city in the universe is supported by a more fertile and productive soil than Louisville. The lands throughout the country gen, crally, are well timbered, the first rate, being covered with walnut, mulberry, locust, beecl, sugar-tree, cherry, papaw, buckeye, elm, poplar. and grape-vines, the two latter of which attain a most enormous size. I have fiequently met with grape-vines, in the Beargrass settlement, measuring 36 inches in circumference, and as to the poplar it is proverbially gigantic. From 6 to 10 feet is the usual diameter of these trees, and of the sycamore, one individual of which is said to be still standing in the interior, into whose hollow, a gentleman assured me, he had stepped with a measured rod twenty feet long, which, grasping by its midldle he could turn in every 
direction. If in addition to this we consider the thickness of sound wood on cach side of the tree, necessary to sustain its tremendous and superincumbent weight, we may have some idea of this monarch of the western forest.

The second rate lands produce dogwood, oak, hickory and some sugar-trees; the third rate, nothing but blackjack oak and fir'; red cedar is found on the banks of the rivers and creeks, and white pine only in the mountains.*

\section{PRODUCTIONS.}

\section{Lands of the first mentioned description, are} too strong for wheat; corn is the grain usually first planted in such situations, where in favourable seasons it has been known to yield 100 bushels to the acre. Wheat sown in the same ground

* The prices of lands are various, from 10 to 200 dollars per acre, and the titles to all of them not exactly: what could be wished. There are, however, seventy thousand acres of military surveys in the Beargrass settlement, which hold out the prospect of a golden flecce to the agricultural emigrant, not only from the great fertility of the soil and the undisputed validity of the title, but from the great price he can immediately obtain for every article he can raise, without any trouble or difficulty.

In fact, such is the nature of these combined circumstances, that a farmer in the neighborhood of Louisville, upon rentcd ground, can realize more money in ten years, than another with equal industry can do in Ohio or Indiana in twenty, upon that which belongs to himself, so that by the time the lattcr has got his farm into a snug and profitable condition, by dint of hard labour, the former with half the toil, can afford to purchase it from him at a fair valuation, ano bave left besides a sum of money equal to the price. 
weakened by a few crops of Corn averages thirty bushels per acre, Irish potatoes 300, oats 35 to 40 , hemp from 6 to 300 lbs. tobacco from 1,500 to 2,000 lbs. 'The second and third rates of land in proportion. An attempt to cultivate cotton has been made, but although on a small scale under the superintendance of a few good housewives it ripens extremely well, yet on a large one it has always failed.

\section{EXPORTS.}

The principal articles of export, are steam engines, beef, pork, bacon, lard, flour, whisky, tobacco and formerly hemp. Large droves of cattle, beeves and horses are annually taken from the surrounding country to the Atlantic states, which are much more indebted to Kentucky on this score, than their inhabitants are generally aware of.

In addition to the articles above mentioned, may be added, various pieces of household furniture, such as bedsteads, tables, sideboards, chairs, \&c. numbers of which are manufactured, 
for the several fowns between Louisville and New Orleans.*

\section{IMPOR'TS.}

Emopean goods are imported directly from that contincnt; those from the East Indies and from the Atlantic states, are received from Philadelphia, Baltimore or New Orleans, and owing to the facility of iransportation by means of steam boats, principally from the latter. By the same way, we have the coffee and other products of the West Indies, as well as the rice, sugar, cotton, molasses, \&c. of Louisiana. A great change, however, is about to take place in the importation of East India goods, which, (I speak prophetically) ere ten years, will be brought to Louisville direct from China and Bengal via Columbia. The land carriage necessary to eflect the transportation from that river here, not exceeding 360 miles, a distance

* of the quantity of pork annually exported from this place, some idea may we entertained by the following statement:-one individual during the year 1S1s, shippei niile thousand barrels, averaging, each, three bundred and twenty pounds, which gives in all two millions eigh thundred and eighty thousand pounds gross Now allowing that but one half of this quantity was exported by others, we shall hare four millions three hundred and twenty thousand pounds, or thir: teen thonsand five hundred barrels for the whole. 
pot more than equal to that from Philadelphia to Pittsburgl. The great gain of time, and the consequent reduction of the expenses necessarily attendant on those voyages from and back to Philadelphia, Baltimore, or New York, will easily be perceived. The spirit of commerce has already fixed his eye upon the spot, some of his favorites are busied in the project, and ere long those breezes that now fanthe rising town of $\mathrm{As}$ TORIA, may kiss the star spangled banner streaming from the mast of an Indiaman. 


\section{ZOOLOGY.}

CHAPTER II.

THE clk, deer, bear, buffaloe, beaver, and otrer, logether with the various species of squirrel, and other smaller animals common to the American forest, were found in great plenty sas. this place, by the earlier settlers, particularly buffaloes, which have often been seen at the licks, to which they resorted in search of salt, in droves of from seven to eight thousand.

'The roads opened by these animals, in their progress through the woods, may be reckoned anong the natural curiosities of the state, being generally wide cnough for a carriage or waggon way, in which the trees, slirubs, \&c. are all trampled down, and destroyed by the irresistable impetus of the mighty phalanx. Of the vast numbers of these animals, that once covereil the prairies of Kentucky, not one is to be found at the present lour-an enemy to civilized man, they retire before his approaches, and continue to preserve their independence in the heart of the wilderness. 
The same remark may be partially applied to the elk and beaver; the latter of which abounded within a few miles of the town, and, were we permitted to judge from the remains of their fortificutions, we should pronounce them to have been the innumerable possessors of the soil from time immemorial. Every pond, creek, and river, exhibits some traces of them, but their metropolis appears to have been situated about four miles east of Louisville, where, among a variety of extensive dams, I measured onc whose length is fifteen hundred feet, heigth eight, thickness at the base fourteen, with, a talus equal to $45^{\circ}$. extending to the top.

At the end of this bank, which runs perfectly straight, and which is thrown up and sloped in a most workman-like style, is a second one stretching out nearly at right angles from it, in form of a crescent. Back of the latter may be seen their dens, which are disposed with great regularity, about twenty feet from the bank. Their covered ways, by which, in times of low water, they manage to secure a sufficiency of it, so as to conceal themselves in their passage to and from them, are also very visible. I liave 
becn informed by a respectable old gentleman who was among the earlier settlers, that, when he first arrived here, the beaver was sometimes seen in the neighbourhood, and that at that time the great dam spoken of, was at least fourteen feet high, - a prodigious monument of the industry and skill of this social little animal.

The otter has also disappeared from the waters of the Ohio, which once contained great numbers of them, they are, however, still caught in the Mississippi.

Serpents are neither very numerous nor dangerous. Among the most venemous, may be reckoned the rattle snake (crotolus horrida) which I have secn above six feet in length, of a proportionable circumference; and two or three species of coluber, or viper. The most noted of the latter, is the c. cacodaemon, found so commonly in the mountains of the western parts of Pennsylvania. These are seldom seen but among the hills and higher country, while the remainder are perfectly harmlesss

The snapping turtle, testudo serpentina, and the soft shelled turtle, tesdo ferox*, with the

* How this error conld have been committed by the immortal naturalist who named these two different species, or why succeeding ones slrould not lave 
several smaller species of that genus, common to the eastern states are found in the Ohio and on its banks. 'The snapping turte in this river, acquires an almost incredible size, attaining a weight of from fifty to seventy pounls: the soft shelled one never grows so large, but its want of quantity is amply comperisated for, in the exquisite delicacy of its flesh, which is esteemed by the scavans of the eating art, a meat superior to all others, not even excepting the chicken turtle of St. Helena. Deer inhabit the barrens, and are sometimes scen within a few miles of the town, while bears keep themselves buried in the woods at a distance. Foxes occasionally disturb the farmer's hen roosts, and wolves now and then pick up a stray sheep, they are howerer neither very numerous nor fierce.

corrected it, I cannot determine. Certainly Liniæus never had an opportunity of observing personally the habits of the two, or he would never have applied the expletive ferox to a reptile that, from actual observation, is well known to be far from courageons, and which is even timid, when opposed to any thing but its defenceless prey. The other, on the contrary, is indeed a most ferocious animal, who quits lis hold but with the loss of his head, and sometimes not even then, and that has oceasionally been scen to pursue bors who had been teasing him with sticks. Ferox should be the specific appellation of the snapping turtle ; agilis might, with great propriety, be applied to the other, $\bar{a}$, though by no means ferocious or warlize in his disposition, yet he is the most active of the whole genus. Perhaps 1 am wrong in saying that no succeeding naturalIsts bave corrected this erro!', for', if I am ngt mistalien, Pennant has called if the T. mollis. 
To the politeness of that accomplished and skilful naturalist Mr. Rafinesque, I am indebted for a considerable portion of the following catalogues. As most of his specific and some of his generic appellations are new, the reader might be embarassed for want of synonymes, were it not that care has been taken to add the vulgar name to each, which obviates all dithiculty on that score. The list is certainly not complete, the total want of regular fisheries, presenting an almost insuperable obstacle to the acquirement of a full and perfect knowledge of the great variety of the scaly tribe inhabiting the Ohio and its tributary rivers. Those marked $k$. are communications from the gentleman above mentioned-those with an arsterisk, (*) have been added by me, all of which have been seen and examined-those with a single dagger $(f)$ are inserted upon the authority of various individuals, but have not been seen by myself.

1 ACCipenser, lhuso* .

2. Bodianus,

3 Clupea,

calliops R.

1 heterura R.

2 pseudo-harengus* herring

3 sapidissima $\nmid$

4 Crprinus, 1 melanurus r.

2 carpio†

3 gobio*

4 tinca ${ }^{\prime}$

5. Catostonus 1 mellanops $R$.

2 zanthopus R.

3 exiliens R.

4 bubalus R.

5 erythrurus R.

6 duquesni(Lesueur)sucker

6 Esox,
1 vittatus $R$.

2 fasciolaris $\mathrm{R}$. sturgeon

bachelor fish

gizzard fish

shad

black tail $\mathrm{c}_{\mathrm{q}}$

carp

gudgeon

tench

spotted

sucker

mud do,

sailor fish

buffaloe do.

red horse

pike

salmon pike 
7 Exoglossum macropterus $\mathrm{R}$. stone-toter

8 Hydrargyra 1 dinenia $\mathrm{r}$.

2 notata $\mathrm{R}$.

9 Holocentrus 1 trifasciatus $\mathrm{R}$.

\section{2 punctatus R. \\ 3 flabillaris $\mathrm{R}$.}

minnow

chub

ycllow bass

black do.

fan tail do.

10 Lepisosteus fluviatilis (Lacep.) gar fish

11 Muræna, anguilla*

12 Petromison, marinus $\dagger$

13 PercA,
1 salmonea $\mathrm{R}$.

2 chrysops R.

3 ocellata*

4 argentea $R$.
15 Sparus,

16 Salmo,

17 Silurus, 18 Squilla

\section{2 pristis}

\section{cyanelus}

trutta*

5 or 6 species eel

lamprey

salmon

rockfish

perch

white

shovel fish

spade fish

sun fish

salmontrout

cat fish

\section{[whether smooth or}

rough nosed unknown] shrimp

The shad I have understood has been seen occasionally as high up as the falls, it is, however; a very rare visiter. Mr. Rafinesque is of opinion that the herring caught here, is a perfectly new one, and he proposes to call it glossodon ohiensi. 
There may be two species, but the only one I havie seen is cvidently the common American herring which in company with the shad, annually ascends our rivcrs to spawn. One species of catfish is frequently caught in the Ohio, whose tremendous size is proverbial, they being commonly found to weigh one hundred and twenty and sometimes one hurrdred and seventy pounds cach. After a good deal of attention paid to this subject I am well convinced that it is the Silurus Glanis, which attains an equal size in the Oder, one having been taken at Writzen on that river, according to the Abbe Bonaterre, which weighed one hundred and fifty pounds exclusive of the head, fins and entrails. This noble fish is said by those who have tasted of it to be extremely sapid, affording an agreeable and even delicate food. But the most highly prized of the whole list are the salmon, the perch, which weighs from six to thirteen pounds, the salmon trout, the pike and the carp. The shrimp is found in great abundance near the mouth of the Ohio, but at no great distance above it: 


\section{CONCHOLOGY.}

River eivalves.

i. Potamlus, 1 fasciolaris r. muscle

2 phaiedrus $\mathrm{R}$.

3 niger $\mathrm{r}$.

black $\mathrm{m}$.

4 alatus winged $\mathrm{m}$.

5 latissimus r. long $\mathrm{m}$.

6 violacinus

7 fasciatus

8 leptodon

9 fragilis

10 elipticus

11 verrucosus

12 tubercularis

13 gibbosus

14 nodosus

15 obliquatus

16 obovalis

17 subrotundus

18 triqueter

shuff box

19 truncatus 


\section{RIVER UNIVALVES}

2. Lrminu, 1 turricula $\mathrm{R}$.

2 ventricosa Ri.

3 retusa $\mathrm{R}$.

\& lithophila $\mathrm{R}$.

5 eburnea $\mathrm{R}$.

3. Stripona, 1 angularis R. N. G.

2 concolor $\mathrm{R}$.

LAND UNIVALVES.

4. Helix,

5. Mesodon, leucodon R. N. G.

\section{FOSSIL OPGANIC REMAINS.}

The rarious articles of the following catalogue, are described from specimens in my cabinet, the collection and study of which, have occupied seventeen months of unrcmitting attention. That it comprises every fossil to be found here, I will not venture to assert. Thcre are doubtless many genera, and a great variety of speries, that must necessarily have escaped my attention, and there aremany, whose imperfect and comminuted state, defies any attempt at classification or even of descruption.

No apology, I hope, is requisite, for introducing into this chapter, that, which the reader may have already met with elsewhere,-I allude to the remains of those gigantic animals discovered in the licks of Kentucky, whose number and size will ever form a distinguishing trait in its natural history; it's omission would have been an error, as the intention of this catalogue, is to give at one glance, a general view, of the numerous fossils, wth which this section of the Union is so plentifull stocked.

The letters A. B. \&c. refer to specimens of anomalous fossils, so marked in my collection. 
Axonis, placenta

\section{pectinata}

terebratula

gryphoides, spec. 2. anom. Limn. Os-

treac. Brug.

*microscopica

papillata, (typolites, solum.)

plicata

$\mathrm{A}^{* * * *}$ decorata extantibus signis

*These are found in great abundance, mixed. with eñcrinites and the remains of some minute (to me unknown) bivalve shell, all cemented together in the limestone.

A. This is, I believe, a new species, resembling in shape thie A. pectinata. Its surface is most beautifully variegated by a number of deep lines, resembling, in their direction, the fibres of the box tree.

Obs. With the exception of the A. plicata, these are never found compressed; they are most commonly filled with an indurated carbonate of lime, occasionally with six-sided pyramidal crystals of the same, and sometimes with a nnmber of small silicious ones, of a beautiful peach blossom colour. The A. plicata I have 
seen nowhere but in the higher country, it is always perfectly flat.

Ammonita, anomala

\section{tunita proportionata}

tThis was found in the bottom of a pond, in the neighbourhood of the town, carried to Virginia, and lost, through the carelessness of a servant, to whom it was entrusted, on the road. Having never seen it myself, I consequently cannot determine with certainty, but from the very minute description given to me by the gentleman who found it, and who believes it to have been a petrified snake, I have no hesitation in refering it, as above, to Gen. 1. Divis. 1. of Nicolai.

Cardium, serratum islandicum

The species of this last is dubious, as the greater part of the only specimen I have seen is so enveloped in stony matter that the number. of ribs cannot be discerned. They, however, are triangular.

Asterias.

There is only one species of asterite found here. Dr. Johnson has a very perfect one in 
his possession, of which a good drawing is giveu by Professor Mitchill, in his Observations upon the Geology of North America. They are considered by the vulgar as petrified hickory nuts.

Belemnita, lanceolata

mucronata

Generally found from two to three inclies loug, always composed of carbonate of lime, penetrated with needle-like silicious crystals, a small one frcquently terminating their conical points.

Echinus, quadrifasciatus

This is the only tolerable good specimen of: an echinite I have-been able to procure, after a great deal of time and trouble spent in scarching among a quantity of their mutilated remains, which are found on a talus of one of the knobs, together with entrochites, belemnites, gryphites, \&c. that have all been washed out from an isolated bed of blue clay, near the top of the hill, where they appear to have been originally deposited. Spines and portions of their shells (of echinites) may be recognized, but with some difficulty, owing to the quantity of crystalized siliceous earth, that, in some instances,

*All the spines have been broken off, and it has been otherwisc injurer. 
coinpletely envelops them. Dr. Mitchell mertions another of the galerite family, found in Kentucky, which, I presume, must have been taken from this spot.

Ostrea.

Only one species of oyster is to be seen fossil, in this country, which is exclusively confined to the rock, in the higher portions of it. It resembles the common oyster; the shells of the former, however, being smoother and thinner than the latter. From the perfection in which these specimens are found, the valves being com-monly uninjured, it would seem that they were formed in or near the place where they are now deposited; liad they been thrown there, during any extraordinary revolution of the earth, they would necessarily have been broken and have presented other marks of violence.

Buccinum.

Only one species of this genus is to be met with, and what that is, I am not able to determine. The lip is retroverted and thick-it is only found in the high country.

Entrochus, levis

$$
\text { prominens }
$$




\section{verrucosus \\ tserratus}

\section{$\S$ ramosus}

\section{Entrocho-asterio}

On the hill just mentioned, we find severad of the entrochites, spoken of in the "Petrificata Derbiensia," together with others not noticed.

tA new species, whose surface is perfectly smooth. I lave derived the name from the made in which the trochitœ, are joined with one another, which is by a finely serrated suture, whose teeth interlock in a most beautiful manner; to perceive them it is necessary to force the rings apart.

§This is, I think, a valuable, though imperfect specimen, as it is sufficiently whole, to prove the animal nature of the fossil. It is pentagonal, a little curved, and trichotomous. Precisely in the centre of the branches, are small triangular clefts or valves. They are all composed of lamina of plated spar, of great hardness, a bluish colour, and metallic lustre, when recently fractured. By far the greatest proportion of them are compressed, bearing an 
appearance of having been crushed by some weighty body falling perpendicularly on them, in which state numbers may be seen in clusters cemented together by calcarious earth ; their cavities are generally occupied by silicious erystals.

Cellepora, pumicosa

$$
\begin{aligned}
& \text { spongites } \\
& \mathrm{B}^{* * * *}
\end{aligned}
$$

B. A very curious fossil, consisting of pyriform mass, of a reddish hue, which it receives most probably from some martial oxide. The cells are square, and large enough to admit the head of a common sized pin; the tubes arc numerous, closely crowded together, diverging as they ascend, being crossed in a curvilinear direction, by membranous septa running parallel to each other, at one line's distance apart.

Tubipora, several species

Madrepora, †cerebrum

$$
\text { cespitosa, with several others }
$$

†This is found in the most astonishing quantities in the falls, where hundreds of waggon. loads may be collected without any difficulty. varying from six inches to a foot in diameter. 


\section{Corallina, palmata}

indurata

obtusata

And, I doubt not, many others. Cioose Island is nearly covered with them, but in such a miserable and broken condition as renders it next to impossible to find a single specimen that exhibits the number of branches or the shape of the joint. They are all of a dirty yellow colour, and extremely fragile.

Miliolites, several species

Bufo rana, toad, common.

I have been repeatedly assured by different persons worthy of belief, that they have seen these reptiles taken from among the rocks in a fossil state. Never having been so fortunate myself, I cannot vouch for the fact, but what increases the probability of it, is the circumstance of a gentleman living in New-Albany, who has at this moment in his possession, a perfect specimen of the,

Rana, pipiens, or spring frog, completely petrified.

Testudo, picta, small painted water turtle.

It is no uncommon thing to see these littlc 
creatures in a fossil state, their head and feet extended and perfect in every respect. It is a Hittle singular, that although taken in this state, fiom the bottom of ponds and of creeks, yet they have never, so far as I can learn, been seen inclosed by the rock. The head and neck of a snapping turtle was brought to me, a few days past, from the Falls, petrified, and so perfect as to leave not the shadow of a doubt respecting its nature.

Pisces, bones, scales.

Icthyolites are sometimes met with in the upper stratum of limestone rock, in the vicinity of the Falls. They appear to be generally about eighteen inches in length and two in their greatest breadth, evidently all of one species, but so mutilated as renders it impossible to say what that may be. Scales and bones, in a detached state, are found in the same situation.

Somatrikelon, megalomaton* ${ }^{*}$. G.

This is a very curious animal of the vermes class, constituting an entirely new family. At the first view it appears to have three distinct bo-

* Two compound Greek words, owuargixnlov, which signifies a budy divided into three parts, and $\mu \varepsilon$ yaroukatov, having very large eyes. 
dies and but one head, which is owing to the former being very broad (nearly half an inch) and divided throughout its length by two deep clefts, one on each side of the central part or back, which is elevated a fourth of an inch above the sides, is convex, and terminated at one end by a large head, furnished with unusually prominent eyes, and a mouth formed like that of a snapping turtlc. When the specimen was first taken out of the rock in which it was imbeded, (a block of limestone from the Falls, the mouth was perfect, but the under lip was accidentally broken off by some carcless person who was examining it. The whole animal however with this exception, is in a beautiful state of preservation; not the smallest tubercle or wrinkle but what is preserved in its original form. It is composed of a soft limestone, its surface bcing spangled with an infinity of extremely minute calcarious crystals, that give it the appearance of being studded with diamond sparks. I have never seen, nor heard, of but this one specimen.

Diag.-Corpus tripartium, rugosum, sinuatum; extremitate altera acuminata curvataque, dorso, ar- 
cuato, serie tuberculorum utrobique, capite subrotundo, oculis peramplis.

C. Was found among a pile of limestone rocks taken from the bed of Beargrass Creek, and is altogether silicious. Its general appearance resembles that of a number of earth worms furnished with feet, piled one upon another. It is a rare and curious fossil.

Diag.-Animalia petrificata, regulariter coacevata, corporibus annulatis, cylindraceis, elongatis transversim.rugatis, quisque annulus, pendibus binis.

D. A bivalve shell so surrounded with stony matter, that it is difficult to say what it may be. I think it will prove a species of Solen, Mr. Rafinesque has a drawing of it taken from a specimen (the only one I have cver seen) in my collection.

E. Is a production that has caused a good deal of dispute as to its origin. Some persons - being of opinion that it is of vegetable, others of animal nature.

It is a stony cylinder of a serpentine figure sixteen inches in length, a portion of which about seven inches long having been broken off, and 
split precisely in half, gives us a most perfect view of its internal structure.

If the fossil be held so as to look immediately upon its fractured and sected surface, we may. observe,

1 An outer crystalized silicious covering about the eighth of an inch in thickness, corresponding (as they say who consider it vegetable) to the cortex or outer bark of a tree.

2 A filiform calcarious line analogous to the Iiber or inner bark.

3 A second line similar to the first, but at such a distance from it as leaves a space of threefourths of an inch between them which is filled up with a soft fibrous carbonate of lime answering to the alburnum or sap-wood.

4 A once circular cavity one inch in diameter which occupies the centre of the fossil, that is filled with beautifully transparent rhomboidal crystals of carbonate of lime, considered as having constituted the heart.

By turning the specimen round we observe, that the fibres of the calcarious earth interposed between the first and second lines which are considerably elevated and very distinct, radi- 
ate from the circumference of the central cavity to the outer edge of the cylinder, where, instead of being broken off at right angles by the fracturc, they turn over and descend in perpendicular and parallel lines. This is very easily seen, as pieces of the outer covering have scaled off, leaving undisturbed the texture of the part beneath.

If, however, we take one of the fragments and lay it on its convex part, so as to have a view of its split surface, a very different disposition is visible; we now see on each side, the edges of the corticular silicious covering, and of the first and second filiform lines, which latter, instead of being three-fourths, are not more than one-fourth of an inch apart. The fibrous, or alburnum portion, consequently suffers a similar reduction, its texture, being very different, presenting a hardened vitreous surface. It follows necessarily, that the heart or central portion, which before was only one inch in diameter in this position, constitutes the great mass of the whole cylinder, being two inches across. What principally, however, attracts our attention, is an infinity of milk-white thread- 
like lines, composed of a very pure and soft calcarious earth, running in a serpentine and transverse direction over this latter portion, and that penetrate quite through it. A very good idea may be entertained of their appearance by placing the letter $S$ horizontally, and adding a number of others perpendicularly to it, so close together that the curve of one letter is lost in that of the one above and below it. The convex surface of this very extraordinary fossil is studded with a number of elevated circular veruccae, whose superfices are flat, upon which are arranged many small tabular silicious crystals of great hardness.

It would be a matter of presumption in me to say that this is certuinly an animal fossil, but as I am acquainted with no such disposition of $f^{-}$ bres in the vegetable kingdom as is exhibited by the article in question, I am strongly inclined to suspect that it is the habitation of some unknown animal of the vermes class.

F. A number of trifurcated, cylindrical conical pointed bodies, composed of a blackish coloured silicious limestone, are to be seen perforating the lower strata of rock in the falls and 
its vicinity in every direction. The general opinion respecting them is, that they are the roots of trees; the regular nanner in which they fork, however, as well as their external appearance, renders this idea perfectly absurd. They are of various diameter's and of different lengths, the shell resembling shagreen. The reader may have a pretty good idea of them by consulting the works of Brugiere, who gives a drawing in the $62 \mathrm{nd}$ plate of vol. $4 \mathrm{th}$. of a species of Ascidia (fig. 10) to which they bear much resemblance.

$\mathrm{G}^{* * *}$. Is a nondescript fossil, quantities of which are found among the rocks in the bed of the river opposite the town. Their general figure is that of a goose egg, over one half of which is extended a kind of convoluted cap, which is perfectly black, while the remaining portion is of a light grey, on the point covered by the cap are three circular orifices, of considerable depth, large enough to admit the tip of the finger, placed so as to form the three angles of a right angled triangle. I think it not impossible that they may be young cocoa nuts, the similarity between them being very striking. I should indeed, have very little hesitation about the matter, were it 
not for the circumstance of the cap, which is never found wanting.

H. The habitation of some species of 2 coplite. It is a cylindrical fragment, once evidently hollow, three inches in length, and a little curved. It is encircled with a number of rings placed close together, on the superior and convex surfaces of which may be secn several orifices that penetrate obliquely downward and invard to the central cavity, and that are large enough to admit a common sized quill : they are composed of carbonate of lime, silicious earth, nearly filling up the cavities.

I. A fragment of a petrified log of beech wood, lying at Clarke's Point, directly opposite Mr. Tarascon's mills. The main piece from which I took this specimen is about six feet long, and eighteen inches in diameter. It is of a deep indigo colour, penetrated in every direction with pyrites, and exhibits most perfectiy the remarkable grain of this kind of timber.-It had hitherto been considered as the spine of a whale!! Petrified trunks of trees, with their roots and branches have been frequently found imbedded in the rock. Mr. Speed, a gentleman in whose 
veracity I have the most perfect confidence, assured me, that he was cnce present when sinking a well, in search of salt water, (at Bullitt's Lick, if I am not mistaken) the workman came to one of this description; fragments of it were used (one of them by him) as whetstones, for which purpose they answered admirably.

$\mathrm{K}^{* * *}$. Supposed to be a piece of the skin of a shark. There is a large quantity of it enfolded in a block of limestone, lying at the foot of a high bluff, on the north side of the Ohio, ten miles above Louisville.

\section{FOSSIL BONES.}

These gigantic remains have been chicfly taken from the Big Bone Lick, having been deposited in a bed of blue clay, situated between and near the Big Bone Creek, and its most northern branch, small streams of Kentucky emptying into the Ohio, about forty miles below Cincinnati. This, however, is not the only situation in which they are found, as will appear from the following statement.-Those taken from the licks above mentioned, by order of Governor Clarke, have been arranged by $\mathrm{Dr}$. Mitchill, in the following order:- 
1. Bone of the great Mastodon, apparently belonging to the feet.

2. Bones of the leg of the same animal, some of which were in connexion with the former, while others, being separated from them, were scattered through the soil.

3. Bones of the head and upper jaw.

4. Two kinds of teeth; one of which evidently belonged to the Mastodon, others resembling the grinders of the Elephant.

5. Portions of the lower jaw bones, with the teeth firm in the sockets.

6. An enormous tusk, similar to that of the Elephant.

7. Several smaller tusks, the shortest of which was three feet long.

8. Ribs, like those of the Mastodon, and very large vertebrae.

9. The skulls of buffaloes, with the bony cores of their horns.

In addition to these, many others have been discovered at the different salines, numbers of which are scattered throughout this state, and that of Indiana. From Bullitt's Lick, in the former, have been taken, 
1. An enormous grinder, belonging to the Eler phas Indicus of Cuvier. This is now in my possession, and having fallen into pieces from its great agc, allows a full opportunity of examining it in the manner directed by that celebrated naturalist.

2. A thigh bone of great magnitude, probably belonging to the mastodon. A gentleman who saw the portions of this bone taken up, (for it was broken by the tools of the workmen) assured me that its cavity was filled up with a fatty matter, with which he possitively greased his shoes: Mr. Speed is the person alluded to.

3. Dr. Drake mentions a grinder, similar to one in ray possession, which was dug up from near one of the branclues of the Maumee; also, a tooth of the mastodon, found near the mouth of the Great Miami, and a joint of the back bone of one or other of these species, disinterred from the site of Cincinnati.

4. The skull of a buffaloe, with one of the horns fast in the socket, completely petrified. I was for many months very dubious, how to consider a fossil, resembling a horn of the above 
mentioned animal, which I had found in one of the streets of Jeffersonville, when accident made me acquainted with an inhabitant of that town, before whose door it was picked up. He told me that he had some time before taken out from between the first and second strata of rock in the Falls, while quarrying stone there, the entire skull of a buffaloe, with one perfect horn fixed in it. Considering this a great curiosity, he had taken it home, where, a few days after, a philosophical carpenter, by way of ascertaining its nature, struck it with a hammer, and broke both skull and horn to pieces. Vexed at the accident and thinking the fragments of no value, he threw them out into the street, where I became the possessor of the horn, (at least, a great portion of it) in the manner already described.

\section{AN'TIQUI'TIES.}

'The antiquities of the western country in general, liave been already so minutely de- 
scribed by others, that I shall no doubt be readily excused for the brevity of the present article, and the more so, as there is nothing of the kind peculiarly interesting in the immediate vicinity of Louisville.

Mounds or tumuli are-occasionally met with, some of which have been opened; nothing, however, was found to repay the trouble of the search, but a few human bones, mixed with others apparently belonging to the deer.

With respect to the uses of these accumulations, there can be no doubt; their contents speak plainly on the subject, and from the circumstance of some of them having been found to contain but one skeleton, while from others, of not more than equal magnitude, the remains of twenty have been disinterred, we may reasonably conclude, that the former were designed for the mausolea of chiefs, or distinguished persons, the latter for those of the community.

Hatchets of stone, pestles or grain beaters, of the same material, arrow heads, of flint, together with the remains of hearths, indicated by flat stones surrounded by, and partly covered with, broken shells, fragments of bones, char- 
coal, calcined earth, \&c. are every where to be seen, and some of them in situations affording an ample fund for speculation to the geognost. Two of the first mentioned insiruments were discovered, a few miles below the town, at the depth of forty feet, ncar an Indian hearth, on which, among other vestiges of a fire, were found two charred brands, evidently the extremities of a stick that had been consumed in the middle, on this identical spot: the whole of this plain, as we before observed, is alluvial, and this fact shews to what depth that formation extends. But at the time the owners of these hatchets were seated by this fire, where, I would ask, was the Ohio? Certainly not in its present bed, for these remains are below its level; and where else it may have been, I am at a loss even to conjecture, as there are no marks of any obsolete water course whatever, between the river and Silver Creek hills, on the one side, and between it and the Knobs, on the other.

Not many years past, an iron hatchet was found in a situation equally singular. A tree of immense size, whose roots extended thirty or 
forty feet each way, was obliged to be fclled, and the earth on which it grew to be removed, in order to afford room for a wall connected with the foundations of the great mill, at Shippingport. A few feet below the surface, and directly under the centre of the trec, which was at least six feet in diameter, was found the article in question, which, as was evident upon cxamination, laad been formed out of a flat bar of wrought iron, heated in the fire to redness, and bent double, leaving a round hole at the joint for the reception of a handle, the tro cnds being nicely welded together, terminated by a cutting edgec.

Many others of a similar description have been found at different times and places, but as they were always attributed to the settlers of Kentucky, subsequent to 1769 , no care was taken to note such local circumstances as might have determined a greater antiquity; and the one above mentioned would have, no doubt, shared the same fate, but for this obvious fact, that the tree must necessarily have grown over the axe previously deposited there, and that no luman power could have placed it in the par- 
ticular position in which it was found, after that event had taken place. The trec was upwards of two hundred years old.

A little below Clarksville, immediatciy on the bank of the river, is the site of a wigwam, covered with an alluvial deposition of earth, six feet in depth. Interspersed among the learths, and scattered in the soil beyond them, are large quantities of human bones, in a very advanced stage of decomposition. Facts most generally speak for themselves, and this one, tells a very simple and probable tale. The village must have been surprised by an enemy, many of whose bodies, mixed with those of the inhabitants, were left upon the spot. Had it been a common burial place, something like regularity would have been evinced in the disposition of the skeletons; neither should ive have found them in the same plane, with the fire places of an extensive settlement, (or near it) but below it.

That walls, constructed of bricks and hewn stones, have been discovered in the western country, is a fact as clear as that the sun shines when he is in his meridian splendor, the dog- 
matical assertions of writers to the contrary, notwithstanding. Among the great variety of the latter, I shall name but one, which I have selected, becausc, the gentlcman who is my authority for the story, is now in this town, was himself on the spot, and is one on whose simple word the most implicit reliance may be placed: Mr. R. W. Todd assures me, that he was prescnt, during the year 1809, where some workmen were employed in sinking a well on Todd's Fork, a branch of the Little Miami. At the deptis of eighteen or twenty feet, they came to the stump of a tree and a grape vine, and, lower down, to a wall, regularly constructed of hewn stone. Having dug a few feet along the side of this, their spades, \&c. ivere arrested by a pavencut composed of the same materials. They had but little time to comment on this discovery, for the water rushed in and obliged them to ascend so speedily, that they could hardly loosen one of the stones from the wall, which, however, they accomplished, and brought it up with them. Mr. Todd examined the stone attentively, and declares it to have been a piece of a silicious limestone rock, of a regular ob- 
long figure, evidently fushioned by some iron instriment.

With respect to the existence of the former, Mr. Savage, of this place, has lately made a cliscovery, that puts the fact beyond a possibility of doubt, and one that tends to throw mucin light upon the race of people now supposed extinet, that once inhabited the vallies of the Mlississippi and Ohio.

This gentleman; fatigued by the continual ennui of his situation, the natural consequence of his confinement to the Buffaloe steam bont, which, from accidents happening to her machinery, rumning aground, \&e. was detained a long time in the Mississippi, determined upon an cxcursion to the shores of the river, where acc:dent directed his steps to the ruins of a fortined town of considerable extent, near the River St. Francis; among which were still standing, part of the walls of a citadel, built of bricks cemented $b_{z}$ mortar.

Over these walls were spread, the extended branches of a number of gigantic trees, which grew upon them. To ascertain the age of the largest of these, was a point of primary impor- 
tance, to fell them, no easy task; perseverance, however, soon accomplished, what curiosity had commenced, and several of them were levelled with the earth, when it was found, from the number of annual rings visible on the surface of the stumps, that they must have stood there, at least, three hundred years! which furnishes a hint, respecting the probable time in which the town became a ruin. The bricks (several of which are now in this place) are composed of clay, mixed with chopped and twisted straw, of regular figures, hardened by the action of fire, or the sun. It is a.subject of deep regret to me, that I am only able to furnish this very lame and imperfect account of one of the most interesting discoveries, respecting the arts of the ancient inhabitants of America, that has ever been made; but the public will probably be the gainer, as Mr. Savage himself contemplates, 'ere long, laying before it every circumstance connected with this curious fact. I cannot, however, take leave of the subject without observing, that had common attention, and but a small portion of curiosity existed in the minds of the carlier settlers of Kentucky, and in those of the 
western country generally, we should, no doubt, at the present moment, possess a sufficient mass of evidence to enable us to decide, most possitively, on the nation or origin of that race of men, who have left behind them narks of civilization and refinement, that serve to distinguish them from the more savage inhabitants of the forest. 


\section{SETTLEMENT.}

CHAPTER III.

BUT few settlements, in any portion of the known world, have ever been effected under so many discouraging circumstances, as that of Louisville and its adjacent country. The great bone of contention, between the northern and southern tribes of Indians, who disputed the possession of it with each other for a hunting ground, it was not likely they could see a foreign people step in between them, and take possession of it, without a violent struggle, on their part to prevent it.

Man, in his natural and savage state, is by far the most remorseless and cruel animal of the creation, surpassing the tiger in ferocity, and incapable of forgiving an injury, however unintentionally it may have been offered to him. No matter what length of time may have elapsed, from the moment in which it is committed; no matter what motives may have palliated, $\mathrm{ex}$ - 
cused, or justifred the deed-nothing, no, not the silence of the tomb, can protect the object of his hatred; he must have blood! and, of default of the offender, by a refinement in cruelty, making revenge to reach beyond the grave, he wieaks it on his defericeless widow or helpless children !

Such were the people, among whom the daring settlers of Kentucky first pitched their tents, in 1769. No sooner did they appear among the tawny sons of the forests, than the war-whoop was heard, the hell-hounds of death were let loose, and murder stalked triumphantly abroad. Every sum that rose witnessed some work of destruction; every wind that blew, wafted on its wings the heart-appalling yells of an infernal pack, fresh from their butcher chace; and that dust, which had before oft imbibed the blood of the savage, now became saturated with that of his civilized brother.

The fury of an ever-active and wary foe, was not the only danger that threatened extermination to those few brave spirits who ventured to this land of blood; Disease reared her pale

t The name by which Kentucky at first was designated. 
and spectre form among them: so that many escaped, unhurt, the hatchet and the kmife, only to receive their doom from her fell influence.

Hunted and watched by the natives, like the beasts of the forest; depending upon their rifles for their support, the pursuit of which forced them into the toils; their bodies enervated by sickness, and their minds cnfeebled by the continual apprehension of danger; deprived of all medicine or medical aid-it is not to be wondered at, that so few were added to their number, that a settlement, so situated, progressed but slowly.

From an attentive consideration of the various reliques of the western country, I am led to believe however, that several hundred years previous to the epoch, the shores of the Ohio and Mississippi, were inhabited by a race of men instructed by, and descended from Europeans, (probably the French,) who were the authors of all those more perfect specimens of human art alluded to. Whether we consider the iron hatchets, and other manufactured pieces of that metal, which, at different times and places, have been found buried in the earth, in situa- 
tions indicative of their great antiquity, or whether we reflect upon the cxistence and composition of the bricks taken from the crumbling wails of the lateiy discovered ruins on the Mississippi, we are equally certain that neither tic Mexicans, nor any other nation of cither North or South America, could have been the manufacturers.

The use of iron was unknown among them, until after the year 1519, which, according to the principle assumed,* by which we have calculated the lapse of time, since those instrilments were buried, and these walls constructed, is about the period in which the latter were abandoned.

To some other quarter, then, we must look for an explanation of these bricis, iron hatchets, hewn stones, and regularly constructed fortifications, the three latter of which are so commonly dispersed throughout the western country. To attribute them to the Egyptians, Phoeniceans, or any of the elder nations of Asia, would be as ridiculous, as to suppose them the work of the native, uncivilized American In* See chap. Antiquities. 
dian, and it is cvident, from the great age ${ }^{*}$ of the timber often found growing on the embankments, that they must have becn constructed at or prior to the discovery of St. Salvador, by Columbus, in 1492.

Greenland was said to have been visited by the Icelanders and the Norweigians, in 982, and a colony planted by the former in Vinland, a part of Labrador, or Newfoundland, in 1003. From this epoch until the discovery of St. Salvador, in 1492 , intervenes a period of four hundred and ninety years, during which time, history makes no mention of any attempt at further discoveries; all remarks, therefore, relative to what may have passed during this interim, are purely conjcctural; but upon the discovery of sucl a conntry as Greenland was represented to be, by Eric-raude, and particularly when, in a few years after, we sec the same people, who, by his persuasion, were induced to follow him thither, extending that discovery to Vinland, we are a little surprised that the flame which hitherto had animated them, should be smothered in their bosoms, at the verw moment they 
began to reap the reward of their cnterprise in the possession of a country far superior to their own.

But even admitting that the Danes, Icelanders, or Norweigians, never rentured in the track, which finally guided Columbus to the American coast, are we sure that accident or design, the spirit of enterprise or stress of weather, may not have led individuals of other nations to the same spot?

Europe long rang with the noise of the discovery of Newfoundland; and although the first expedition by the French, fitted out with a view to similar purposes, by the imperial order, was in $152 \%$, yet such is the cnthusiasn with which that peoplc engaged in the pursuit of every thing that is novel or uncommon, I think it not unreasonable to suppose, that, stimulated by the hope of gain, and the desire of distinction, or, perhaps, disgusted with their country or its government, and desirous of secking new ones, some few individuals, without parade or noise, leaving the soil of France, long prior to the expedition of 1524, and trusting to their fortune,

- Giovani Verazzoni visited America, in 15:4, by order of Francis I. 
may have been conducted safely to the forests of America; where, finding a country, lovely beyond description, abounding with every gift that naturc can bestow, and delighted with the uncontrolled exercise of man's natural heritage of unlimited freedom, they determined to remain forever, incorporating themselves with some friendly tribe of Indians, and communicating to them the knowledge of such arts as would tend to their. comfort and security.

Whatever proof may be wanting, to establish the time or mode in which these adventurers became the inhabitants of the forest, of their uation, or that of the people who were the constructors of the town lately discovered on the Mississippi, there exists much positive and specific evidence in the bricks of which the walls are composed. As early as the latter end of the ninth, and the beginning of the tenth century, the inhabitants of Anjou were in the habit of building their houses with clay, well tempered and thoroughly mixed with chopped or twisted straw, in which state it was termed pizay, and when divided into pieces of regular and determinate figures, and dried in the sun or 
by fre, assumed the name of bricks. 'This practice, I belicre, subsequently extended to Picardy and several other provines of France, where the custom, I have no doubt, in a great measure still exists. The similarity betwecu this substance and that of which the ancient bricks (if they may be so called) are composed, is striking-they are, in fact, one and the same. When, in addition to this circumstance, we take into consideration, the facility with which the French are known to mingle with the Indians of this country, adopting their dress, manners, mode of living, \&c. together with the existence of walls now buricd in the earth, whose stones have evidently been cut by some metallic instrument, and, above all, when we find one of those instruments* lying immediately under the centre of an inmense tree, whose roots covered a circle of forty feet in dianeter, we cannot hesitate to acknowledge, that some persons acquainted with the art of working metals, and the uses to which they may be applied, possessing a tolerable notion of the comforts of life, and the best possible mode of screening them- 
selves from the "peltings of the pitiless storm," as well as the peltings of their more pitiless enemies, could alone have been the workmen; that the aborigines of Amcrica, possessing no knowledge of these things, until after their acquaintance with Europeans, could of themselves never have produced them; and, finally, that of all the nations of Europe, who might have had a hand in their formation, facts are in favor of the French.

If, then, there once existed in this country a people so far advanced in the arts of civilized life, as these relics indisputably prove to have been the case, the question very naturally arises of, What has become of them? this is not so easily answered. They may have been all destroyed at one fell swoop by war, pestilence, or famine, singly, or united. If my supposition respecting the introduction of Europeans among them be admitted, it will furnish a clew, which may enable us to thread the labrinth, and to account at once for the disappearance of those people, and the origin of the white Indians.

Incorporated, as I have previously, supposed, 
with one particular, or several friendly tribes, to whom they taught the art of fortifying themselves in the field, and the superior modes of warfare as then practised in Euv'se, as wcll as of the great importance of iron, in the surous uses to which it may be applied, thereby enabling them to be superior to their neighbours, in peace as well as war, gratitude to the authors of such signal services, may have induced those tribes to have clothed them with power and command, privilegio synocei.

Hence arose a race of light complexioned men, distinguished from their savage brethren, not more by a difference of colour, than by a refinement of intellect, and a knowledge of the arts. Superiority is always envied. Disturbances were excited between these tribes, and those who remained in a perfectly savage state; wars ensued and battles were fought, in which the white Indians and their allies necessarily proved successful, as, in addition to an equal portion of bodily courage and address with their antagonists, they were acquainted with the art of war, which taught them the utility of raising those more perfect spccimens of fortifications, 
which have oflate exeicised the pens of -so many ingenious writers.

Perceiving the great and decided advantages resulting from the mode in which their enemies carried on the war, a morle that enabled a handful of resolute men to resist an army, and having acquired some little knowledge by woeful experience, the black Indians hastened to imitate them, throwing up the earth and forming breast-works, behind which they could fight, retire for shelter when too hard pressed, and within whose limits they would be secure from a nocturnal surprise, producing a series of works similar to the former, but inferior in point of execution. Having made this approximation to an equality with their foes, superior numbers, combised with accident, may have turned the scales of victory, and gradually put the hitherto triumphant party in the power of their mortal enemies: extermination was the word, and thus the white Indians with the arts they cultivated, forever disappeared.

About the time when gencral Clarke first visited this country, an old Indian is said to have assured him, that there was a tradition to this 
efiect-that there had formerly existed a race of Indians whose complexion was much lighter than that of the other natives, which caused them to be known by the name of the white Indians; that bloody wars had always been waged between the two, but that at last the black Indians got the better of the others in a great battle fought at Clarksville, wherein all the latter were assembled; that the remnant of their army took refuge in Sandy Island, whither their successful and implacable enemies followed and put every individual to death." How true this may be I know not; but appearances are strongly in its favor. A large field a little below Clarksville* contains immense quantities of human bones, whose decomposed state anc the irregular manner in which they arc scattered, as well as the circumstance of their being covered with an alluvial deposition of earth, six or. seven feet deep, evidently prove that it was not a regular burial place, but a field of battle, in some former century. Relies of a similar description are said to have been seen in great plenty on Sandy Island, in 1778, none of 
which, however, are visible at this day, (upon the surface) which may be owing to the constant deposition of sand upon the island, and the action of the water in high floods, whose attrition may have finally removed every vestige of such substances.

To return, however, from this digression, to the more immediate settlement of Kentucky, the first person who visited it, of whom we have any account, was James M'Bride, who travelled through it, in 1754. In 176\%, John Findley, an Indian trader, on his return to North Carolina, depicted the fertility of its soil in such glowing colours, to colonel Daniel Boon, as induced the latter, in 1769, accompanied by said Findley and others, to venture thither. Disastrous was the result of their expedition: with the exception of Boon, who remained a solitary inhabitant of the woods, until 17\%1, when he returned, they were all plundered, dispersed, and killed by the Indians.

In 1779, Boon, whose daring soul was undismayed at the fate that had befallen his companions, and reckless of the hardships he himself had suffered, (hardships which many a " gayer crest" would scarcely have ventured to encoun. 
ter,) with all his family, and forty men from Powell's Valley, again braved the terrors of the wilderness, penetrated to the banks of the Kentucky River, and erected thercon somic cabins, naming the place Boonsborough.

In the spring of 1778 , general George Rogers Clark*, acting under the authority of the legislature of Virginia; descended the Ohio, with a detachment of three hundred men, a military force destined to the reduction of Kaskaskia, Cahokias, and Vincennes, the then British possessions. In order to deceive the enemy, the general landed his troops at an island opposite the present town of Louisville, and had the ground cleared, in order to enable six families, $\uparrow$ who accompanied the expedition, to plant corn thereon, which they did, in the same year; thus

* This great man is now no more ! He expired on the 13th of February, 1s18, in the sixty-sixth year of his age, descending to the toinb of his forefathers full of years and glory, beloved and respected by all who knew him, not less for the amiable qualities of his heart and the soundness of his judgment, than for the important services he rendered to this country. Eagle-eyed in his pcrceptions, quick as thought in his decisions, once determined, he never reccded. Entertaining the most high and chivalric jdeas of partiotism and honor, at their shrine he sacrificed his blood and property. Though no stately column or sculptured marble mark the spot where he reposes, yet is his name emblazoned in the scroll of Fame, and his memory embalmed in the hearts of his countrymen, who may with truth exclaim, to the enguiring admirers of departed greatness, "Si queris monumentum circumspice!"

+ James Patton,

Rd. Chenowith,

John Tuel,

Wm. Faith,

J. M'Manness,

$* * \rightarrow * *$ ? 
with a feigned view of settling the country, allaying any suspicion that may have arisen in the minds of the enemy, with respect to his ultimate object.

The detachment, headed by its enterprising leader, then proceeded on its march, leaving behind them the aforesaid families, who, in the fall of 1778 , removed to the main land, immediately opposite the island, at a place now.called White Home, where they erected their cabins. An addition was made to their numbers in the spring of 1779, by the arrival of a few emigrants from Virginia, who seated themselves adjoining: and a little below them.

In the fall of the year 1779; the government of Virginia opened an office for the sale of her lands situated on the western waters south-east of the Ohio and north of Green Rivers, confirming the military surveys, made previously to 1778, on warrants granted by virtue of his Britannic Majesty's proclamation of 1763, also granting settlements and pre-emptions for lands, selling the remainder of that which was vacant, at forty pounds per hundred, receiving in payment her paper money, which was not worth 
nore than one shilling specie in the pounch This occasioned a very considerable influx of adventurers who settled throughout the country, in statious or forts, so called from their being compelled to arrange their cabins in such a way as would serve for the purposes of defence, in case of an attack from the Indians.

At this period there were but two avenues to Kentucky; the one led through the wilderness, the other down the Ohio. Those persons who came by the first road, seated themselves in the vicinty of Logan's Station, Harrodsburg, Boonsborough, and Lexington, and many of those who descended the river, landed at Limestone, and pursued their way to Lexingten; others, however, not intimidated by the reports of the sickness prevalent at Louisville, and of the murders committed on its settlers, continued on to that place. In the fall of 1779 and spring of 1780 , seven different stations were settled on Beargrass, and during the latter year Boon's Station, near Shelbyville, was formed, with several others in the interior, and, thus was laid the foundation of this at present great and flourishing Entrepot of the west. 


\section{PROPRIETORS.}

TWO thousand acres of the plain before mentioned, on which Louisville is built, including the sites of Portland and Shippingport; situated in the county of Fincastle, were patented on the 16th of December, 1773, in the name of Joln Connelly, a surgeon's mate, in the general hospital of the royal forces, by virtue of his Britannic Majesty's proclamation of 1763.

In 1775, Connelly conveyed an undivided moiety of this tract, to colonel John Campbell and pursuant to the aforesaid proclamation, two thousand acres, adjoining and below Connelly's were patented the 16th December, 1773, in the name of Charles de Warrenstaff, or Warrendorff, an ensign in the (royal) Pennsylvania regiment.

In 1774, Warrenstaff conveyed this tract to Connelly and Campbell, by whom the four thousand acres were partitioned in such a way, that the upper and lower thousand fell to the share of Connelly, when, in 1780, owing to the latter having previously joined the cause of his royal master, the upper thousand acres were escheat- 
ed, and Louisville established thereon, by an act of the legislature of Virginia. In 1778, Connelly conveyed his lower thousand acres to John Campbell, who devised all his land within five miles of Beargrass, to Allen Campbell.

\section{PLAN.}

Louisville was first laid out in 1780 , by William Pope. A new survey was subsequently made by William Peyton, assisted by Daniel Sullivan, who plotted the out lots; none of these surveys, however, or any papers belonging to them are to be found at this day, owing to some unaccountable negligence or sinister intentions, they have been destroyed, a circumstance that has been productive of much dispute and litigation with respect to boundaries. The only plat deposited among the public archives, is that adopted in 1812, according to a survey of Jared Brookes, which is precisely the half of the two thousand acres granted to Connelly, the division line being run by Daniel Sullivan, on the 20th of July, 1784 .

The out courses of this survey are from, 35 poles above the mouth of Beargrass Creek. 
on the bank of the Ohio river, S. 83, W. 35 poles to the mouth of the creek, thence N. 87, W. 120 poles, N. 50, W. 110 poles to a heap of stones and a square loole cut in the flat rock, thence (the division line) S. 83, E. 769 to a white oak, poplar, and beech, N. 37, W. 390 to the beginning, no variation. Main, Market, and Jefferson streets, ${ }^{*}$ which run nearly E. and W. are each ninety feet wide, all others sixty, except Water street, which is but thirty.

The different squares formed by the intersection of these streets, are divided into half acre lots, as far as Green street, but those of the extension south of that, are laid off in five, ten, and twenty acres, through which the cross streets are to be continued as they may be wanted. Although the lots north of the extension are said to be half acre ones, they all exceed it, as will appear by the following statement: those between Water and Main streets, measure 210 feet by 105, exceeding half all acre by 270 square feet, between Main and Market streets,

* The names of the principal streets, running in that direction, are Water, Miain, Market, Jefferson, Green, Walnut, and South. These are all intersected by twelve others, sixty feet wide, that are named First, Second, Third, \&c. commencing at the eastern extremity of the city, and continuing regularly west to Twelfth street, which is the last, 
211 by 105 , exceeding it by 375 square feet, between Market and Jefferson 210 feet 10 inches by 105 , exceeding it by 375 1-2 square feet, and between Jefferson and Green streets 210 by 205 , exceeding it by 270 square feet.

A slip, 180 feet wide, south of the Jefferson strect range of lots, extending the whole length of the town, had been reserved for a common, which the trustees subsequently had laid off in lots, and, with the exception of a strip, sixty feet wide, (Green street,) caused to be sold. Whether this sale be valid or not, the law must hereafter determine, as the question will most certainly be agitated, it being a matter of moment to the public in general, which is deeply interested, not merely as regards the actual loss sustained by it, in the deprivation of this property, but on account of the stretch and usurpation of power in the trustees, which occasioned it: they had no more authority to sell that slip, than they had to expose to public auction the persons of the citizens, and knock them down to the lighest bidder. The public is collectively an individual, and the property of an individual is, or ought to be, as sacred as his person. 
Two great faults in the plan of this town, must be evident to the most superficial observcr. The one is a want of alleys, the other that of public squares. With respect to the first, much inconvenience is already the consequence, and what that will increase to when the population will amount to 20,000 souls, (a period not far distant,) may be readily conceived. It is not yet, however, too late to correct this error, and as the sacrifice of a few fect of ground in each lot would add greatly to the present and future value of it, self-interest, will I have no doubt, soon cause it to be attempted.

The total want of public squares, is an evil of much more serious cast, and one that promises hereafter to furnish full employment to the sons of Esculapius and their suite. Rapidly as this town angments its population, a few years will find every foot of ground within its precinets covered witli houses, forming ramparts that will keep without, that ministering angel of health, a pure and circulating atmosphere, and keep within, the daemon of contagion, who draws his very existence from the foul and pestilent airs of a pent up city. 
As to the flagrant want of tastc, cxhibited in the mode of improving the banks of the river, nothing but the great value of the ground can be urged as an excuse. Had the first, or Main street, been laid off so as to have cxtended 90 feet from the brink of the second bank, forming an avenue front of the town, and had no houses been permitted to exist north of that avenue, those to the south all fronting it, and of course the river, Louisville would have exhibited a coup d'xil, surpassed, in point of beauty, by few in the world. As it is, the town has turned its' back upon the varied and interesting prospect presented by the Ohio and its Falls, here and there studded with islands, a beautiful and verdant country extending six miles beyond it, bounded by the Silver Creek hills, whose majestic tops, crowned with leafy honours of varied hues, terminate the scene.

\section{PRICES OF LOTS.}

For a length of time after the settlement of this place, lots on the principal streets were sold at from $\$ 700$ to $\$ 1,400$ each, nor did they materially increase until 1812, when the beneficial effects resulting from the estabiishment of 
a branch of the State Bank of Kentucky, in Louisville, werc immediately perceived in the increased price of real estate, lots rising to $\$ 4,000$ and $\$ 5,000$ each. Upon the location of a Branch of the United States Bank here, however, in 1817, these same lots which had previously been sold for 700 dollars each, rose to 300 dollars per foot! which has since been the average price in the best situations. Owing, however, to the pressure of the times from banks, rag-money, speculators, shavers, et id omne genus, property has lately declined in value, and will continue to do so until it sinks to a reasonable and proper level.

\section{MATERIALS FOR BUILDING.}

Limestone of an excellent quality, and inexhaustible quantities, is supplied from the rock in the bed of the river, which is so constituted, in many places, as to require neither boring nor blasting to quarry it, a simple crow bar being sufficient for that purpose. Marble of various colours is to be procured in plenty, from the banks of the Kentucky River and its tributary branches, and several millions of good bricks are annually manufactured in the various yards 
in the vicinity of the town. Lime, of a good quality, is in great abundance, consequently cheap. Timber is chiefly brought from the Allegheny mountains and the banks of the Kentucky, the former furnishing white pine, the latter red cedar, which are both brought in rafts to the Falls, and there delivered to purchasers, at a moderate price. The principal woods used by the cabinet makers are cherry and maple, which are amply supplied from the surrounding country. Mahogany, however, which is superceding the two former, since the introduction of steam boats, is freighted up the river from New Orleans, formerly it was transported in waggons over the mountains, and brought down the stream in chalons and keel boats.

\section{BUILDINGS.}

'There are at this time in Louisville, six hundred and seventy dwelling houses, principally brick ones, some of which would suffer but little by being compared with any of the most elegant private edifices of Philadelphia or New York. It was calculated pretty generally, that from 250 to 300 brick buildings ronld have been 
erected during the last summer, but such was the scarcity of money, that not more than twelve or fourteen were completed; preparations, however, are making to proceed rapidly in the business, the ensuing season, the influx of strangers being so great, that many of them can sarcely find a shelter.

\section{POPULATION.}

There are no documents by which we can ascertain the progress of the population of this place, or even determine, with certainty, what it is at present; but allowing six persons to each house, which is the usual number in similar estimates, we should have 4,020 , yet so much is the town crowded, and so condensed is its population, that we may with great safety assert, the whole amounts to 4,500 souls; so rapid is the increase of this number, that, in all probability, it will be trebled in less than ten years.

\section{STATE OF SOCIETY.}

Commercial cities of all newly settled countries, whose inhabitants are gathered from erery corner of the earth, who have migrated thither with but one single object in view, that of ac- 
quiring money, are stamped with no general character, except that of frugality, attention to business, and an inordinate attachment to money. Absorbed in the great business of adding dollar to dollar, no time is devoted to literature, or the acquirement of those graceful nothings, which, of no value in themselves, still constitute one great charm of polished society.

Such is the character of the inhabitants of this place in general, "ma ogni medaglio ha il suo reverso."*. There is a circle, small 'tis true, but within whose magic round abounds cvery pleasure that wealth, regulated by taste, can produce, or urbanity bestow. There, the "redheel" of Versailles may imagine himself in the emporium of fashion, and, whilst leading beauty through the mazes of the dance, forget that he is in the wilds of America.

The theatre, public and private balls, a sober game of whist, or the more scientific one of billiards, with an occasional re-union of friends around the festive board, constitute the principal amusements; and it is with pleasure I am able to assert, without fear of contradic- 
tion, that gaming forms no part of them. Whatever may have been the case formerly, there is hardly, at the present day, a vestige to be seen, of this ridiculous and disgraceful practice, and, if it exist at all, it is only to be found in the secret dens of midnight swindlers, within whose walls once to enter, is dishonor, infamy: and ruin. 


\title{
PUBLIC BUIIDINGS:
}

\author{
CHAPTER 1V.
}

THE Court House is generally allowed to be the landsomest structure of the kind, in the western country, and was built in 1811, after a plan drawn by John Grvathmey, Esq. It consists of a borly and two wings, all of brick, the former of which is ornamented with an Ionic portico supported by four lofty columns, and a cupola terminated by a spire. In the second story of the south wing is deposited the public library, which consists of about five hundred volumes. The remaining apartments in both wings, as well as several in the second story of the main body, serving for the various offices of the county, with the exception of the clerk's, which is held in a small brick building nearly opposite the

$$
\text { GAOr, }
$$

A most miserable edifice, in a most filthy and ruinous condition, first cousin to the black hole of Calcutta. A new and spacious one, is horverer contracted for, which will be commenced in 
a few weeks, to be built (as is the old one) of stone, with arched fire proof apartments, and cells secure, but so contrived as to afford shelter to the unfortunate victim of the law, who may there "address himself to sleep" without any fear of losing his ears, through the voracity of the rats and other vermin that swarm in the present one. It would be well to surround the new building when frished, with a high stone wall, and to inclose within its limits, that horrid looking engine, now standing opposite the Court House. I allude to the pillory and whipping post. Such things may perhaps be necessary, (and even that is very doubtful) for the punishment of the guilty, but I am sure it never came within the intention of the law, to inflict through it, pain upon the innocent, it's very appearance, combined with a knowledge of its uses, sufficing to blanch the cheek of every man, who is not through custom, or a heart callous to the sufferings of humanicy, totally regardless of such scenes.

BANKS.

Of the great number of these blessed establishments, with which the inhabitants of this 
state are favoured, Louisville may boast of three. Previously, however, to the existence of either of them, was an unincorporated one named the Louisville Bank, whose capital of 75,000 dollars, shortly after its creation, was thrown into the Branch of the state bank of Kentucky, located here in 1812, with an additional 25,000 dollars, making a capital in all of 100,000 dollars.

In 1817 a branch of the United States' Bank, after a good deal of trouble, was procured, for the accommodation of the good people of this place, many of whom, to judge from their conversation, already rue the day they invited it hither, neither do they seem much more pleased with the Commercial Bank of Louisville the last established of the three whose capital of $1,000,000$, is kept pretty much at home, but few of their notes being in circulation. This howver is the only objection to it, its paper being in as good credit as that of the United States Bank.

Without pretending to any great knowledge of banking mysteries, it is very evident, that the people of this country are ruining themselves by similar institutions, as fast as they cleverly can. It is now but fourtcen months since the last 
great accouchment at Frankfort produced a litter of forty, a promising and independent family, that were to have banished poverty and duns forever from Kentucky. Specie, it was said would always be paid on presentation of those notes, many of which at this moment will not be taken in exchange for tobacco for your pipe, without paying into the bargain a small discount of from ten to fifty per cent. and others again, which are of no use but to light that tobacco when you have got it. 'This, as may be supposed, affords fine sport to shavers, who should strenously unite in the production of a second batch, equally numerous with the first, which, in due time, would enable them, like Silky, in the Road to Ruin "to provide for their families."

\section{SEMINARY.}

'This is a tolerably capacious brick building, under the direction of the trustees of the town, wherein are taught the several branches of a regular and classical education. 'This institution is not, I am sorry to say, so well patronized as it deserves, the clamours of Phutus 
drowning the modest accents of the muses, whose invitation to repair thither is selctom heard, and still seldomer accepted. 'This eter-' nal hunger and thirst after money, to the exclision of almost every other pursuit, is not; however, peculiar to the inhabitants of this place, but a gencral trait in the character of all newly formed commercial citics, where, as soon as a boy can read, write, and cast up a bill, he is withdrawn from school and placed at a desk, there to be initiated into the mysteries of buying and selling. To know how to make money is the grand object, if he knows that, he knows cvery thing, that needs to be learned, all else is deemed superfuous, and were the arts and sciences to appear in the streets, in the persons of Phidas or Aristetle, Canova or Newton, clothed in the garb of poverty, they would be jostled into the kennel. "Que Ciceron se presente mal habille, Ciceron sera recu comme un cuistre."

CHURCHES.

'There are but three churches, one for the methodists, a sccond for the catloolics, and a third for the presbyterians, neither of which are re- 
markable for their appearance, with the exception of the latter, which is a neat, plain and spacious building, on which a steeple is about to be erected. It is furnished with galleries and an organ loft, the interior being divided into pews, intersected by three aisles, and upon the whole, though no chef d'auvre of architectural design, it reflects much credit upon the place.

\section{THEATRE.}

A handsome brick building, of three stories. Until the summer of 1818 , it was but little better than a barn; at that time, however, it underwent considerable alterations, and is now fitted up with a degree of taste, that does honor to its manager, Mr. Drake, whose unceasing endeavours, to merit the approbation of the public, will no doubt meet with a liberal recompence, in its patronage. The house is divided into a pit, two tiers of boxes, and a gallery, capable of containing in all about eight hundred persons. Attached to the premises are a retiring room for the ladies, and one containing refreshments for the company in general. 


\section{A NUFACTORIES.}

HOPE DISTILLERY.

Some time during the year 1816, a company was formed in New England, and who subsequently obtained an act of incorporation from the legislature of this state, under the name and by the title of the Hope Distillery Company, for the purpose of establishing an extensive distillery in this town, with a capital of one hundred dred thousand dollars, and liberty of increasing it to double that amount. Having purchased a lot of ground of 100 acres at the lower end of Main strcet, and immediately opposite the commencement of the Portland and Shippingport turnpike roads, they proceeded to erect thereon buildings, calculated to carry on the work in a nuch more extensive mode than any hitherto established in the United States, and according to the European method, combining the advantages of economy and a superior quality of spirit to that generally produced in this country.

Without inspection, no adequate idea can be entertained of the extent of the buildings and 
of the size and number of the utensils they contain. The grain is hoisted from the waggons into the upper story, is gromel, (if corn, with the cob,) and is again elevated over the mashing kieve; the water being pumped to the same icvel, is there heated by stcam, after which they both fall into the kieve, where they are worked by the same power, and this part of the process, which, in the ordinary way, would occupy thirty men, is performed in one hour by one man. In this lieve the saccharine matter is set at liberty, and the liquor passed of in pipes, (ruming over a gallery that comects the two buildings:) into extensive coolers, siruated in the second story of another house; when its temperature is sufficiently lowered, it is let down into large fermenting vessels, that (immediately maler the coolers) compand the stills, which are in a separate builling.

The spinit, when made, passes off into large reservoirs under gromnd, whenee it is pumped up as ranted, and the mucilaginous and husky parts of the grain being separated in the mashing kicre, prevents the danger of burning in the still, which occasions that disagrecable and $\mathrm{cm}$ - 
pyreumatic flavour so common in our domestic spirits.

The singling still is flat, and erected on an entirely new principle. It contains fifteen hundred gallons, which boil in about twenty minutes, the doubler, being deeper; but not so large by one half the contents of the former, running off a charge in an hour. The copper used in these two stills; and their worms, exceeds ten tons in weight, was imported, from England in pieces, and put up on the spot. 'The refrigeratory is the largest vessel of the kind in America, it containing eighty thousand gallons; the works generally being calculated to produce twelve hundred gallons per day, which operation, in this climate, can be continued without interruption, summer and winter. A malthouse is atiached to the establishment, a certain portiont of the grain undergoing this process beforc the saccharum is extracted, the residuum of the whole operation furnishing an exccllent food sufficient for five thousand hogs,

* Containing 750 gallons.

$\dagger$ These are the words of the gentleman, to whose politeness I am indebted for the preceding details, but the idea conveyed, that only part of the grain is malted, is erroneous, the whole of it undergoing that process, which is absolutely required in brewing as well as distilling, to extricate the sugar or saccljarum (the principal agent in vinous fermentation) that is contained in the starch. 
which is the number calculated on by the com* pany, as soon as the works can be put into full operation.

The advantages resulting from such an $\mathrm{ex}=$ tensive concern at the point, will be readily perceived, as no one section of country alone could be relied on for a supply of grain, to keep it in constant employment, it is here enabled to command the grain countries of the Ohio, Kentucky, Sciota, and Miami Rivers, with those of their innumerable tributary streams, from all of which places it may be quickly and easily transported to the Falls. Again, this is, and must continue to be the great western mart for whiskey, as a sufficicnt supply can be kept in the New Orleans market, at the same price with that manufactured there, the difference of freight only.excepted, and having the advantage of the latter, by the markets of all the rapidly settling countries of Indiana, Illinois, Missouri, and Mississippi, the military posts and Indian trade therein established and carried on, requiring annually, incredible quantities of this demoralizing beverage. My feeble voice can be but of little utility, in preventing the erection of such 
gigantic rescrvoirs of this damning drink! I eannot, however, conclude the subject without hinting to those instrumcntal thereto, that they are incre manufacturcrs of poison for the human race, by no means slow in its operation, and so much the more dangerous as it is enticing.-But, alas! of what avail are the reasonings of the philanthropist, or the entreaties of humanity, in opposition to the commands of interest? They are as chaff before the whirlwind.

\section{AIR FOUNDRY AND STEAM ENGINE FACTORY.}

This establishment forms a prominent feature among the manufactories of Louisville, and is owned by Messrs. Prentice and Bakewell. It consists of an iron foundry, and the different shops necessary for making steam engines. The casting of iron was commenced in this place by Paul Skidmore, in 1812. In 1814 or 1815 he sold the premises to Mr. Joshua Headington, who continued to carry on the foundry and the making of all sorts of blacksmiths' work, until the fall of 1816, when he sold the concern to Mr. David Prentice, who began in January, 1817, six months subsequent to which he was 
joined in the business by Mr. Thomas Bakewell. Since that time, by the united skill of these gentlemen in their respective departments, . much more work has been produced than people are aware of, and the town benefitted in a degree that is but little known. During the last twelve months, there have been made and fitted up at their factory, eight engines for steam boats, and two for land manufactories, equal to 100,000 dollars, besides castings to the amount of 25,000 dollars, the greater part of which were used as materials for their own engines, and castings for the neighbouring county, of the vaiue of 5,000 dollars. They are under contract to deliver engines and steam boats, in the ensuing six months, to the amount of 70,000 dollars, and which, from the number of hands employed, they will be enabled to comply with. There are employed in the different shops, about sixty workmen, whose wages are 600 dollars per week, all of which is, of course, immediately spent in the town. From a rule they have adopted of dismissing every one that is drunken or worthless in any way, they can exhibit a set of men, who, by their decency of deportment. 
form a striking contrast to those of many similar establishnents.

\section{SUGAR REFINERY.}

These works are owned and carried on by Jlessrs. Maltz and Jacobsen, and went into operation some time in May, 1818. They at. present produce about three hundred loaves of sugar per day, that average five pounds each, equal to fifteen hundred pounds of refined sugar that is made in the twenty-four hours. There is nothing worthy of any particular notice in the manufactory, if we except the simplicity and economy which pervades it. The proprietors contemplate erecting a new and spacious building to carry on the work in a very cxtensive and superior manner; and as it is doubtless the interest of the merchant here to purchase of them instead of sending to the eastward for it, thereby saving, not only the freight of the barrels in which it is contained, but also six or seven per cent. in the exchange of money, there is no doubt but they will be perfectly secure in so doing. 
SOAP AND CANDLE MANUFACTORY.

This is the largest establishment of the kind in the western country, being capable of producing twelve thousand pounds of soap per week, and a thousand pounds of candles per day. It is owned by Peterson and Co:

\section{TOBACCO MANUFACTORIES.}

There are several concerns of this description, two of which are employed in preparing strips for foreign markets, the others make cigars, snuff, and chewing tobacco, the amount of business done by them all, being equal to eighty thousand dollars per annum.

\section{STEAM MANUFACTURING MILL.}

This is a solid and handsome brick edifice, five stories high, situated on Jefferson street, and owned by John H. Clarke and Co. The engine, with the exception of the condenser, is of Evans' Patent, and an cxtremely good one, moving four pair of burrs, which average eighty barrels of flour per day.

UPPER STEAM SAW MILL

Is directly in front of the former, with similar machinery, of not quite so much power, tliat 
drives two saws, and one pair of stones for the grinding of corn. The works are all upon the newest plan, the logs being drawn up into the mill by steam power. This building was erected in 1812, by Messrs. Hugonin and Swing, and by them sold to its present possessor, Mr. Tunstall. The product of one saw has been accurately ascertained by the latter of the former owners, and found to equal 1,400 feet in eight working hours, or 175 per hour, giving 2,800 feet per day for the joint product of the two.

$$
\text { LOWER STEAM SAW MILL. }
$$

This is a new building, belonging to the establishment of Messrs. Prentice and Bakewell. It is situated close to the river; immediately in front of an extensive shop lately erected by the same gentlemen, for the manufacture of steam boilers, \&c. It is nearly finished, is to run two saws, and from the intended excellence of the engine, and the style in which the other works will be constructed, it must undoubtedly rival, if not surpass the old one.

\section{MARKET HOUSE}

Is a neat structure, kept in good order, and well supplied, two days in the week, with every 
thing that can be desired in a similar place. There is, however, no great variety of vegetables, which is owing to the want of proper gardening establishments, a few of which, well conducted, would yicld a great revenue to any persons who would engage in them. Fish, of which there are abundance in the river, of a most delicious flavour, are seldom to be had, for want of fishermen; and wild fowl, geese, ducks, brant, \&c. which abound in the neighbourbood of the Falls, are rarely presented for sale, as there is not a single person who makes it his business to procure them. Beef and mutton is in great plenty, equal in quality to any of the eastern states. Venison is common, and extremely cheap, fifty cents being the usual price of a ham, weighing from fifteen to twenty-five pounds Pork, veal, poultry, including turkies, -wild and tame, rabbits, squirrels, \&c. arc common; in fine, althongh not quite equal to that of Philadelphia, it contains all the necessaries and many of the luxuries of a good market; and with respect to fruit, it is perhaps unequalled by any in the United States. Peaches of great sizc and beauty, such as bring six and a half 
cents each in the Philadelphia market, are sold here for fifty cents per bushel, inferior ones in proportion. Apples, without exception, the finest I have ever seen, are sold at the same price in the fall, and at two dollars per barrel in the winter. European grapes, melons of various kinds, cherries, raspberries, and strawberries, are to be had in their respective seasons.

\section{RECAPITULATION AND ADDITIONS.}

There are at this moment, in Louisville, three banks,

Thirty-six wholesale and retail stores, (threc more now building, )

Fourteen wholesale and commission stores, three. book stores,

Three printing offices, three drug stores, (two of these extensive,).

One nail factory, twenty-eight groceries, two confectioner's' shops,

Two hotels, conducted in a very superior style, Four good taverns, six bake houses, ten blacksmiths' shops,

Six saddlers and harness makers, two carriage maker's, 
Eight tailors, one silver plater, one gunsmith, ten cabinet makers,

Three watch makers and jewellers; three fancy and plain chair makers,

One stone cutter, one upholsterer, one pottery, Four turners in wood, ivory, and metal, five latters, two hundred carpenters,

One hundred and fifty bricklayers, thirty plasterers, six boot and shoe makers,

Twelve lawyers, twenty-two physicians, one brass foundry,

Six brick yards, one air foundry and one steani engine factory,

Onc steam saw and grist mill, 1 steam saw mill, One steam manufacturing mill, two breweries, two distilleries,

Five tobacco factories, one sugar refinery, onc music repository, and another about to be established on a large scale.

\section{IVATER.}

The well water of Louisville, which is found at various depths, from sixteen to forty feet, and which is the one commonly used by the inhabitants, is extremely bad, containing, besides a considerable quantity of lime, a large portion of 
decomposed vegetable matter. The springs which break out near the river, are generally considered unwholesome, whereas, (if there be any truth in chemical analysis,) the fact is precisely the reversc.

The water of the wells, after standing a little time, becomes nauseous to the taste, and acquires a smell highly disagreeable to delicate stomachs; that of the springs, (at least of the one I have examined,) contains no limestone or other foreign matter, is pleasant to the taste, and is perfectly inodorous, its specific gravity being so near that of distilled water, that no difference could be perceived between them in several experiments instituted for that purpose, wherein were used a very accurate and delicate pair of balances.

This bad quality of the water in general use, is one great cause of a varicty of complaints, (particularly Diarrhaa,) that are so common in the summer months, and calls loudly for a remedy, which may be easily found in a steam engine and the Ohio, whose waters being extremely pure, might, with a little expense, be distributed through every part of the town, an 
arrangement which will probably take place at no very distant period.

\section{FUEL.}

Wood has hitherto been the principal and, in fact, the only article in use here for this purpose, but owing to the discovery of a large body of coal that is said to be situated between this place and Cincinnati, as well as of the same substance on silver creck, the latter will in all probability soon become in general use. Of wood-beech, sugar tree, hickory, ash, and buckeye, are the most common, the four first making excellent fires, the latter being. grood for nothing but to put them out. The average price is two dollars per load, (about three-fourths of a cord); in the winter, however, it is seldom sold under fifteen shillings or three dollars.

\section{ROADS.}

The roads leading from Louisville to the different parts of the county, will shortly be as good as cxcellent tumpikes can make them. The one to Shippingport and Portland will be finished this summer, as will a considerable 
portion of the great Lexington road that runs through Shelbyville.* The spirited prosecutioy of these great and important public works, does much credit to the companies who have the management of them, and tends greatly to enhance the value of lands in the interior, by facilitating the transportation of their products to this great mart of the whole state.

\section{POLICE}

"De mortuuis mihil nisi bonum," is an old and, perhaps; a correct maxim, but as the vital spark does not seem altogether to have abandoned the body of which we are speaking, (although many are of opinion that it has fled for ever,) the kindling breath of merited censure, publicly applied, may increase it to a flame, whose genial influence would soon be felt in the removal of those nuisances that have so long affected the health and endangered the lives of the citizens.

* This beantiful little town was laid out by Mr. Shaunon, in the fall of 1792 ? on a's agreeable ascent in the bend of Cedar Creek, thirty-six miles E. of J.ouisville, and twenty-two W. of Frankfort. The next winter, a few cabins were crected, and afternarls a stone gaol, ten feet square and eight high, the rout heing held in a cabin. From this humble beginning, Shelbrville bas fradually become a flourishing place, containing 1,250 souls, 175 , Ar:elling houses, eighteen stores, four doctors' shops, five law oflices, one printing uffice, a goot hrick court house and gaol, an academy and private school for the instruction of youth, and two neeting houses for public worship. A cotton spinning and two wool carding manufactories have been established, and are wel! aucouraged. 
The power of regulating the affairs of the town, is vested in seven trustees, who are annually chosen for that purpose. They have authority, and it is their bounden cluty, for the faithful execution of which, their truth and honor stand pledged to their fellow citizens, by the acceptance of the office, ) to levy certain taxes for the pavement of streets, removing nuisances, and every thing necessary to the good order and improvement of the place, and the health and safety of its inhabitants. No city in the United States, or, perhaps, in any part of the world, demands a more vigorous attention on the part of the police, than Louisville, and there is none that receives so small a portion of it. The number of ponds and low marshy grounds by which it is surrounded, (some of which are even contained within its bosom, the humidity of the climate, the miidness of the weather throughout the year generally, and the intensity of the heat during the summer, are all circumstances that facilitate the decomposition of animal and vegetable matter, and consequently the formation of those "foul airs," which spread around them pestilence and death. 
Have these things been attended to, or has care been taken to remove the accumulating filth of streets and byc places, as often as is necessary? Let the public answer; let it reflect upon the pond formed last summer, by the retiring waters of the Ohio, in the bottom front of the town, whose creamy mantling surface served as a "memento mori" to the alarmed and agitated stranger, and which, no doubt, was one great cause of the unusual sickliness and mortality of the season. This depot of universal mischief, this laboratory of disease, which would have disappeared before the exertions of three men, in as many hours, was unattended to for months, and would still have continued in existence, had not Hearen, in pity to our folly, dispersed it by evaporation. A watchman is a character perfectly unknown, and not a single lamp lends its cheering light to the nocturnal passenger, who consequently stands a very good chance of breaking his neck by falling into ditches, drains, and wells, which, without a barrier of any kind around them, are frequently left open for weeks and even months together. To shew the necessity of a radical reform in the police of this 
place, much more might be added, but as the subject more particularly interests those whose senses daily give them a thousand unequivocal proofs of the fact, I shall conclude by hinting to them, that it must be always thus, until they have offices's appointed by the people whose whole and sole duty it is to look after these things, and who are paid for it, or, in other words, until they procure an act of incorporation. As long as the trustees or other officers are chosen from among mercantile men, who have no other inducement to leave their own business for that of another, but the public good; so long will the town have to take care of itself: Verbum sapienti.

\section{PAUPERS.}

The rarity, I had almost said the non-existtence, of these sons of illeness or victims of misfortune in this place, and the surrounding country, is a fact which speaks more forcibly for them than it is well in the power of language to do. I have never yet seen, in the streets of Louisvillc, what is properly denominated a beggar. The only persons who approximate to that de. 
scription are an occasional cmigrant and his family, newly arrived, whose moncy has been expended in the journey; but eren then his importunity extcnds no further than a simple relation of facts, with a lequest to fumish him, not with money, to cherease the revenue of pop shops, but with a few of the indispensible necessaries of life, such as food, clothing, or mericine. Even these cases are rare, and only occur when they happen to arive in a sickly season, and are laid upon their backs "ere they can obtain that cmployment, (of which there will be always plenty,) which would obviate the necessity of similar applications. This may serve to explain the reason why as yet no regular system of poor laws has been framed. The county court annually levy certain sums for the few paupers who, from age or accident, arc incapacitated from gaining their bread, and deposit certain others in the hands of individuals, in trust, to be applied to the relief of mendicants, in the interim of their meetings. As this place, however, is rapidly augmenting its population, these indefatigable knights of the scrip, will necessarily malic therr appearance, and it is ligh time to make due 
provision for them, and to form a code of laws, which, while it enabies the civil authority to extend the open hand of charity to the really uniortunate, will, at the same time, give it the power of transplanting to the workhouse, those sturdy Lazaroni, who, like drones, would rathe: fatten upon the labour of the whole communi$t y$, than have the trouble of providing for themselves.

\section{DISEASES.}

The nature of those diseases incident to any particular spot, may be deduced with great certainty, from the climate and physical topography of the surrounding country. 'This being case, the reader will naturally suppose that bilious, remitting, and intermitting fevers must be common in this place. 'The latter, however, although they do occur in forms the most obstinate and terrible, independent of that of a malignant one, (which is almost always fatal,) yet are not so usual as is believed, many of those so called belonging to a milder grade of the preceding class. 
The most fatal complaint among adults, (exclusive of small pox, ) is a bilious remitting fever, whose symptoms are often sufficiently aggravated to entitle it to the name of yellow $f e$ ver, and unless some speedy change be made in the internal regulations of the town, and an efficient police established, in room of the nominal one existing at present, that pestilent foe may be expected to make his appearance every summer, as a native born citizen of the place. It is vain and useless to talk of establishing lazarettoes and quarantines, to prevent the importation of this fell destroyer from abroad, while we are accumulating at home, the sources whence he springs. During the months of July, August, and September, so strongly are the inhabitants of this and the adjacent towns, predisposed to this discase, by the joint influence of climate, and the miasm of marshes, and decayed and decaying vegetable and animal matter, that they may be compared to piles of combustibles, which need but the application of a single spark to rouse them into flame! Let me not be accused of alarming people unnecessarily, for I write this under a solemn conviction in my own mind, that 
unless greater attention be paid to cleanliness, in every possible way, Louisville cannot long. escape a signal visitation from this destroying angel. I have repeatedly seen sporadic cases of it, but fortunately at a time of year when there cxisted the least danger of its spreading.

Hepatic complaints, the usual sequents of badly treated intermittents, or, indeed, of any otler kind of fever, are common, accompanied with splenitis and other obstructions of the glandular system, which together anmually deprive us of some members of our society.

In 1817, the small pox ravaged the town, and alhough every cndeavour to cut short its progress by raccination and preventing all intercourse between the sick and the well, was made by the faculty, yet, from the slothful negligence of the civil authorities, it was impossible to prevent its incculating the place for each succecding yeax.

The proportion of chidren to that of adults, who are annully transported to "that boume from which no traveller retums," is as two to one. This awful difference is principally occasioned by the prevalence of cholera infantum 
and of worms. Every child is troubled with the latter more or less, which, by inducing convulsions or tabes mesenterica, destroy a great portion of them. Diarrhoca, rheumatism, cholera morbus are frequent; consumption not só much so. If to these we add those diseases that: at times occur every where, we have the list completc.

To affirm that Louisvilie is a healthy city, would be absurd, but it is much more so than the thousand tongues of fame would make us believe, and as many of the causes which prerent it from beconing perfectly so, can be removed, a few years hence may find the farorable alterations accomplished, and do away the general impression of its being the grave yard of the western country.

As no better opportunity offers than the present of touching upon a subject which certainly does not add to the credit of the place, I must be pernitted to embrace it. I allude to the want of an lospital, or dispensary, within whose walls the indigent victim of disease or accident might find relief. Not a hut or shelter of any kind is provided for him, and shonld he be destitute 
of a home, unless an individual withdraws hirt from the street, there must he perish. It can hardly be supposed that such an accident would be allowed to happen, but as the warm th of charity has of late been singularly diminished, government, the father of the people, ought not to trust any of its children to the chance, if it be in its power to prevent it. It is true, the erection of an hospital has been authorised by the legislaturc, true it is that a committee has been appointed to receive subscriptions for that purpose, and it is also true, that the paltry sum of four or five thousand dollars is the " ne plus ultra" of the charitable efforts of the community, in favor of an institution which, to be of any value, must cost, at least, forty or fifty thousand dollars. There is but one way ever to have the thing carried into effect, and that is not by solicitation, but by the imposition of a tax, either upon the town, state, or county, to be levied in such a way that every individual shall be compelled to pay according to his means. This would be the proper mode to provide a home for the houseless wanderer, whom disease or accident is hastening to the tomb, and en 
able Louisville to wipe a blot from off her scutcheon.

Upon the subject of seasoning, as it is termed, I have but one word to say, and although I am well aware of the opposition the doctrine will encounter, from those who are more clisposed to repeat mechanically, what they hear others say, than observe and reason for themselves, I have no hesitation in asserting, (in this particular place at least,) that the idea is futile and ridiculous, and cannot be defended by either reason or experience. A severc fit of sickness happenining to an emigrant immediately on his arrival, instead of affording any security from a future attack, in fact, predisposes him to it. To suppose the former, would be to conclude, that a besieged town, after suffering every injury that a battering train could inflict, would thereby be rendered more capable of resistance thereafter. Let not this phantom be relied, upon by those who arrive in this country, as a preservative from disease. Rather let them rely upon a strict attention to their diet, upon wearing flannel next their skin, upon avoiding the early morn- 
ing air and evening deros, by the moderate use of sound wine or good malt liquor, and, if possible, upon removing, for the first year or two, into the higher country, during the months of July, August, and September. 


\title{
INSURANCE COMPANI.
}

\author{
CIIAPTFR V.
}

THIS Company was incorporated by an Act of the legislature of Kentucky, dated the 31 sit. if January, 1818, under the title and by the name of the "President and Directors of the Louisville Insurance Company," with a capital of 100,000 dollars, not to be increased beyond 200,000 dollars. The stock is divided into shares of 100 dollars each, and although as yet no dividend has been declared, it will doubtless yicld a handsome per centage. The capital is reposited in the Commercial Bank of Louisville, and at the head of the Institution presidics Thomas Prathcr, Esq. one of the most wealthy citizens of the place. The great and decided adraintages resulting from an establishment of this nature in this town, are too obvious to necd a comment.

MASONIC LODGES.

There are two Blue,Lodges, and one Royal Arch Chapter, established in this place. The $\mathrm{x}$. 
most ancient of these, is Abraham's Lodge, who received its charter from the Grand Lodge of Kentucky, in 1801, the period when all the existing lodges of the State gave up their charters, which had been taken from the Grand Lodge of Virginia, in order to receive them from that of this State, whose jurisdiction they acknowlediged. Clark's Lodge, named in honor of Gencral G. R. Claik, was chartered oniy in 1817, although it had worked some time before, by virtue of a dispensation. 'The chapter received its warrant and commenced its operations in 1818. All these institutions arc in a highly flowrishing state, and the rigid attention paid by them to the conduct of their members; ensures a continuance of it, and tends to rescue from unmerited obloquy, the character of these "sous of light."

\section{PRINTING OFFICES.}

There are three of these invaluable establishments in this place; two of which issue weekly democratic papers, called the Courior and Herald, and the third, federal, published semi-weekly, termed the Louisville Pubic Advertiser, edited by S. Penn, jun. 
POST OFFICE.

Nine mails arrive iveekly at and are distributed from this office, the amount of revenue annually derived by the government from which source, is equal to $\$ 4,000$. There iș no better datum, by which we can form an estimate of the rapid increase and rising importance of Louisville, than by the augmentation of business at this establishment, which in 1808 yiclded but $\$ 529$ per annum, whereas for several years past it has averaged four thousand!!

PORT WARDENS AND SURVEYORS.

By an Act of Congress, in 1799, Louisville was declared to be a port of entry, and a collector established there, in order to prevent the clandestine importation of foreign goods, to which, previous to this epoch, there existed no impediment whatever, New Orleans being in possession of another nation. After that city and the valuable State in which it is situated, was ceded to the American government, the district of Louisville was incorporated with that of the Mississippi, by an Act of the 13th of Fe- 
bruary, 1807, and the general Custom House located at New. Orleans, which precluding the necessity of collectors in those towns situated on the waters of the Mississippi and Ohio, the office was consequently abolished, and that of surveyor's established in lieu thereof, by the said Act, which declares their functions to consist in the survey of boats constructed in their district, and the power of granting temporary licences, which are to be survendered to the Custom House at New Orleans, on the arrival of sucls boat. Whether the surveyor's' authority extends any further, is a matter that I have not been able to ascertain, but which it is requisite should be clearly and explicitly understood, in order that merchants and others may govern themselves accordingly.

Agreeably to an Act of the legislature of Kentucky, in 1818, two officers, termer Port Wardens, were appointed for the town of Louisville, and two for Shippingport, whose duty it is, when called upon, to visit and examine any boat or cargo, to see whether the one be sound and river-worthy, and whether the latter be stowed properly, so that no heavy articles be 
placed over light and brittle ones, \&c. and to grant a certificate of the same to the captain or orvner of such boat, which, in case of any dispute arising between him and the consignee, or owner of such goods, relative to damage by breakage, \&c. is ordered by the said Act, to be received as evidence in favor of the former, prima facıe. This is a highly useful law, and will serve to settle and prevent many disputes between the shippers of goods and the owners of boats. 


\section{SHIPPINGPORT.}

CHAPTER VI.

THIS important place is situated two miles below Louisville, immediately at the foot of the rapids, being built upon the beautiful plain or bottom which commences at the mouth of Bcar Grass Creek, through which, under the brow of the second bank, the contemplated canal will, in all probability, be cut.

The site of this town was sold to $\mathrm{Mr}$. Berthoud, by Colonel Campbell, in 1808; shortly after, the land was surveyed by Mr. Woodrough, a plan drawn by Valcour, and the lots advertised for sale. A few cabins, however, were erected previously to this, in 1785, but owing to many local circumstances, no settlement, worth mentioning, was effected until the arrival of the Messrs. Tarascons; in 1806, to whom the greatest part of the town was conveyed, by 1 the said Mr. Berthoud. It is from this epoch that Shippingport may date its rise, for which 
it is not more inclebted to the great natural advantages of its situation, than to the public spirit and enterprising disposition of those gentlemen.

Shippingport is the natural harbor and landing place foi all vessels trading on the western waters with New Orleans, the Missouri, and upper Mississippi, the lower and upper Ohio, and in fine, in conjunction with Louisville and Portland, which, in some future day, will be all one great city, is the center port of the western country.

Nature has placed it at the head of the navigation of the the lower Ohio, as it has Louisville at the foot of the upper one, where all ascending boats must, during three-fourths of the year, of necessity, be compelled to stop, which they can do with perfect safety, as, immediately in front of it is a basin called Rock Harbor, that presents a good mooring ground, capable of containing any number of vessels, of any burthen, and completely sheltered from every wind. Rock Island, which forms the northern boundary of this basin, is a safe landing place, where boats frequently receive their cargo, which are carried 
over the Kentucky chute, this is only, however, when the water is low. The channel by Sandy Island (which offers a pleasant and commodious situation for repairing vessels) was obstructed by a nest of snags, which probably had existed there for centuries, and had been the cause of considerable loss of property, by sinking boats, which, from the swiftness of the current, it was lardly possible to steer clear of them. Last summer, however, Mr. L. A. Tarascon, at his own expence and with considerable difficuity, succeeded in raising and removing them. The wholc front of the town will be improved this summer. by the addition of wharves, which will facilitate the loading and unloading of steam boats that are coustantly arriving from below.

Shippingport originally consisted of forty-five acres, but it has since received considerable additions. The general outline of the town plot, as it now is, may be seen by a reference to the map. The lots are 75 feet by 14 feet, the arerage price of which at present is from forty to fifty dollars per foot, according to the advantages of its situation. The streets are all laid out at right angles; those that run parallel to 
the river, or nearly so, are named in succession, Front, which is sixty feet wide; Second, fifty; Thirl, fifty; Market, ninety; Tobacco, sixty; Bengal, thirty; Jackson, thirty; and Hemp street, which is sixty. 'These are all intersected by twelve feet allies, running parallel to them, and by cross streets at right angles; the first of which is called Mill street, sixty feet wide; the second, Tarascon street, the same width; then follow thirteen streets, which are named numerically.

The population of Shippingport, may be estimated at 600 souls, including strangers. Some taste is already perceptible in the construction of their houses, many of which are neatly built and ornamented with galleries, in which, of a Sunday, are displayed all the beauty of the place. It is, in fact, the "Bois de Bouloigne" of Luuisville, it being the resort of all classes, on high days and holidays.

At these times, it exhibits a spectacle at once novel and interesting. The number of steam. boats in the port, each bearing one or two flags, the throng of horses, carriages, and gigs, and the contented appearance of a crowd of pedes- 
trians, all arrayed in their "Sunday's best," produce an effect it would be impossible todescribe.

There were formerly here, as at Louisville, a number of rope walks, which are at present nearly all abandoned, there not being a sufficiency of hemp raised in the county to supply the manufacturers. This has arisen from the great losses sustained in the sales of cordage, which has discouraged the rope maker, and, consequently, offered no inducement to the farmer, to plant an article for which there was but little demand.

\section{NAPOLEON DISTILIERY.}

This is conducted by a gentleman from Europe, whose long experience and perfect knowledge of the business, enables him to fabricate the different kinds of distilled waters, cordials, liqueurs, \&c. which have been pronounced by connoisseurs, from Martinique and the Galleries de Bois, to want nothing but age to render them equal to any thing of the kind presented in either of those places.

MERCHANT MANUFACTURING MILL.

This valuable mill is remarkable, not only for its size and the quantity of flour it is calculated 
to manufacture when completed, but for the beauty of its machinery, which is said to be the most perfect specimen of the millwright's abilities to be found in this or any other country. The foundations were commenced in June, 1815 , and were ready to receive the enormous superstructure only in the spring of 1817. The building is divided into six stories, considerably higher than is usual, there being 102 feet from the first to the sixth. Waggons, containing the wheat or other grain for the mill, are driven under an arch, which commands the hopper of a scale, into which it is discharged and weighed, at the rate of seventy-five bushels in ten minutes; from this it is conveyed by elevators, to the sixth story, where, after passing through a screen, it is deposited in the garners; if manufacturing, from thence into a rubber of a new construction, whence it is conveyed into a large screen, and thence to the stones; when ground, it is reconveyed by elevators to the hopper boy, in the sixth story; whence, after being cooled, it descends to the bolting cloths, the bran being deposited in a gallery on the left, and the shorts in another to the right. The flow heing divid- 
ed into fine, superfine, and middlings, is precipitated into the packing chests, whence it is delivered to the barrels, which are filled with great rapidity by a packing press.

This noble and useful establishment is not yet finished, and has already cost its owner, $\mathrm{Mr}$. Tarascon, 150,000 dollars, and, when completed, it will manufacture 500 barrels of flour per day. Immediately above, is a line of mill seats, extending 2,662 feet, affording sites for works of that description, which, if erected, would be able jointly to produce 2,000 barrels in the twenty-four hours. Some experiments are now making by the owner, in order to deternine the . possibility of having a series of undershot wheels placed in the race above, to be propelled by the force of the current only. Should he succeed, he intends extending his works, and to employ this power for cotton spinning, fulling, wearing, \&c.

\section{PORTLAND.}

Portland is divided into Portland proper, and the enlargement of Portland. The former was laid out by Alexander Ralston, in 1814, by or- 
der of the proprietor, William Lytle, Esq. the latter was surveyed in $181 \%$, by Joel Wright, for the same gentleman. 'The lots in Portiand proper, are all half acre ones, while those of the enlargment are three-fourths of an acre. Those of the one when laid out sold for 200 dollars each, and havé increased from 500 to 1,000 dollars; those of the other sold for 300 dollars, and are at present worth from 500 to 600 dollars. But a small portion of this extensive place is as yet occupied by houses; some very hanulsome ones, however, are now erecting in Portland proper, and among them a very extensive brick warehouse, belonging to Capt. H. M. Shreves. 'The property in this place has lately attracted the attention of a number of wealthy men, who seem determined to improve to the utmost every advantage it possesses, and as it is not so subject to inundations as some of the adjoining places, its future destinies may be considered as those of a highly flourishing and important town.

\section{NEW ALBANY.}

New Albany is situated opposite, or rather below Portland, in the State of Indiana, and 
county of Floyd, of which it is the seat of justice. This town was laid out by the Messrs. Scribners, who were the proprietors, in 1814. It is built upon the second bank of the river, from which it presents a very interesting appearance, many of the houses being whitened, and one, belonging to Mr. Paxton, built of brick, and designed with considerable taste, meeting the eye in a most conspicuous situation. The bottom, * or first bank, is rarely overflowed, and the one on which the town stands, being twenty feet higher, there hardly exists the possibility of its ever meeting that fate.

For some time after it was laid out, New AIbany, like other places in the neighbourhood, increased but slowly, conflicting opinions and clashing interests retarding its growth. The many natural advantages it possesses, however, have at length surmounted every difficulty, and its progress of late has been unequalled by any town on the Ohio, of so modern a date. The good health generally enjoyed by the inhabitants, (which I think is partly owing to the excellent water made use of, which is found in na-

* This bottom is thickly covered with the Chenopodium Anthelminticum: 
tural springs, * to the number of fifteen or twenty, within the town plot, and which can any where be obtained at the depth of twenty-five feet,) the great road from this State to Vincennes, passing through it, and the quantity and quality of the ship timber which abounds in the neighbourhood, are the principal causes which have contributed to its advancement.

It contains at present one hundred and fifty dwelling houses, which are generally of wood, it being impossible to procure brick, in quantities suited to the demand. The number of inhabitants amount to 1000, and, from the influx of population occasioned by the demand for workmen at the ship yards, \&c. it must necessarily increase in a much greater ratio than heretofore. The only public works of any description, that are worth notice, is the steam grist and saw mill, belonging to Messrs. Paxton and Smith. Three steam boats have been launched from the yards, and there are three more on the stocks. The inhabitants are all

* At a little distance from the town, issuing from under a stratum of greenstone, is a spring of water containing a large quantity of sulphuretted hydrogen, which inflames on being brought into contact with a candle, and if the spring be covered with a close box, furnished with a pipe and stop cock, so as to condense the gas, it continues to burn until it is purposely extinguished. 
either methodists or presbyterians, the former having a meeting house, and the latter have contracted for a church, which is to be built immediately. There is a free school in this place, which has been partly supported by the interest of 5,000 dollars, a donation from the original proprictors, for that purpose, but increasing population requiring more extensive modes of education, other institutions are projected. Upon the whole, New Albany bids fair to. be a wealthy and important town, as it is becoming a depot, wherein the inhabitants of the interior of Indiana, draw their supplies of dry goods and groceries, and, consequently, to which they send their produce in return.

\section{CLARKSVILLE.}

Although this was one of the carliest settled places in the State of Indiana, being established in 1783, by the legislature of Virginia, as part of the Illinois grant, yet it is at the present moment far behind them all in every possible respect. A few $\log$ houses of one story, comprize the list of its diwellings, and from their number and appearance I should suppose that 
they do not contain altogether one hundred inhabitants. It is, however, pleasantly situated at the foot of the Indian chute, and immediately opposite Shippingport. It is said to be very unhealthy, which is more than probable from the number of marshes that are in the vicinity.

\section{JEFFERSONVILLE.}

Jeffersonville is seated on a high bank of the Ohio, nearly opposite Louisville, from which it affords a charming prospect, and immediately above the Falls. The town was laid out in 1802, and has increased considerably since that period, but it does not seem to progress, in the same ratio at present. It contains a market house, (which is never attended, the inhabitants procuring their beef, \&c. from Louisville,) a land office, court house, and a private bank, named the "Exchange Bank of" Indiana," J. Bigelow, president. About a mile from the town are several valuable springs, mineralized by sulphur and iron, where a large and commodious building has lately been erected, by the proprietor, for the reception of 
those who seek relief either from physical indis. position, their own thoughts, or the disagreeable atmosphere of cities, during the summer season; in a word, he is preparing it for a fashionable watering place, to which there is nothing objectionable but its proximity to Louisville; its being so near, requires neither equipage nor the expenses of a journey to arrive there, things absolutely required to render every place of the lind perfectly a la mode. It is, however, one of the most powerful natural chalybeate waters I have ever seen or tasted, and will, no doubt, prove very serviceable in many complaints, particularly in that debility attended with profusely cold sweats, which are constantly experienced by the convalescent victim of a bilious fever, so common to the inhabitants of this neighbourhood. Jeffersonville contains about 500 souls, and should a canal be cut there, in despite of the many natural obstacles that are opposed to it, its population must inevitably have a rapid increase. 


\title{
C A N A I. *
}

\author{
CHAP. VII.
}

WHEN we consider the rapidly increasing population, the rising importance, and the vast extent of fertile country above the Falls, a country containing from ninety to a hundred thousand square miles, the united lengths of whose navigable water courses may be estimated at five thousand miles, all of which lead to this dangerous pass; when we consider that this pass is the only one through which the inhabitants of that country can seek a market for their produce, and that the loss experienced by them in attempting to descend it, has been averaged at 20,000 dollars per annum! When, in addition to these circumstance, we consider the many public advantages and private gain to be derived from cutting a canal, we are astonished that it is not already completer.

* To acknowledge my obligations to the notes and surveys of Mr. Brooks, in this articles is, perhaps, superfluous, as it must appear, prima facie, that l have in several instances made free, not only with his ideas but with his language
also. 
That such a work is of great national importance, no one will pretend to deny, who, for a moment reflects upon the connexion and relative situation of the high and low countries, west of the Allegheny, with each other, and with those of the northern and eastern states.

Owing to a great variety of moral as well as physical causes, New Orleans and her surrounding territory always will be weak, and incapable, by themselves, of expelling an invader; their security, in time of war, will greatly depend upon the strong arm of the upper country, whose people are, and ever must be, agriculturalists, and who consequently never will permit a foreign power to conquer or loold possession of a spot, that would cnable it to command the passage to their great natural outlet, the Gulf of Mexico, whose undisturbed possession is of the utmost importance to their prosperity, and to secure which the latter must place the trident of the Union in the hands of their eastern brethren and maintain it there! Thus mutual dependence will secure a bond of union between them all.

Celerity in military affairs is universally ac- 
knowledged to be a great and important point, and the delay of a single day, sometimes of but a few hours, is often productive of the most disastrous consequences. The difficulty and danger, and, during a considerable portion of the ycar, the absolute impracticability of conveying over the rapids, troops from above, miglit, in case of war, occasion a loss of time fatal to the successful operations of a whole campaign, and be the mears of delivering to the sword of the enemy, one of our most valuable possessions, an event which could never happen, were the obstacle ${ }_{s}$ which might retard the arrival of forces sent to its relief, removed by a canal.

Another great advantage arising to the public from such an undertaking, would be the convenient and spacious site it would afford for a great military depot, a foundry and armoury.

From hence, arms, provisions, and all other necessary and indispensable munitions of war, can be conveyed with ease, safety, and despatch, by means of steam boats, to almost any given point; and it certainly is a desideratum for those. who by their situation are destined to become the repellers of foreign aggressions, to 
have among themselves, sources whence, at any moment, they may be supplied with weapons essential thereto.

These benefits, though great, are not the only ones the public would receive from the work in question, during the troublesome times alluded to; for, until our navy is sufficiently powerful to sweep the ocean, and claim its entire dominion, all the cotton, sugar, and other valuable products of the lower country, must necessarily ascend the Ohio to Pittsburg, in order to reach in safety the castern manufacturer or consumer. How much a canal would facilitate such transportation, and what a reduction of the expenses attendant on the same it would occasion, I leave for the calculation of such as have already experienced the weight of the argument.

An idea, futile in its nature, and injurious in its tendency, has been started by a few individuals, whose self-interested motives can hardly be admitted as a sufficient excuse, for thus damping the flame, and opposing the progress of public improvement. If you cut a canal, (say they to the inhabitants of this place, ) that mo. 
ment the great commercial advantages you have hitherto experienced, for ever leave you, and your boasted town sinks upon a level with every other city on the Ohio!

Do these gentlemen really believe that Louisville draws her importance solely from the obstruction to the navigation of the river, or do they pretend to assert, as the result of experience, that a canal, (no matter where,) has ever: deducted from the population, wealth, or business of a town, through which it has passed? I imagine not. It never has, it never can, unless, indeed, it happen to be one connecting a miserable asscmblage of roofless huts, with a city of palaces, when, indeed, there would be but little inducement to make the former a stopping place, which Louisville must always continue to bc, canal or not, until some equally large town affording all the luxuries and conveniences of life found within her precincts, be built immediately in her vicinity, and principally until the depth of water in the river above the Falls, in low stages of water, be rendered equal to that below it.* In estimating the many natural ad-

* Let not this observation be considered by the opposers of a canal, as a tacit conviction in my own mind, of the uselessuess of such an undertaking; for, 
vantages which Louisville possesses, over her sister cities, they seem to have forgotten the immense and fertile country, of which she is the debouche, and not to have reflected upon the locality of her site, in relation to the country watered by the Ohio and its branches, which, with due attention to improvement, may be made to remedy the deficiency of water power, a deficiency so gencrally acknowledged and universally deplored throughout the whole of its valley.

Are they aware, I would ask them, of the number of manufactories that a canal would justantly create, and of the immense capital necessarily expended in the completion of it, and the erection of such works, all of which would consequently centre here? or, do they deem an influx of labouring population, and the money acquired by it, (which nust ultimately find its way into the pocket of the citizens, ) nothing?

although it be a fact, no inference can be drawn from it unfarorable to such a work, as they will please to recoliect, that while there is often a sufficiency of water to float a steam boat drawing six feet, from Pittsburg to the Falls, there is not near enough on them to permit her to pass over. The only correct idea that it suggests, is the propriety of having a nunber of boats smaller than those generally in use at this time, ilat would draw but from fifteen to twenty inches water wisen loaded, which might reeeire and divide anong them the lading of the large vessels (which must always be eompelled to stop at Shippingport) and thus be able at all scasons and stages of the water, to ply between littsburg and Louisville. 
It is, in fact, owing to a circumscribed, inpolitic, and jealous view of the subject, that any objections to it ever have becn raised. The loss of the profits accruing from the portage round the Falls, would be amply compensated for by the additional spring given to commerce, by the perfect safety with which boats of every description could pass this at present formidable and intimidating spot, whose terrors have, paralized the arm of enterprize, by the increased population which the canal and manufactories erected thereon would incvitably attract; and, finally, by the dormant wealth of an infinitely extensive country, which it would bring into circulation.

As a proof of the importance attached to it by the general govermment, a bill was passed in 1809 or 1310, authorising the subscription of 150,000 dollars, to the capital stock of the Ohio Canal Company. But had that bill passed into. a law, it would have been productive of no good, until the work was commenced by the company. itself, which, previously to receiving any aid from the executive, was (by a clause of the said bill.) obliged to have a sum funded equal to one Aa 
half of the amount required, to have made other arrangements relative to cutting the canal, and to have reported the same, with every necessary explanation, to the President of the United States.

Agrecably to a resolution of the assembly of Kentucky, dated the 20th of December, 1815, the co-operation of several states was requested, for the prosecution of that design in whose success they were all so deeply interested, but so large a slice of the cake had been reserved by the assembly lor herself, as left little or no inducement for the others to accept of the invitation. "The number of shares subscribed for on the part of Kentucky amounted to 1000 , $(50,000$ dollars, $)$ and a thousand more were reserved for her future disposal, the Governor for the time being having a right to vote according to such shares!! No part of the said subscription was to be paid for until 3,000 shares riere taken elsewhere, and then each payment on the part of Kentucky not to exceed 10,000 dollars per annum, unless by the consent of the assembly!!

No sooner had the Legislature of this State 
passed an Act incorporating the Ohio .Canal Company, for the purpose of cutting a canal on the south side of the river, than considerable competition arose, and the pre-cmincnce of the north side was most loudly proclaimed by several individuals, who at length succeeded in procuring an act of incorporation, under the name of the Indiana Canal Company, but not in obtaining from congress a favorable answer to their modest request for ' a pre-emption of land ' enabling them to divide their' rights into seve'ral parts, and that before all the best lands 'were sold, with the remittance of part either 'principal or interest, and on longer than usual 'credit.'

About this time there appeared a pamphlet, which, to use the words of another, "sufficiently exposed the scheme out of which it grew, and the lameness of the projcctor." As there is nothing in it, with the exception of a few sentences, that would repay the trouble of transcribing, we must, thereforc, after noticing those, consign it to its usual and, I lopc, hereafter, eternal slumbers.

In a letter from General B. Hovey to the 
company, (proposed, not yet incorporated) of Indiana, dated the 28th of July, 1805, we have,

"When I first viewed the rapids of the Ohio, it was my object to have opened a canal on the side of Louisville, but, on examination, I discovered such advantages on the opposite side, that I at once decided in favour of it." In document No 4; accompanying the said letter, we read, "the west bank of the Ohio is more favorable to the opening of a canal, to avoid the rapids than the east bank." And again, "the approximation of two deep ravines, the one discharging into the Ohio, above the rapids, and the other below the steepest fall, will aid the operation powerfully, and save great labor and expense,." Also, "the distance on the west bank, will be shortened one-third."! Credat Judous!

It secms really unfortunate for the General, that he does not declare what those advantages are of which he speaks so vauntingly, as it must have puzzled any other man besides himself and coadjutors, to have discovered them, and it is equally a pity, that the author of No. 4, was not accompanied in his scientific and laborious investigation, hy some instrument that might. 
have enabled him to hare corrected a trifling crror into which he has falien-that of mistaking the northern and southern points of the compass for the eastern and western ones.

Where the ravines he speaks of which are to occasion such an economy of time, labor, and expense, are to be found, I am really at a loss to imagine. One of the engineers employed here, conjectures he must mean Mill Creck, and a short ravine above Jeffersonville. If sos their approximation is possitively denied, both by that gentleman and myself, * their heads cannot be brought to any given point, without cutting for nearly a mile through high a land of ridges and marshes.

The upper ravine is only seven hundred and twenty yards long, and is not entitled to that name for more than half that length, the looseness of the earth near its commencement having suffered it to wash deep.

Mill Creek, after leaving an extensive, high, and swanpy wilderness, meanders through a broken country, in a circuitious route, and falls into

* Every inch of the ground spolsen of above, has been repeatedly traversed by me, in my botanical excursions, and 1 can safcly add my mite of testimony to the more weighty opirion of Mr. Brools. 
the Ohio at the foot of the rapids; some dis. tance from its mouth, the bank is about fifty feet high, but near it, the ground is low; immediately opposite, are large sand bars, which vary their figures with every descending frest, one collection of this kind fills the whole of the bend in the shore below.

A canal on the north side, to be of any service at all, must commence as high as the ravine above Jeffersonville, in order to avoid the suction or dangerous draught of the Indian chute, and, if it be intended to avoid the Falls, can only enter the Ohio above Mill Creek, a distance, taking every possible advantage of the ground, that is not less than three miles and a half.

Several different routes for a canal on the Indiana side have been proposed at different times, all of which evince the sagacity of the proposers. One of them would lead (after cutting through a bank sixty feet high) into a basin, past which the current runs thirteen miles and a half per loour, in time of slack water, and directly below which is the most dangerous cataract, of the whole Falls!! Another would, 
it is true, escape that danger, but would not avoid the rapids by half a mile. A part of this basin is an eddy, at a certain elevation of the water, past which the current exceeds nine miles and a half per hour, which throws every thing against the rock-bound shore of the east end of Clarksville, except in low water, when a reef, projecting from beneath them, obstructs the passage of a very narrow channel, north of and close to Rock Island. I leave it to those, (says Mr. Brooks,) whom it may amuse, to consider the difficulty of ascending past that range of battered cliffs, and gaining the foot of a canal in that basin, and whether it is possible for a boat to be taken from it and escape those cliffs, the cument allowing less than two minutes of time for that purpose. In addition to this, all boats ascending the river must cross from the Shippingport channel, which will at all times be irksome, and, at certain stages of the water, utterly impossible.

From far above the ravine near Jeffersonville, to opposite the bend in front of that town, there is one high and steep bank of loose ground. From a little below this, the projecting bank 
of the cast end of Clarksville is supported by a high shelving rock, three hundred yards in length, by which the whole force of the rapids is rebutted. Should the rock continue through the ground of the contemplated canal, at the height it appears from the bank, the bulk to be cxcavated would be an appalling circumstance?

Rock is essentially necessary at the head and foot of a canal, so that if not naturally there it must be placed there; none appears near the month of Mill Creck, nor near the upper ravine, but a loose gravel commences within a few feet of the surface, and coutinues to the depth of forty feet, which must necessarily be the average depth of a canal from that place, althongh some of the ground is low.

A great portion of this bank being broken by many ravines which wind among the high ridges, render the face of the country very rough and uneven. A canal must necessarily intersect those ravines, and the difficulty of dispers. ing the water collected by them, from so wide a country as they possess, is a matter that requires serious consideration before it is commenced. From these sources the works would 
be assailed by tremendous torrents, not only in wet seasons, but with every shower of rain that fell bringing down with them all the rubbish collected from the wilderness through which they run.

The difficulty of forming, keeping open, and in order, a suitable harbor at the head of the canal, in the bold and sandy shore above Jeffersonville, would be very great. During a portion of the winter, if any ice be in the river, a considerable quantity of it adheres to the shore, rendering it impossible for boats to approach it. This being the case, and the boat not being able to enter the narrow passage designed for her, (allowing it to be possible to keep one open), she would necessarily get within the draught of the Indian chute, and, (unless precipitated over the Falls,) make the harbor of Bear Grass, and such as do make this harbor, by not venturing too near the Indiana shore, at this dangerous place, cannot afterwards be benefitted by a canal on the north side.

In fact, so many powerful obstacles to the formation of a canal on the north side, present themselves to the mind, in such rapid succes$\mathrm{B} \mathrm{b}$ 
sion, that they appear insurmountable, and batfle every attempt that can be made relative to the expense of such an undertaking, and the time necessary to complete it. To the southern or Kentucky shore, therefore, all competition must inevitibly yield, however mighty may be the struggle. In order to pour a noon-tide blaze of evidence upon this assertion, and to silence for ever (if possible) the clamours of a few interested persons, let us for a moment cast our eyes on the south bank, and mark the difference, in every respect, favorable to the latter.

By recurring to the map, we observe that the Ohio suddenly winds to the S. W. forming an elbow, in which lies Shippingport, leaving between it and the second bank, on which Louisvilie is built, a fertile and beautiful bottom, throngs which the contemplated canal is to ritiv ose length as laid down upon the map, accong to the survey of Messrs. Baldwin and Bros, is only 583 poles. ' It, however, is asserted, that to avoid any possible danger from the swiftness of the current, it ought to run in the track of the dotted line which would carry it completely below the Falls, and still be only 
700 poles in length! whereas, as was before observed, that of Indiana must needs be three miles and a half or, 1120 poles!!

The difference, however, of the length is by far the least important consideration, in favor 'of a canal on the Kentucky side, the different formation and nature of the ground, which seems absolutely designed by nature to facilitate the operation, is what principally strikes the attention of every unprejudiced man. About sixteen feet from the surface, (along the different tracks of the canal) a stratum of flat rock composed of limestone and schistus, is constantly found, forming a beautiful and durable floor, that part of it requiring to be excavated furnishing ample materials for walling and the perfection of the locks, and between it and the surface, nothing intervenes but a tenacious yellow and blue clay, mixed with a very small quantity of sand. No ravines disfigure the surface of this beautiful bottom, oppose the least obstacle to the progress of the workmen, or menace future destruction to the canal when finished; nothing is wanting here to complete that work which Providence seems to have begun, but simple labor: 
One of the reports which have been so indus. triously circulated by those who, for purticular reasons, were inimical to a canal, is, that the ground in this situation is too low. Allowing this to be the case, (which it most decidedly. is not,) plenty of higher ground may be obtained on each side of it, and, if wanted, as high as fifty feet.

IMr. Baldwin, who was employed by the Ohio company, says, "Certain it is, that my apprehensions of the difficulties and dangers of the work have been nearly all removed by $\mathrm{Mr}$. Brooks, who has well considered them hirnself, who has long (seven or eight years) watched the effect and judiciously investigated the forces of those incontrovertible floods.* He is well acquainted with the facts and the science, by which an estimate of the feasibility of the work in question can be made, and as I have not been able to view the river, in all its unusual changes, I am convinced with him, that the work is practicable."

This is high and honorable testimony, and only brought forvard to prove that such a man could 
not, after calmly and for years investigating the advantages and disadvantages, presented by the two sides of the river, with respect to cutting a canal, decide so positively on the southern one, as being its only proper site, without having the strongest reasons for so doing. Previously to applying instruments, (says he,) to asccrtain precisely the situation of the ground, I traversed and examined it thoroughly, on both sides of the Ohio, and used every endeavour to discover some foundation for the reports in favor of the northern one, but the great length, and forbidding aspect of the country, through which a canal should necessarily be carried, and the danger and-difficulty of approach to places where the head and foot of a canal should be, fully convinced me of the utter impracticability of effecting it, until many years had elapsed, and brought into existence far more and greater cncouragement for public and private enterprisc, admitting there to be no other practicable route, for a canal.

As the dotted track has never yet been properly examined, we will suppose that the canal is to rin in the manncr laid down on the map, 
always bearing in mind, that increasing its Yength, breadth, or depth will constitute a certain additional number of cubic yards of earth and rock to be removed, the expense of which may be easily calculated from the data on which the following estimate is founded, and which, to give the real expence of the work, must be added to it.

Before, however, entering upon this estimate, it is necessary to observe, (a remark respectfully submitted to the consideration of the executive, that the pcople of this country have been so often disappointed in their expectations relative to the subject spoken of, that their confidence in any plan that may be proposed, cannot be obtained unless they see it emanating from the General Government of the United States: whose aid and countenance in this undertaking every inhabitant of this section of the Union sincerely prays for. The sites for a spacious foundry and armoury are offered to them, and the ground through which the canal is to pass, has, by its liberal owner, been transferred in perpetuity to the company.

By thus placing a portion of the public trea- 
sure where it would most contribute to the pubs lic good, Congress has it in her power to erect a monument to herself, and thereby to secure the only just reward of an honest legislature's ambition, a people's thanks; and that I may not be suspected of unworthy motives, in the sketch I have just given of the business, I deem it essentially necessary to declare, that I am neither a speculator nor stock jobber, and that I have not, directly or indirectly, a single foot of landed property in the western country, or am in any way to be benefited, so far as respccts my private concerns, by the cutting of a canal. Had things been reversed, and had the same facility of performing the work

Note.-Since the above was prepared for press, a fresh and vigorous attempt has beeu made, to have the work performed on the north bank of the Ohio, to which the legislature of Indiana has extended a belping hand, by authorising, in favor of it, one of those legal gaming schemes called a lottery.

To demonstrate the impropriety and injurious tendency of similar acts of government, whose attention should be directed to repress, rather than inflame, that direful passion for the doctrine of chances, which is already too strong in every country, and which in the end, induces nothing but misery and despair, in those who unfortunately become its slaves, is a matter foreign to my subject; but, thoroughly convinced of the impossibility of effecting this great and necessary public work on that side of the river, without an enormous expenditure of time and treasure, I would seriously request those who intend embarking in the cause, not by the purchase of lottery tickets, but by that of stock, to pause one moment, and, 'ere it be too late, cooly to reflect on what may be the result.

Let them walk over the ground through which it is to be carried, let them consider its nature, ${ }^{*}$ the necessary length and depth of the canal, the unavoidable quantity of solid rock that must be removed; let them take their pens and calculate how many cubic yards of that stubborn material and of earth must be taken

- If non-residents, let them depend upon the report of any dişinterèsted man. 


\section{SKETCHES OF LOUISVILLE.}

on the south side, existed only on the northem one, and had the many difficulties which actually there present themselves, been transferred to the south side, I should have declared most unequivocally for the former.-- 6 Truth is neither Guelph nor Ghibelline."

away from a space three miles and a half long, thirty feet wide, and, at least, forty teet deep; let them consider the expence of locks, \&e. necessary to complete it, and when they have done all this, if they find that there exists a shadow of possibility that the sum total can ever be procured, lct them enquire what dividend can ever result from the profits of an undertaking so expensive.

Sercral professed engineer's have repeatedly examined both sides of the river, and as repeatedly pointed out the facility with which it may be performed on the south bank for 300,000 dollars, when as to the cost of the other they would not hazard a con jecture. In all probability, however, little less than *s******** dollars would be requisite to do the business properly, and it is the opinion at this moment of the most intelligent men, that however soon it may be commenced, time will never see it finished. 


\title{
NAVIGATION AND COMMERCE.
}

\author{
CHAP. VIII.
}

THE increase of the navigation and commerce of Louisville and Shippingport, since the year 1806, is, perhaps, unparalleled in the history of nations. At that time, six keel boats and two barges, the one of thirty tons, belonging to Reed, of Cincinnati, the other of forty, owned by Instone, of Frankfort, sufficed for the carrying trade of the two places, whereas at the present moment, there are (exclusive of barges, lieels, \&c.) upwards of twenty-five steam boats employed in that business, whose united burthen is equal to six thousand and fifty tons !'This is a flattering and unequivocal proof of their prosperity, and gives us a glimpse of what they will be fifty years hence.

The application of steam to the purposes of navigation, constitutes a brilliant and important era in the annals of our country, and although Fulton was not the original inventor, $\mathrm{C}$ c 
(for it had been repeatedly essayed before his time, in England, France, and this country, but without success) yet is his merit not the less on that account, as it requires more courage to persevere in effecting a purpose, which, from the constant failure of others, seems to be inpracticabie, than to try a new experiment."Why has he not a statue?"

Next to Fulton, the westem country owes a vast debt of gratitude to Capt. H. M. Shreves, of Portland. It is to his exertions, his example, and, let me add, to his integrity and patriotic purity of principle, that it is indebted for the present lourishing state of its navigation. Having been long convinced that the overpowering patent of Fulton and Livingston, which granted them the exclusive privilege of narigating by steam boats, all the rivers of the United States, for fourteen years, no matter in what manner the steam operated, was illegal, and consequenty of no effect, he determined to bring the point to issue, and accordingly, on the 1 st of December, 1814, he embarked in the ENTenprize, for New Orleans, where he arrired on the 14th of same month. Immediatcly on landing, he applied to counsel. 
and procured bail, in case of seizure, which took place the ensuing day. Bail. was entered, and a suit commenced against the ressel and owners, by the company, in an inferior court, where a verdict was found for the delendants. 'The cause was now removed by a writ of crror, to the supreme court of the United States, at which time the Enterprize left New Orleans and arrived at Shippingport.

Before the question was decided by this tribunal, Capt. Shreves returned to New Orleans with the Washington, a beautiful boat of 400 tons, which, (as expected,) was also seized by the company, to whom she was abandoned without any difficulty. Upon application, however, to the court, an order was obtained to hold it (the company) to bail, to answer the damages that might be sustained by the detention of the ressel; to this it demurred, and, beginning to feel the weakness of its case, and foresecing the downfall of its Colossal patent, it repeatedly offered (both througl the medium of its attornies and by its members, personally) to admit Captain Shreves to an equal share with itself, in all the privileges of the patent right. mrovided he 
would instruct his counsel so to arrange the business, that a verdict might be found against him!!! In vain this tempting bait (I had almost said bribe) was proffered. It was rejccted with scorn and indignation, and the affair left to Justice, whose sword, at one blow, forever severed the links of that chain which had enthralled the commerce of the western waters. Had Captain Shreves been weak enough to have accepted of this offer, the result is obvious. No one would have dared to embark his fortunes in vain equdearours to promote the best interests of his country, by adding the wings of commerce to the feet of agriculture, because ruin wouid have been the inevitable consequence; the carrying business would have remained in the hands of the company, who would have continued just as many and no more boats in the trade, than was sufficient to keep up the price of freight, and, consequently, instead of paying two and a half cents per lb. for every article of import, the merchant, and ultimately the consumer, (for upon his shoulders such things always bcar at last) would have becn compelled to have paid six, seven, or eight, as 
best suited the interest or convenience of the company.

Among the many decided advantages which steam boats possess, over those of any other description, the most obvious are, the safety with which they carry their freight, and the short space of time in which their passages are performed, thereby enabling the freighter to turn his money to advantage frequently in the course of the year, as well as to avoid the heavy losses so often occasioned by perishable commodities in long voyages. It also enables him to sell his goods cheaper, as they cost him less than in any other way, and here the consumer, and consequently the whole country are the gainers.

Another sensible advantage arising from them is the extraordinary demand they occasion for fuel and provisions. With respect to the former, that wood which hitherto cost the owners of land considerable sums to destroy, will now bring from two and a half to ithree dollars per cord, delivered any where on the banks of the river! As to the latter, the country in the immediate vicinity of Louisville can scarcely cqual the rlemand created by them and the in- 
creasing populalion of the town. This may serve as explanatory of the note to the artic!c Soil. When there happens to be six or seven steam boats in port at once, it is extremely difficult to procure the most common productions of the farm, and it is not uncommon to see péople riding out on horseback to intercept the provisions destined for the market. The hotels, taverins, and steam boats must be supplied, cost what it will, and so great is the quantity required for that purpose, that the citizens of the town are very frequently at a loss for provisions for their table, if we except the articles of beef, mutton, and potatoes.

* Each of the steam boats cmployed in the trade of this place is obliged to disburse 600 clollars per trip, at least threc times in the year, or 1,800 dollars, which multiplied by the number of boats gives us 45,000 dollars, a sum annually expended among the owners of land at this place and along the river below. 'The effect of this will quichly be perceived in the improvement and settlement of the country. But these are not the only advantages derived to the western country, by the introduction of 
steam boats; their re-action has been productive of good turnpike roads over the mountains, of good canals, Sc. thus diminishing the price of freight from the castern states, whose inhabitants, fearing the entire loss of the trade with the western country, have been stimulated to comteract their effects by means just mentioned.

From what has been said, it follows that the stcam boat navigation occasions an improvement of the country, and the improved state of the country demands an increase of steam boats. It would appear at present that the increase will soon cxceed the demand, but that is a circumstance beneficial to the public, although it may cause a partial loss to the boat owners. The first effect produced will be a scarcity of freight and a consequent reduction of the rates. This reduction benefits the importer and the consumer. It will also cause many bulky articles to be brought up the river which could not: be done at the present prices. It will compel boat owners to use more cconomy in fuel and wages, thereby creating a demand for better boats and more perfect engines, capable of 


\section{working at less expense. 'The increased ex- perience of the workmen will be enabled to fur- nish these, the price of freight once lowered would remain so, and steam navigation yield the same profit it did at first, when less skill was applied and it required more capital.}

\section{$\longrightarrow+$ \\ STEAM BOATS \\ EMPLOYED ON THE WESTERN WATERS,}

From 1812 to 1819.

1st. The ORLEANS, the first boat built at Pittsburgh, owned and constructed by Mr. Fulton. Sailed from Pittsburgh in December, 1812, and arrived at New Orleans about the 24th of the same month, and run betwecn New Orleans and Natchez about two years, making her voyages to averagc serenteen days. Was wrecked near Baton Rouge, where she sunk on the upward bound passage

2. The COMET, owned by Samuel Smith, built at Pittsburgl, by Danl. French, stern wheel and vibrating cylinder, on French's patent, granted in 1509. The Comet made a voyage to Louisville in the summer of 1813, and descended to New Orleans in the spring of 1814 ; made two royages to Natchez, and was sold-the engine put up in a cotton gin. - - -

3. The VESUVIUS, built at Pittsbargh, by Fulton, and owned by a company of gentlemen belonging to New York and New Orleans. Sailed for New Orleans in the spring of 1814, commanded by Captain Frank Ogden ; sailed from New Orleans for Louisville, about the 1st of June following; grounded on a sand bar 700 niles up the Mississippi, where she Iay until the $3 \mathrm{~d}$ of December, when the rirer rose and floated ber off. She was then employed some montlus between New Orleans and Natchez, under the command of Captain Clemmont, who was succeeded by Captan John DeHart; shortly after she took fire, near the city of New Orleans, and burned to the water's edge, having a valuable cargo on board. The fire ras supposed to have been communicated from the boiler, in the Lold ; her 
bottom was afterwards raised and bnilt upon at New Orleans. She has since been in the Louisville trade and has lately been sold to a company at

Natchez

4th. The ENTERPRIZE, built at Brownsville, Pa. on the Monongahela, by Daniel French, on his patent, and owned by a company at that place. She made two voyages to Louisville in the summer of 1814, under the command of Captain I. Gregg. On the 1st of December she took in a cargo of ordnance stores at Pittsburgh, and sailed for New Orleans, commanded by Captain H. M. Shreve, and arrived at New Orleans on the 14th of the same month, and was then dispatched up the river in pursuit of two keel boats, laden with small arms, which had been delayed on the river. Twclre miles above Natchez she met the keels, took their masters and cargoes on board, and returned to New Orleans, having been but six and a half days absent, in which time she run 624 miles. For some time after, she was actively employed in transporting troops, \&c. She made one voyage to the Gulph of Mexico, as a cartel ; one voyage to the rapids of Red River, with troops ; nine voyages to Natchez; set out for Pittsburgh on the 6th of May, and arrived at Shippingport on the 30 th, (25 days out), being the first steam boat that ever arrived at that port from New Orleans. From thence she proceeded on to Pittsburgh, and the command was given to capt. D. Worley, who lost her about 12 months after, in Rock harbour, at Shippingport.

5th. The RETNA, built at Pitsburgh, and owned by the same company as the Vesuvius-sailed from Pittsburgh, for New Orleans, in March, 1815, under the command of captain A. Gale, and arrived in April followingcontinued in the Natchez trade. Was then commanded by captain $\mathbf{R}$. D'Hart, who made six voyages in her to Louisville, and is now commanded by captain $\mathbf{A}$. Gale, in the same trade.

6th. The DISPATCH, built at Brownsville, on French's patent, and owned by the same company as the Enterprize-she made several voyages from Pittsburgh to Louisville, and one from New Orleans to Shippingport, where she now lies a wreck, her engine out-was commanded by captain

\section{Gregg. - - - - - - - - - - - - -}

7 th and Sth. The BUFFALO 300 tons, and JAMES MONROE, 90 tons, built at Pittsburgh, by Latrobe, for a company at New York, but failed in finishing them. They were sold at sheriff's sale, and fell into the hands of Mr. Whiting, and finished by h.m with engines-both dull sailers.

9th. The IVASHINGTON, a two-decker, built at Wheeling, Va. constructed and partly owned by captain Henry M. Shreve ; her engine was made at Brownsville, under the immediate direction of captain Shrere. IIer boilers are on the upper deck, being the first boat on fluat plan, and is 


\section{Erought over}

a valuable improvement by captain Shreve, which is now generally in use. The Washington crossed the Falls in September, 1316, commanded by captain Shreve, went to New Orleans, and returned to Louisville in the winter. In the month of March, 1817, she left Shippingport a second time, proceeded to Ncw Orleans, and returned to Shippingport, being absent but 45 days. This was the trip tliat convinced the despairing public that steam boat navigation would succed on the western waters-she has since been running with similar success in the same trade. - _ _ _ _ - - 400

10th. The FRANKLIN, built at Pittsburgh, by Messrs. Shiras \& Cromwell ; engine built by George Erans-sailed from Pittsburgh in December, 1816 ; was sold at New Orleans, and has been in the Lovisville and St Louis trade since that time--she was. sunk in the Mississippi, near St. Genevieve a few months since, under the command of eaptain Recd, on her way to St. Louis.

11th. The OLIVER EVANS, (now the Constitution) 75 tons, was built at Pittsbuxgh, by Mr. George Evans-engine lis patent-she lcft Pitisburgh in December, 1816, for New Orleans; in April, 1817, she burst one. of her boilers, off Coupee, by which eleven men lost their lives, principally passengers.-Has done but little since.-Is now owned by Mr. George Sutton and others, of Pittsburgh. -

12th. The HARRIET, built at Pittsurgh; owned and constructed by Mr. Armstrong of Williamsport, Pa.-she sailed from Pittsburgh, October, 1816, for New Orleans, and crossed the Falls in Mareh, 1917 ; made one voyage to New Orleans, and has since been run betwcen that place and the Muscle Shoals.

13th. The PIKE, a small boat built by Mr. Prentiss, of Henderson, $\mathrm{Ky}$. run some time from Louisville to St. Louis, from thence in the lied Fiver Trade. Was lost on a sawycr, March, 1818.

14th. The KENTUCKY, built at Franlifort, Ky. and owned by Hanson and Boswell-in the Louisville trade - _ _ _ _ _ _ _

15th. The GOV. SHELEY, built at Louisville, Ky. by Messrs. Gray, Gwathmey, and Gretsinger-Bolton and Watts' engine.-Now pcrforming very successfully in the Lotisville tracle. - $\quad$ - $\quad$ - $\quad$ - $\quad$ - 120

16th. The NEW ORLEANS, built at Pittsburgh, in 1817, by Fulton and Livingston-in the Natchez trade. Near Baton Rouge, she was sunk and raised again, and sunk at New Orleans, in Fcb. 1S19, abont tivn montis after her sinking near Baton Rouge. - - - - _ - - 300

17th. The GEORGE MADISON, built at Pittsburgh, in IS1S, oy Messis. Voorhies, Mitchell, Rodgers, and Todd, of Frankfort, Ky.--in the Louisville trade. 
Brought on - - 3075

1Sth. The OHIO, built at New Albany, In. in 1818, by Messrs. Shreve and Blair -in the Louisville trade. - - _ _ _ - - 443

19th. The NAPOLEON, built at Shippingport, in 1813, by Messrs. Shreve, Miller, and Breckenridge, of Louisville-in the Louisville trade. - 332 20th. The VolCANo, built at New Albany, by Messrs. John and Robeson De Hart, in 1818-in the Louisville trade. - - - - $\quad-250$

21st The GEN. JACKSON, built at Pittsburgh, in 1818, and owned by Messis. R. Whiting, of Pittsburgh, and General Carroll, of 'Tennessee-in'

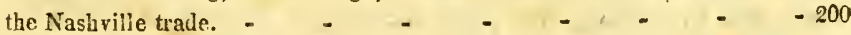

22d. The EAGLE, built at Cincinnati, in 1818, owned by Messrs. Jas. Berthou and Son, of Shippingport, Ky. - in the Louisville trade - -

93. The HECLA, built at Cincinnati, in 1818, and owned by Messrs. Honore and Barbaroux, of Louisville - in the Louisville trade. - -

24th. The HENDERSON, built at Cincinnati, in 1818, and owned by MIessrs. Bowens, of Ienderson, Fy. - in the Henderson and Louisville trade. - - - - - - - - - - - -

25. The JoIns 0 , built at Whecling, in 1818, by George White, and oivned by Messrs. J. \& R. Johnson, of Kentucky-in the Louisville trade 26th. The CINCINNATI, built at Cincinnati, in 1818, and owned by Nessrs. Penniwit and Burns, of Cincinnati, and Messrs. Paxson and Co. New Albany-in the Louisville trade.

27th. The EXCHANGE, built at Louisville, in 181s, and owned by Davit L. Ward, of Jefferson county, Ky. - in the Louisville trade $\quad-\quad-200$

25th. The LOUISIANA, built at New Orlcans, in 1815, and owned by Mr. Duplissa, of New Orleans-in the Natchez trade. - - _ 45

29th. The JAMES ROSS, built at Pittsburgh in 181s, and owned by Messrs. Whiting and Stachpole, of Pittsburgh, -in the Louisville trade. This boat has lately made a trip from New Orleans to Shippingport, in sixtecn days and a half, haring lost sixty-one hours and eight minutes discharging cargo on the way. Had on board 200 tons cargo.

30th. The FliANKFORT, built at Pittsburgh, in 1818, and owhed by Messis. Voorhies and Mitchell, of Frankfort, Ky.-in the Louisville trade. 320 31st. The TAMERLANE, built at Pittsburgh, in 1818, and owned by Messis. Boggs and Co. of New York-in the Louisvillc trade. - - $\quad 320$ 32d. The CEDAR BRANCH, built in 1818, and owned at Maysville, Ky. in the Lonisville trade.

33d. The EXPERIMENT, built at Cincinnati, in 1818, and owned at that place.

34th. The ST. LOUIS, built at Shppingport, in 1818, and owned by Messrs. Hewes, Douglass, Jolnnston, and others-in the St. Louis trade. - 220 
TONS.

Brought over - -6460

35th. The VESTA, built at Cincinnati, in 1817, and owned by captain 3 cnkins of that place-in the Louisville trade.

36th. The RIFLEMAN, built at Louisville, in 1819, and owned by

Messrs. Butler and Barners, of Russelville, $\mathrm{Ky}$.-in the Louisville trade 250

37th. The ALABAMA, a small boat, built on Lake Ponchartrain, in 1818-in the Red River trade.

38th. The RISING STATES, built at Pittsburgh, in 1819, and owned by Wm. F. Peterson and Co. of Louisville-in the Louisville trade. - -

39th. The GENERAL PIKE, built at Cincinnati, in 1819, intended to ply between Louisville, Cincinnati, and Maysville, as a packet, and owned by a company in Cincinnati.

40th. The INDEPENDENCE, altered from a barge, owned by captain Nelson, and intended to ply between Louisville and St. Louis.

41st. The UNITED STATES, built at Jeffersonville, In. in 1819, owned by Hart and others, and has two separate engines, made in England. She is doubtless the finest merchant steam boat in the universe, drawing but little water, and capable of carrying 3,000 bales of cotton-in the Louisville trade." =

\section{BOATS NOW BUILDING.}

Two at Pittsburgh, by R. Whiting, 180 each, One ditto, by Stackpole and Rogers, - Two at Wheeling of 500 and 100, - One at Stubenville One at Marietta, One at Maysville,

One at Cincinnati, by Noble and Moore, One ditto, by Breedlore and Bradford, Two ditto, for a company at Nashville, 250 each; One at Portland, Ky. by Gray and Anderson Three at New Albany, by Shreve and others, each 220, Four at Clarksville, In. from 60 to 200 One at Salt Rivcr. by a company at Elizabethtown, $\mathbf{K y}$. One at Vevay, One at Madison, One at Rising Sun, One on the Wabash River Two at New Orleans, 200 each, $\begin{array}{ll}- & - \\ - & - \\ - & - \\ - & - \\ - & - \\ - & - \\ - & - \\ - & - \\ - & - \\ 220, & - \\ - & - \\ \text { K5. } & - \\ - & - \\ - & - \\ - & - \\ - & - \\ - & -\end{array}$ \begin{tabular}{lr}
- & -360 \\
- & -250 \\
- & -600 \\
- & -90 \\
- & -130 \\
- & -110 \\
- & -400 \\
- & -400 \\
- & -500 \\
- & -300 \\
- & -660 \\
- & -500 \\
- & -160 \\
- & -110 \\
- & -120 \\
- & -90 \\
- & -80 \\
- & -400 \\
\hline & 12,770
\end{tabular} 




\section{WLORULA LOUISVILLENSIS,}

SIVE

Plantamum Catalogus.

VICINITATE IJRBIS.

IENRICO MGMURTRIE, M. D. \&.c.

AIUCCCXIX. 


\section{AUCTORUM NOMINA}

IN HOC OPUSCULO CITATA SUNT.

Ait. - - - Aiton. Hort. Kew.

Brt. - - - Barton. Flor. Virg.

Btr. - - - Bartram. Plant. Catal.

Crt. - - - Curtis. Flor. Londin.

Jus. - - - Jussieu.

Lin. - - Linnæus. Spec. Plant.

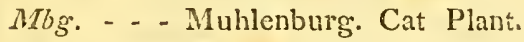

Mrs. - - Marslall. Arbust. Ama.

Nut. - - - Nutall. Plant. Gener. Am.

$M I_{x}$. - - Michaux. Fior. B. A.

Per. - - Persoon. Synop. Plant.

Psh. - - - Pursh.

Raf. - - Rafinesque. Flor. Ludor.

Sth. - . - Smith. Flor. Britt.

Wht. - - - WValter. Flor. Carol.

IVild. - - Willdenow. Sp. Plt. Id.

Scr. - - - Schreber.

Mtr.... (mihi). 



\section{FI.ORULA LOUISVILLENSIS.}

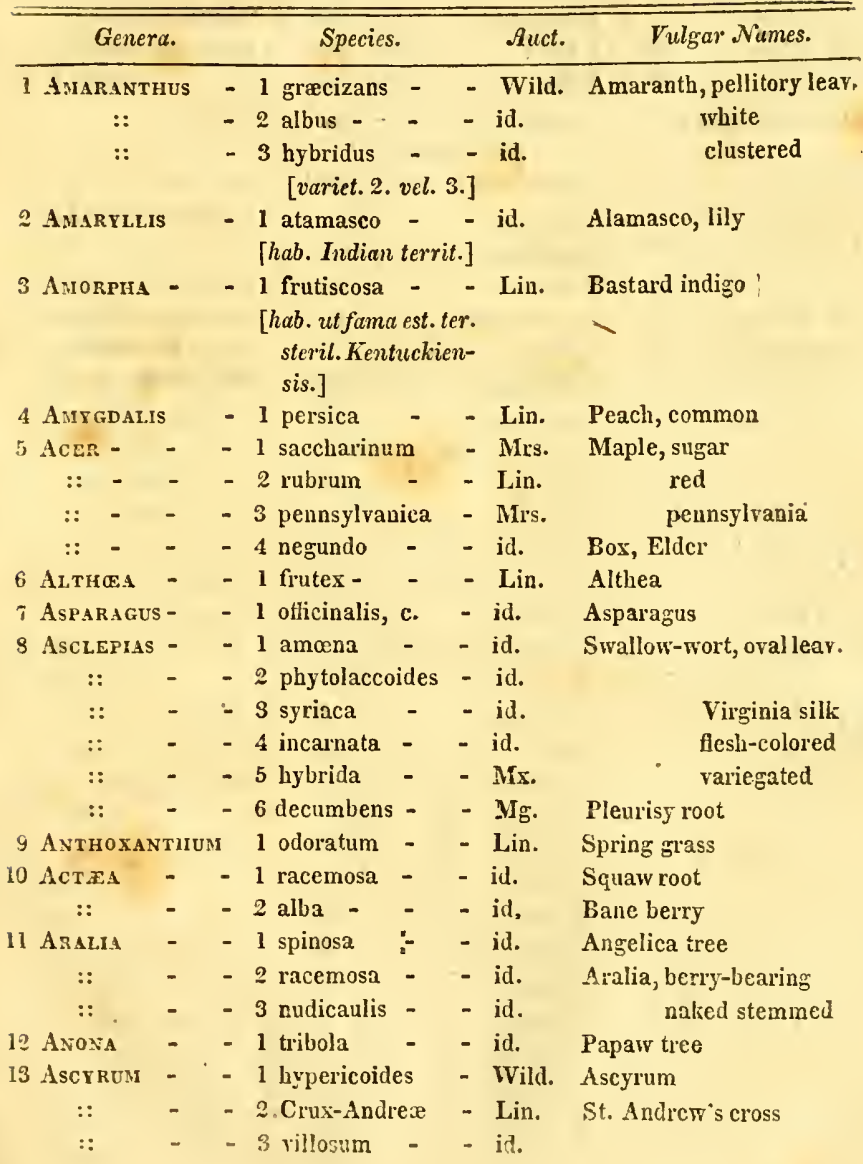




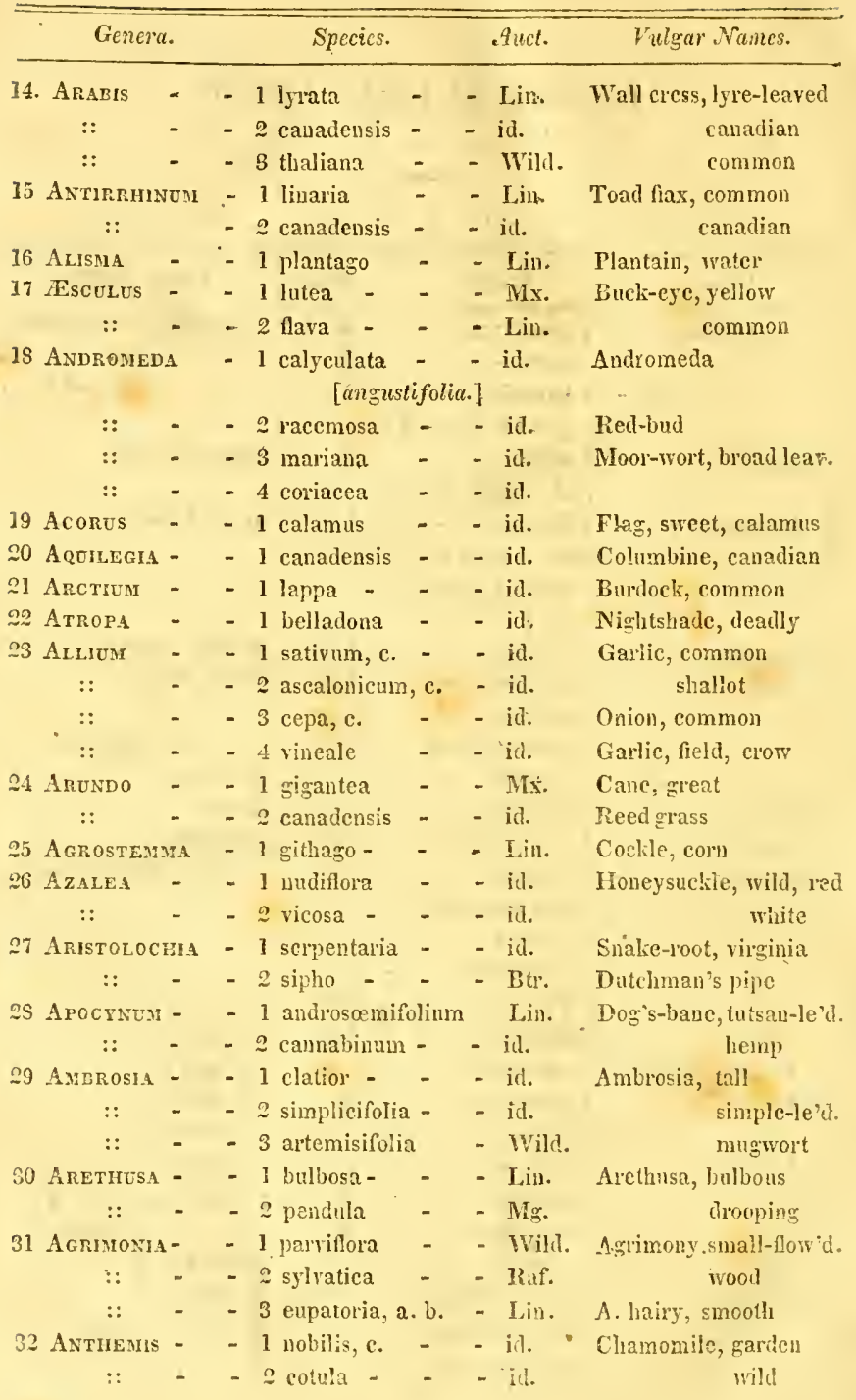




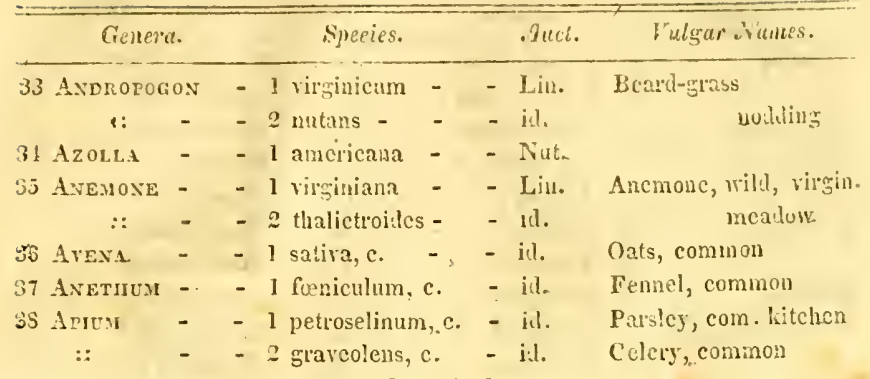

\section{[2 rarict.]}

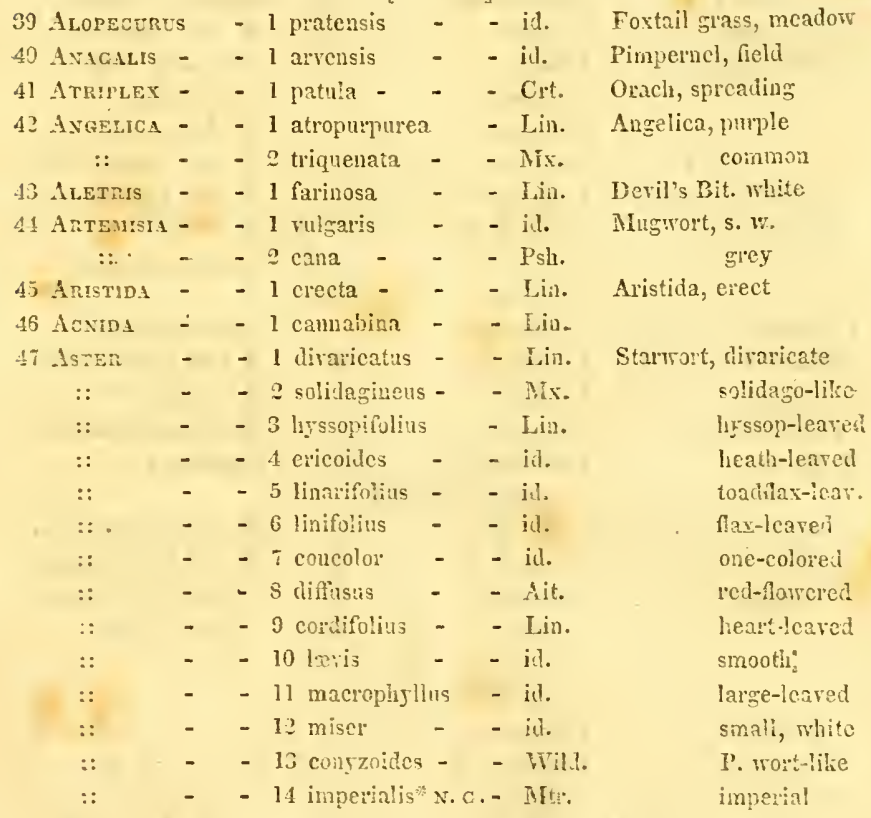

$1 S$ Achitea - - 1 millefolium - - Lin. Inilfori, common

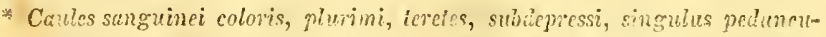

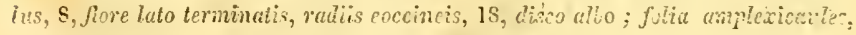

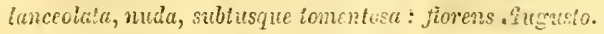

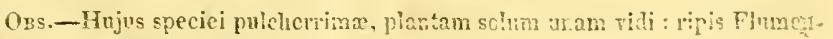
is Cerulei, incians Territorio, me carpeta cst. 


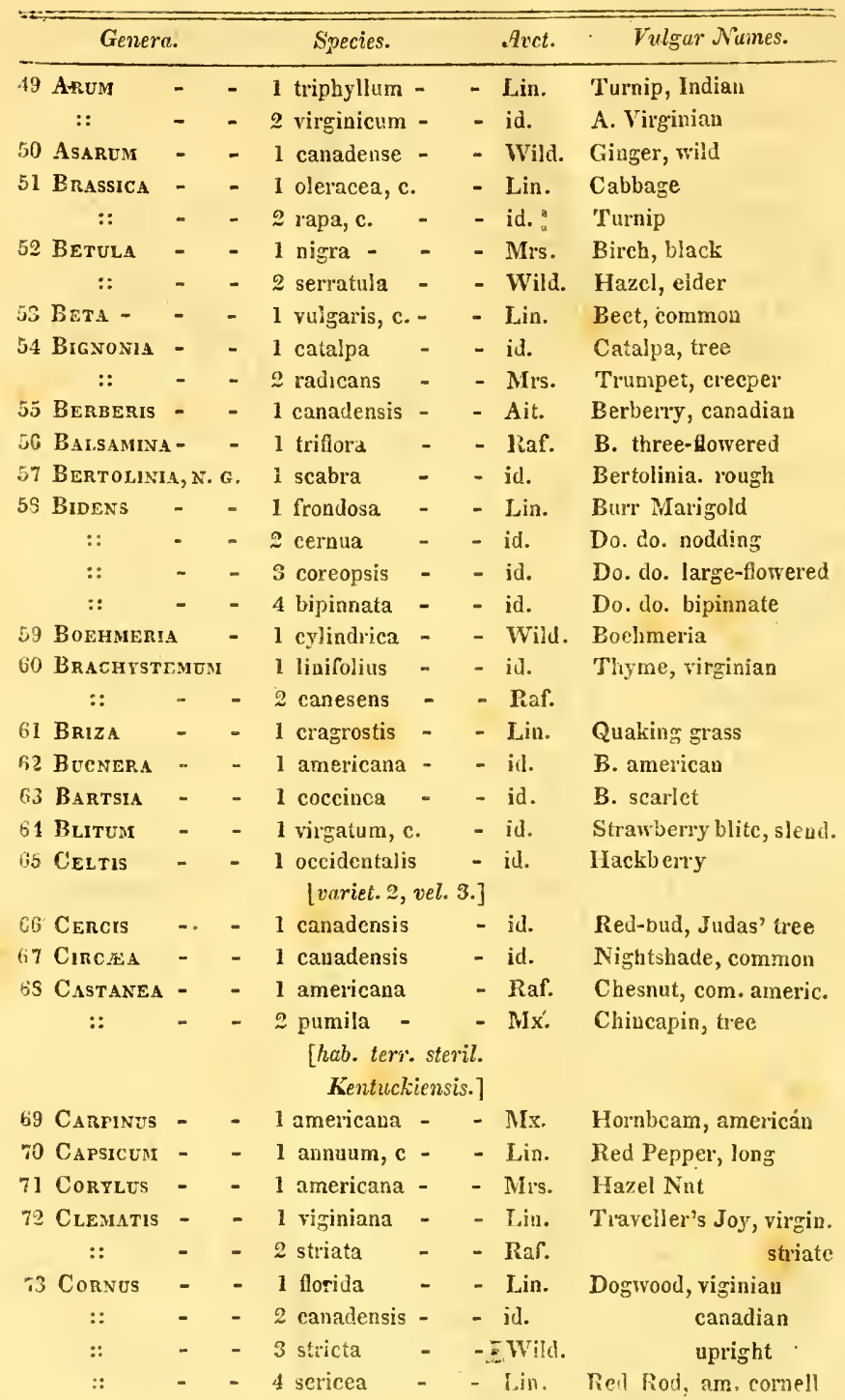




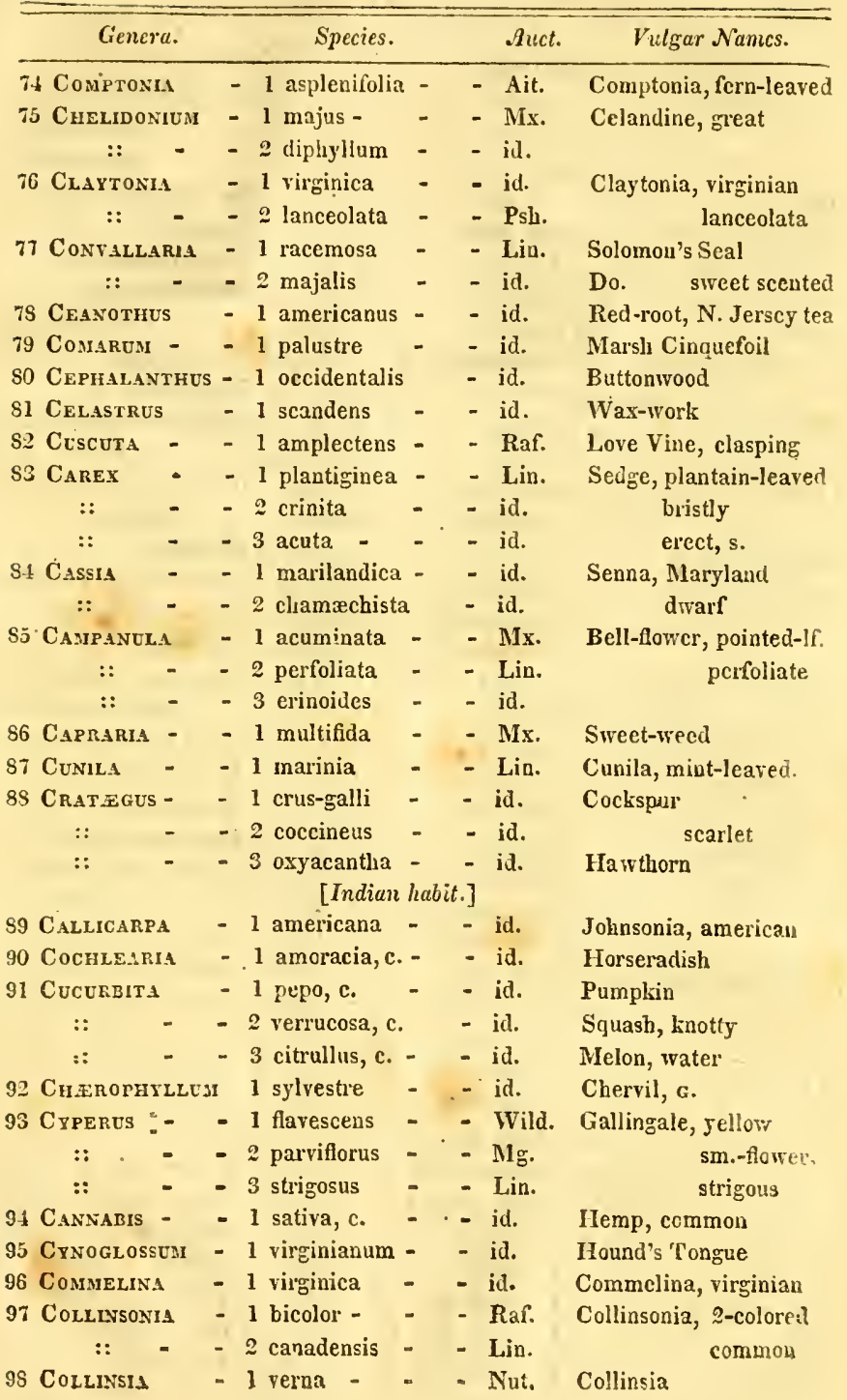




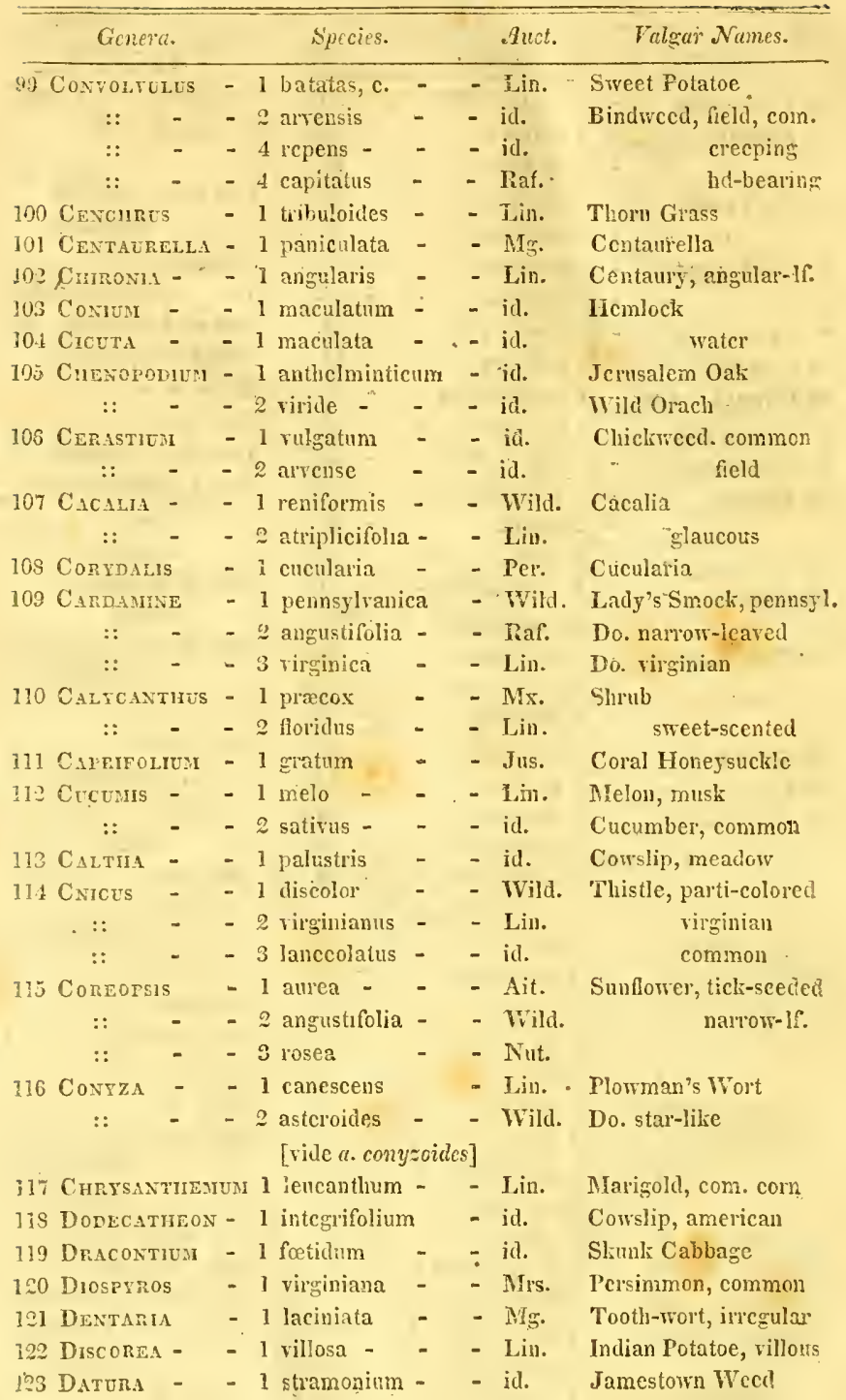




\begin{tabular}{|c|c|c|c|c|c|c|}
\hline \multicolumn{3}{|c|}{ Genera. } & \multicolumn{2}{|l|}{ Species. } & Auct. & Vulgar Names. \\
\hline 124 & 4 Davous & - & - 1 carota - & - & - il. & Carrot, wild \\
\hline 125 & 5 Dirc. & - & - 1 palustris & - & - id. & Leather-wood \\
\hline 126 & 6 Dipsacus & - & - 1 sylvestris & - & - id. & Teazle \\
\hline 127 & I Dracocer & PHAL & LOM 1 virginianum & & - IVild. & Dragon's Head, virg. \\
\hline 125 & Dileptius & & - 1 virginicum & - & - Raf. & Pepper Grass, virg. \\
\hline 129 & Delphinit & LON & - 1 azurcum & - & - Lin. & Larkspur, blue \\
\hline 133 & EPIGEA & - & - 1 repeus & - & - id, & Ground Laurel \\
\hline 131 & Euoxymus & & - 1 carolinensis & - & - Mi's. & Arrow Wood, indian \\
\hline & :: & - & - $\approx$ semperviren & & - id. & Spindle Tree, evergr'n. \\
\hline 132 & Erigeron & & - 1 canadense & - & - Lin. & Fleabane, canadian \\
\hline & $::$ & - & - 2 philhdelphics & um & - id. & philadelph. \\
\hline 133 & Fupatorit & UM & - 1 colestinum & - & - id. & Hempweed \\
\hline & $::$ & - & - 2 agcratoides & - & - id. & nettle-lf. \\
\hline & $::$ & - & - 3 purpureum & - & - id. & purple \\
\hline & $::$ & - & - 4 maculatum & - & - id. & spotted \\
\hline & $::$ & - & - 5 pcrfoliatum & - & - id. & Indian Sage \\
\hline$\sqrt{2}$ & :: & - & - 6 scandens & - & - id. & elimbing \\
\hline 134 & Eriophort & & - i vulgare & - & - Per. & Cotton Grass \\
\hline 135 & Elepilant & TOPUS & s 1 scaber & - & - Lin. & Elcphant's Foot \\
\hline 136 & ELeusine & - & - 1 indica & - & - Mx. & Dog's Tail Grass \\
\hline 137 & Euphorbia & & - 1 maculata & - & - Lin. & Spurge, spottcd \\
\hline & :: & - & - 2 hypericifolia & & - id. & hypéricum-lf. \\
\hline & $::$ & - & - 3 thymifolia & - & - id. & thyme-leaved \\
\hline & $::$ & - & - 4 ipecacuanha & - & - il. & Ipecacuanha, wild \\
\hline 133 & Eltiats & - & - 1 histrix - & - & - id. & Elymus \\
\hline & :: & - & - a ciliate - & - & - id. & fringed \\
\hline$\$ 39$ & ERTsimum & - & - 1 ofticinale & - & - id. & Mustard, hedge \\
\hline 110 & FAGUS & - & - 1 ferruginea & - & - id. & Beech, rusty-leaved \\
\hline 141 & Fraxinus & - & - 1 americana & $\dot{-}$ & - Mx. & Ash, white \\
\hline & :: & - & - 2 quadrangular & ris & - Lin. & blue \\
\hline & :: & - & - 3 sambuci & - & - id. & swamp \\
\hline 112 & Frigaria & & - 1 vesca, c. & - & - id. & Strawberry, garden \\
\hline & :: & - & - 2 virginica & - & - id. & wild \\
\hline 113 & Ferel & - & - 1 villosa - & - & - id. & Fennel, giant \\
\hline 144 & Frasera & - & - 1 verticillata & - & - Brt. & Colombo \\
\hline 145 & G.1Liun & - & - 1 aparinoides & - & - Raf. & Goose Girass, s. \\
\hline & $::$ & - & - 2 circrezans & - & - Mx. & Do. do. cross-branched \\
\hline & $::$ & - & - 3 tinctorium & - & - Lin. & Do. do. dyers' \\
\hline & $::$ & - & - 4 triflorum & - & - Mx. & Do. do. three-flowered \\
\hline 1.15 & Gerardia & & - 1 auriculata & $\sim$ & - Lin. & Fox-glore, wild \\
\hline & :: & - & - 2 purpurea & $\bar{F} f$ & - id. & purple \\
\hline
\end{tabular}




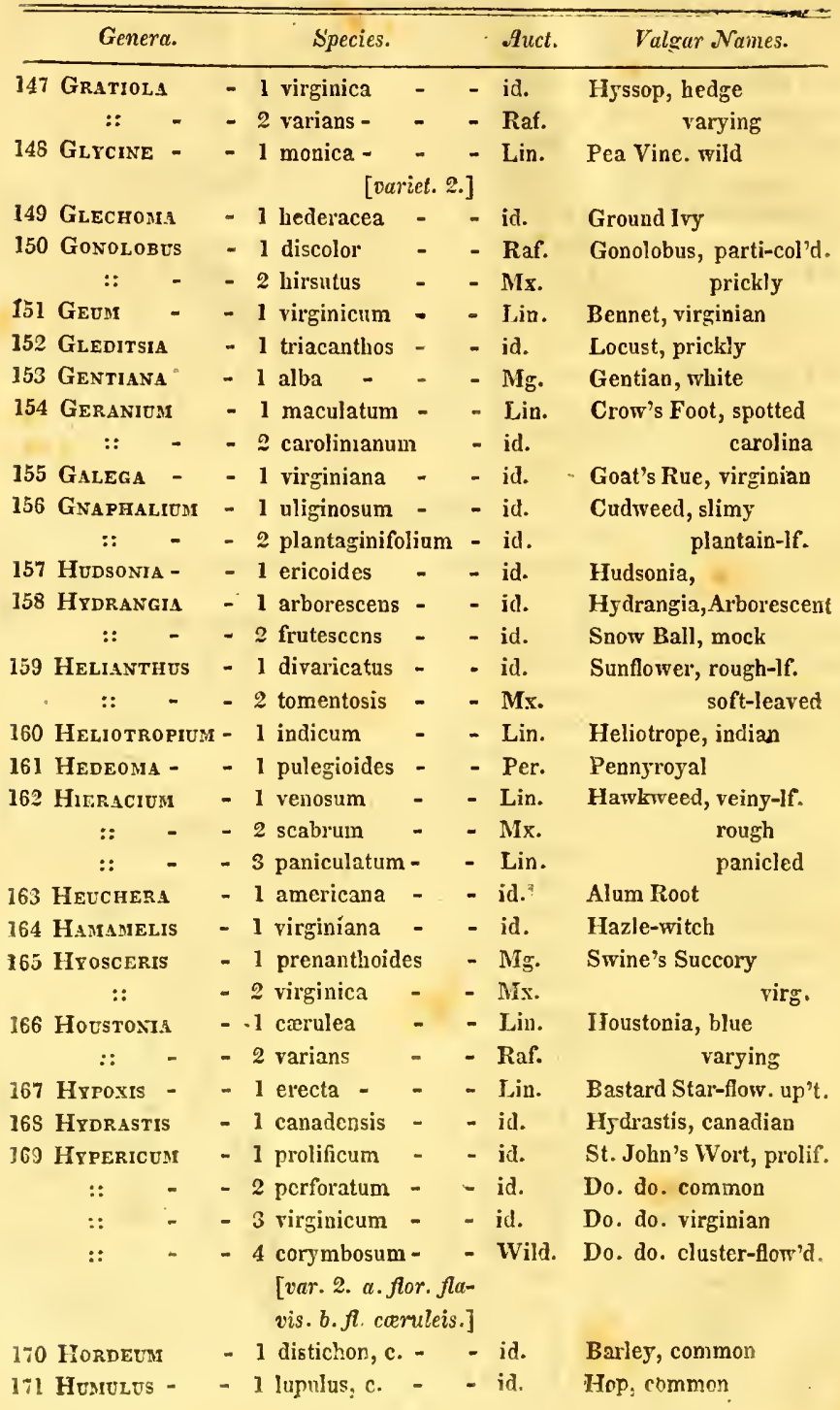




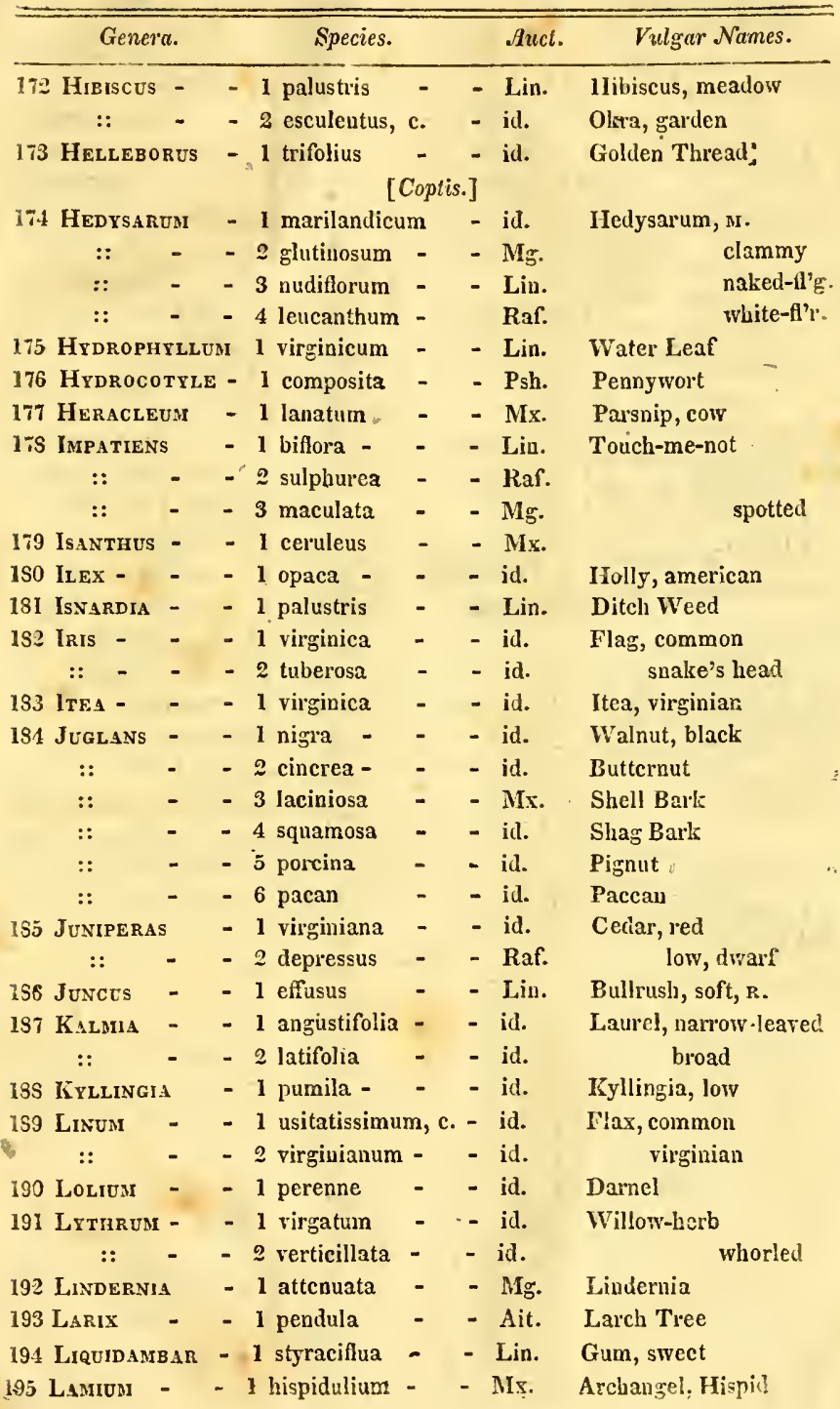




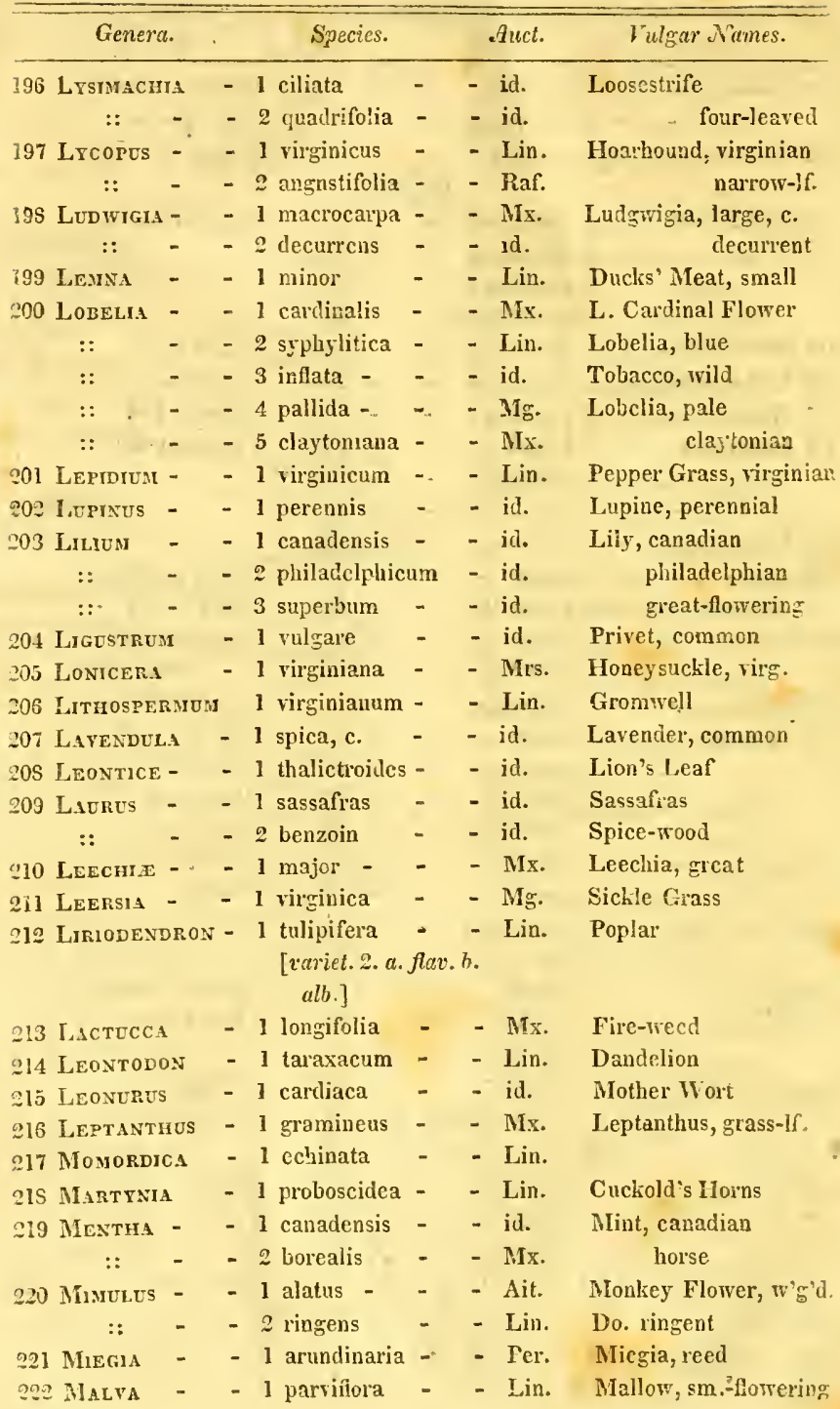




\begin{tabular}{|c|c|c|c|c|c|c|}
\hline \multicolumn{3}{|c|}{ Genera. } & \multicolumn{2}{|l|}{ Species. } & Auct. & Vulgar Names. \\
\hline \multirow[t]{2}{*}{222} & MONOTROP & & - 1 uniflora & - & - id. & Rape Broom \\
\hline & $::$ & - & - 2 lanuginosa & - & - Mx. & wooly, \\
\hline \multicolumn{3}{|c|}{224 MedeOLA:- } & - 1 virginica & - & - Lin. & Cucumber, indian \\
\hline \multicolumn{3}{|c|}{225 Mitchella } & - 1 repens - & - & - id. & Mitchella, cleeping \\
\hline 225 & MORUs & - & - 1 rubra - & - & - id. & Mulberry, red \\
\hline \multirow[t]{2}{*}{227} & Melissa & - & - 1 officianalis, & & - id. & Balm, common \\
\hline & $::$ & & - 2 nepeta - & - & - id. & Calimint, wild \\
\hline \multirow[t]{2}{*}{223} & Mespilus & 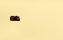 & - 1 arbutifolia & - & - id. & Medlar, red \\
\hline & $:: \quad$ & - & - 2 arborea & - & - Mx. & Pear Tree, wild \\
\hline \multirow{6}{*}{$\begin{array}{l}229 \\
230 \\
231 \\
232\end{array}$} & Mollugo & $=$ & - 1 verticillata & - & - Lin. & Chickweed, indiar \\
\hline & Muhlense & ERGIA & A 1 diffiusa - & - & Per: & Muhleubersia, s. \\
\hline & Melanthi & $10 \mathrm{II}$ & - 1 virginicum & - & Lin. & Melanthium, virginian \\
\hline & MagNolia & & - 1 grandiflora & - & id. & Magnolia, gt.-flowering \\
\hline & $::$ & - & - 2 glauca - & - & - Psh. & Do. sweet swamp \\
\hline & $::$ & - & - 3 acuminata & - & - Mrs. & Cucumber Tree \\
\hline \multirow{3}{*}{$\begin{array}{l}233 \\
234\end{array}$} & Marrubiu & & - 1 vulgare - & - & - Iin. & Hoarhous conumon \\
\hline & Mrosotis & - & - 1 scorpiodes & - & - id. & Scorpion grass, marsh \\
\hline & :: & - & - 2.virginica & - & - id. & virginian \\
\hline \multirow{3}{*}{$\begin{array}{l}235 \\
236 \\
237\end{array}$} & Menianti & UIES & - 1 trifoliata & - & - id. & Trefoil, marsh \\
\hline & Mitella & - & - 1 diphylia & - & - id. & Sanicle, bastd. am. 2 lf \\
\hline & Melampy & RUM & - 1 americanum & - & $-M x$ & Cow wheat, american \\
\hline \multirow[t]{2}{*}{235} & Nrssa & - & - I aquatica & - & - Lin. & Gum tree, large, sour \\
\hline & $::$ & - & - 2 sylvatica & - & - Mx. & black \\
\hline 239 & Nepeta & - & - 1 cataria - & - & - Lin. & Catnip \\
\hline \multirow{2}{*}{$\begin{array}{l}340 \\
241\end{array}$} & Nigella & - & - 1 damascena & - & - id. & Fennel flower \\
\hline & Nicotiano & UM & - 1 tobacum c. & - & - id. & Tobacco, common \\
\hline \multicolumn{3}{|c|}{242 NrMphes. } & - 1 lutea - & - & - id. & Water lilly, yellc w flor \\
\hline & :: & - & - 2 odorata $=$ & - & - Ait. & odorous, virg. \\
\hline & $::$ & - & - 3 adrcua - & - & - Lin. & Splatterciock, common \\
\hline & :: & - & - 4 nelumbo & - & - id. & Nelumbiura \\
\hline \multirow[t]{2}{*}{243} & Oxalis & - & - 1 stricta - & $=$ & - id. & Wood sornel, upright \\
\hline & :: & - & - 2 violacea & - & - id. & violet \\
\hline \multirow[t]{3}{*}{244} & 4 Orchis & - & - 1 spectabilis & - & - id. & Orchis, shewy \\
\hline & $::$ & $=$ & - 2 ciliaris - & - & - Mx. & Do. fringed, wht. \& yel. \\
\hline & $::$ & - & - 3 spiralis - & - & - Lin. & Do. spiral \\
\hline & 5 OROBANC & HE & - 1 virginiana & - & - id. & Beecin Drops \\
\hline & 6 ORONTIUA & & - 1 aquaticum & - & - id. & - Orontium, water \\
\hline \multirow[t]{3}{*}{24} & 17 CENOTHER & & - 1 biennis - & - & - id. & Tree Prinrose \\
\hline & :: & - & - 2 viscosa - & - & - Raf. & Night Willorv Herb, \\
\hline & ;: & $=$ & - 3 sinuata - & - & - Lin. & scollop-leared \\
\hline
\end{tabular}




\begin{tabular}{|c|c|c|c|c|c|c|}
\hline \multirow{3}{*}{245} & \multicolumn{2}{|c|}{ Genera. } & \multicolumn{2}{|l|}{ Spccies. } & \multirow{2}{*}{$\frac{. \text { quet. }}{- \text { id. }}$} & \multirow{3}{*}{ 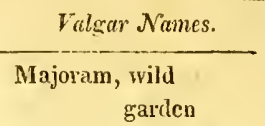 } \\
\hline & ORIGANUA & & - 1 vulgare - & - & & \\
\hline & :: & - & - 2 majorana, c. & - & $-i d$. & \\
\hline 249 & OCYMUм & - & - 1 basilicum, c. & - & - id. & Basil, commor garden \\
\hline 250 & OBOLARLA & $1-$ & - 1 caroliniana & - & - Wlt. & Obolaria, carol \\
\hline 251 & Pliryaia & - & - 1 icptostacliya & - & - Lin. & Plinyma, slcnder spiked \\
\hline 252 & Physalis & - & - 1 penusylvanic & & - id. & Alkekengi, pe \\
\hline 253 & Partileni & IUM & - 1 integrifolumm & & - id. & Feverfew, el \\
\hline 254 & Passiflor & & - 1 lutea - & - & - id. & Passion Flon \\
\hline 255 & Parietar & & - 1 pennsylvanic & & - id. & Pellitory \\
\hline 256 & Pulaionat & R1A & - 1 virginica & - & - id. & Lung-wort \\
\hline 257 & Populus & - & - 1 deltoidc & - & - Mrs. & Cotton Tree \\
\hline & :: & - & - 2 tremula & - & - iil. & Aspen Tree \\
\hline 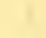 & $::$ & - & - 3 eliliatata & - & - Lin. & Poplar, Lomba \\
\hline & :: & - & - 4 candicans & $=$ & - Ait. & Do. Athenian \\
\hline 258 & Ротаmog & ETON & - 1 lucens - & - & - Lin. & Pond-wecd \\
\hline & :: & $-\quad-$ & - a perfoliatum & - & - id. & Do. perfoliate \\
\hline & $::$ & - & - 3 gramineum & - & - id. & Do. grass-leaved \\
\hline & :: & - & - 4 natans - & - & - id. & Do. floating, broad-If. \\
\hline 259 & Pedicula & & - 1 canarlensis & - & - idl. & Louse-wort \\
\hline 1 & $::$ & - & - 2 lanccolata & - & - Mix. & lanceclate \\
\hline 260 & Phlox & - & - 1 maculata & - & - id. & Phlox, or B. lychnis, sp. \\
\hline & $::$ & - & - 2 pilosa - & - & - id̀. & Do. hairy \\
\hline & $::$ & - & - 3 lavigata & - & - id. & Do. smoot \\
\hline & :: & - & - 4 uniflora - & - & - Raf. & Do. one-flowe \\
\hline 261 & POLEMO & IUN & -. 1 reptans - & - & - Lin. & Valerian, greek, creep. \\
\hline 262 & POLXGo & & - 1 arifolium & - & id. & Kinot-grass \\
\hline & $::$ & - & - 2 erectum & - & id. & upright \\
\hline - & $::$ & - & - 3 barbatum & - & - IVild. & \\
\hline & $::$ & - & - 4 convolvolus & - & - Lin. & Buckwheat, climbing. \\
\hline & $::$ & - & - 5 fagopyrum c & & - id. & Buclswheat, common \\
\hline & $::$ & - & - 6 hydropiperoi & ides & - id. & Water Pepper \\
\hline & :: & - & - 7 sagittatum & - & - id. & Do. arrow-leaved \\
\hline & :: & - & - 8 scandens & - & - id. & Buckwheat, clim'g, am. \\
\hline 263 & Ptelea & - & - 1 trifoliata & - & - Mrs. & Shrub Trefoil \\
\hline 264 & Pxrus & - & - 1 communis & - & - Lia. & Pear Trce \\
\hline & $::$ & - & -2 malus - & - & - id. & Applc Tree \\
\hline & $::$ & - & - 3 cydonia - & - & - id. & Quince Tree \\
\hline & $\vdots:$ & - & - 4 coronaria & - & - id. & Crab-apple Tree \\
\hline 260 & $\operatorname{ILNAN}$ & & M 1 aristatum & - & - Mx. & Mountain Mint \\
\hline & $::$ & $=\quad-$ & - 2 pilosum & & - Nut & \\
\hline
\end{tabular}




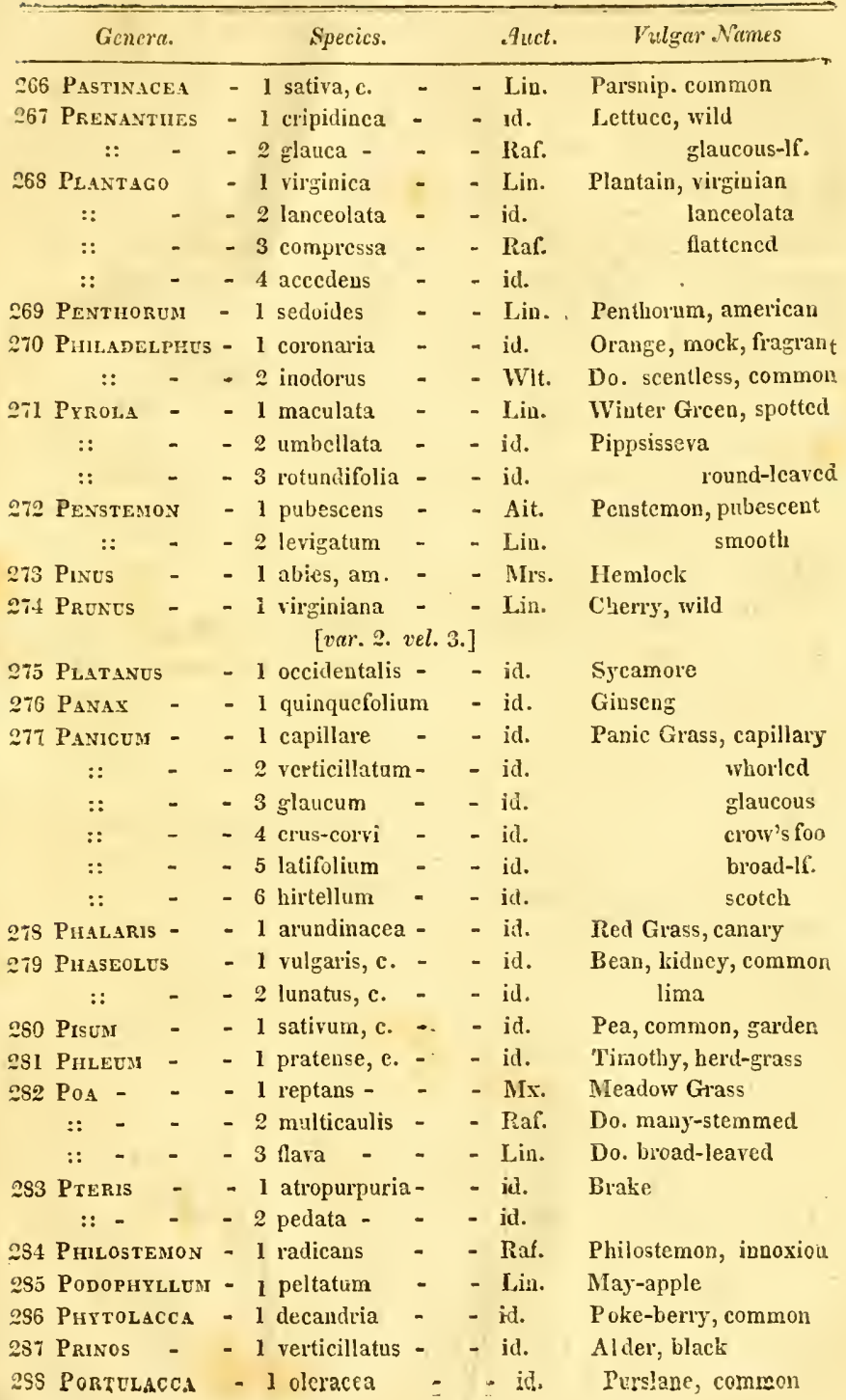




\begin{tabular}{|c|c|c|c|c|c|c|c|}
\hline \multicolumn{4}{|c|}{ Genera. } & \multicolumn{2}{|l|}{ Species. } & Auct. & Vulgar Names. \\
\hline \multirow{3}{*}{$289 \mathbf{P}$} & \multicolumn{2}{|c|}{ POLTGaLA } & - & 1 sanguinea & - & - Lin. & Milk-wort, red-colored \\
\hline & :: & - & - & 2 lutea - & - & - id. & yellow \\
\hline & :: & - & - & 3 senega - & - & - id. & Snake Root, seneka \\
\hline 290 & \multicolumn{2}{|c|}{ Prunella } & & \multicolumn{2}{|l|}{1 pensylvacica } & - Wild. & Self-heal, pennsylvani. \\
\hline \multicolumn{3}{|c|}{291 Paspalumi } & - & 1 læva - & - & $-\mathbf{M x}$ & Paspalum, smooth \\
\hline \multicolumn{3}{|c|}{ 292 Pontederia } & - & 1 cordata & - & - Lin. & Pickerel-weed, heart-If. \\
\hline \multirow{8}{*}{$\begin{array}{l}293 \\
294 \\
295 \\
996\end{array}$} & \multicolumn{2}{|c|}{ Poteriom } & - & 1 sanguiserba & - & - id. & Burnet, conimon \\
\hline & \multicolumn{2}{|c|}{ Potamisia } & - & 1 graveoleus & - & - Raf. & Potamisia, stinking \\
\hline & Papaver & - & - & 1 somniferum & - & - Lin. & Poppy, garden \\
\hline & \multicolumn{2}{|c|}{ Quereus } & - & 1 macrocarpa & - & - Mx. & Oalbburr \\
\hline & \multicolumn{6}{|c|}{ [variet. 3. vel. 4.] } & white \\
\hline & :: & - & - & 3 prinos acumir & inata & id. & chesnut \\
\hline & : & - & - & $4 \mathrm{P}$. monticula & & - id. & rock chesnut \\
\hline & :: & - & - & 5 cineria & - & - id. & upland willow \\
\hline \multirow{3}{*}{-} & $::$ & - & - & 6 tinctoria & - & - Bart. & quercitron \\
\hline & $::$ & - & - & 7 falcata & - & - Mx. & spanish \\
\hline & :: & 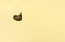 & - & 8 coccinea & - & - id. & red \\
\hline \multirow[t]{4}{*}{2971} & \multicolumn{2}{|c|}{ Rudbeckin } & - & 1 laciniata & - & - Lin. & Rudbeckia, jagged \\
\hline & :: & - & - & 2 luirta - & - & - id. & rough \\
\hline & $::$ & - & - & 3 purpurea & - & - id. & purple \\
\hline & $::$ & - & & $\begin{array}{l}4 \text { amplexifolia } \\
\text { Lplanta rari }\end{array}$ & issin & - Wild. & leaf-clasp'g \\
\hline 998 & Ribes & - & - & 1 oxycanthoide & es, c. & - Mrs. & Gooseberry \\
\hline , & $::$ & - & - & 2 nigrum, c. & $-\quad-$ & - Lin. & Currant, black \\
\hline & :: & - & - & 3 rubrum, c. & - & - id. & red \\
\hline 300 & Ricintes & - & '- & 1 cumunis, c. & - & - id. & Palmi Christi \\
\hline 301 & RAPHANU & & & 1 sativus, c. & - & - id. & Radish, common \\
\hline \multirow[t]{5}{*}{302} & \multicolumn{2}{|c|}{ RanunCules } & & 1 abortirus & - & - id. & Crow's Foot \\
\hline & :: & - & - & 2 bulbosa & - & - id. & Buttercups \\
\hline & $::$ & - & - & 3 flamuloides & - & - Raf. & Spearwort \\
\hline & $::$ & - & - & 4 repens & - & - Lin. & creeping, $\mathrm{r}_{\text {. }}$ \\
\hline & :: & - & - & 5 aquatilis & - & - id. & water, $\mathbf{R}$. \\
\hline 303 & Rumex & - & - & 1 acetocella & - & - id. & Sorrel, sheep \\
\hline & :: & - & - & 2 acuttıs & $=$ & - id. & Dock, sharp, P. \\
\hline 304 & RHODODE & NDRON & & 1 maximum & - & - id. & Rhododendron, great \\
\hline 305 & Rнos & - & - & 1 glabrum & - & - id. & Sumac, red \\
\hline & $:: \quad-$ & - & - & 2 typhinum & - & - id. & stag's horn \\
\hline & $::-$ & - & - & 3 radicans & - & - id. & poison vine \\
\hline & $::-$ & - & - & 4 capallinum & - & - id. & dwaif \\
\hline & $\because:-$ & $=$ & - & 5 suarolens & $\geq$ & - id. & three-leared \\
\hline
\end{tabular}




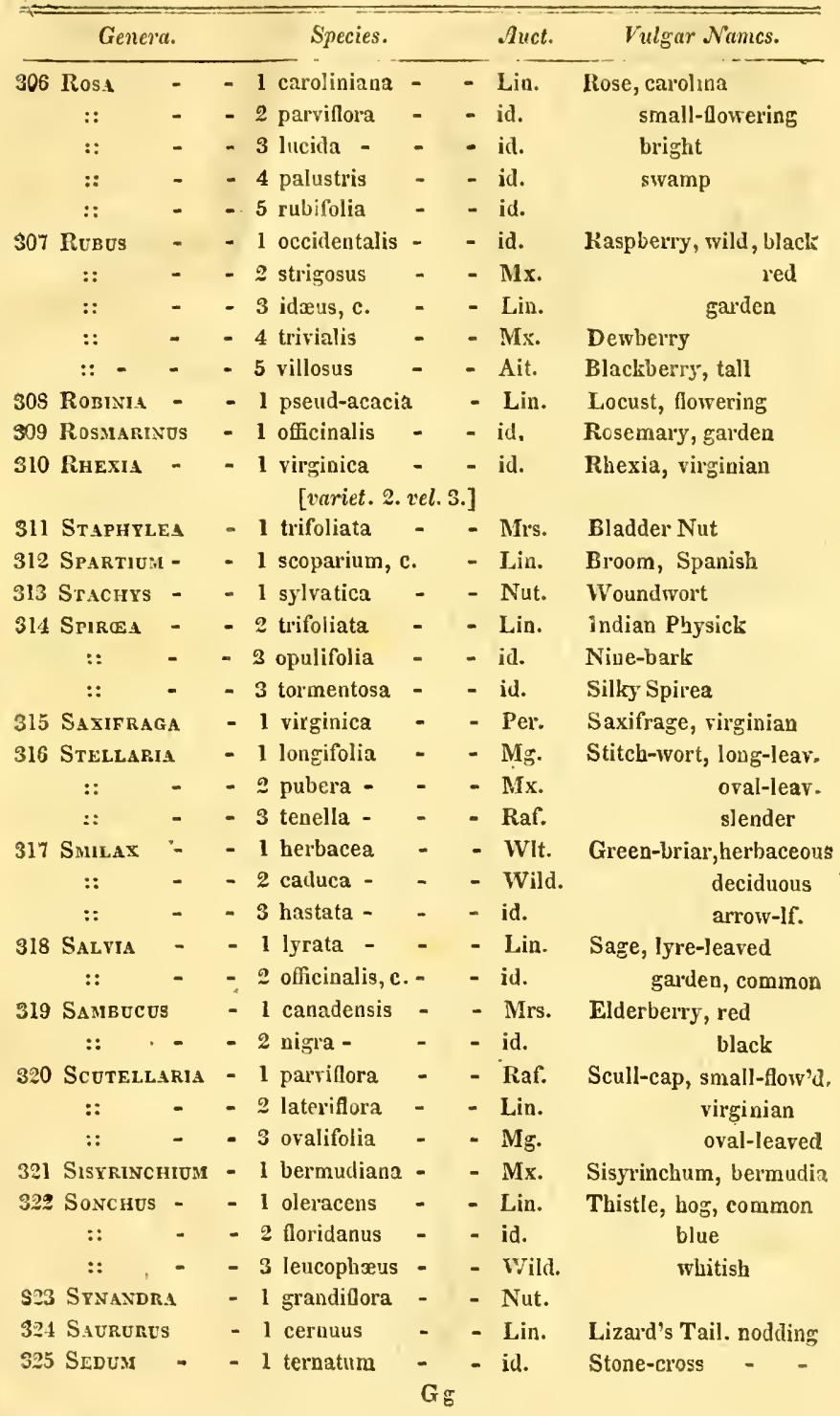




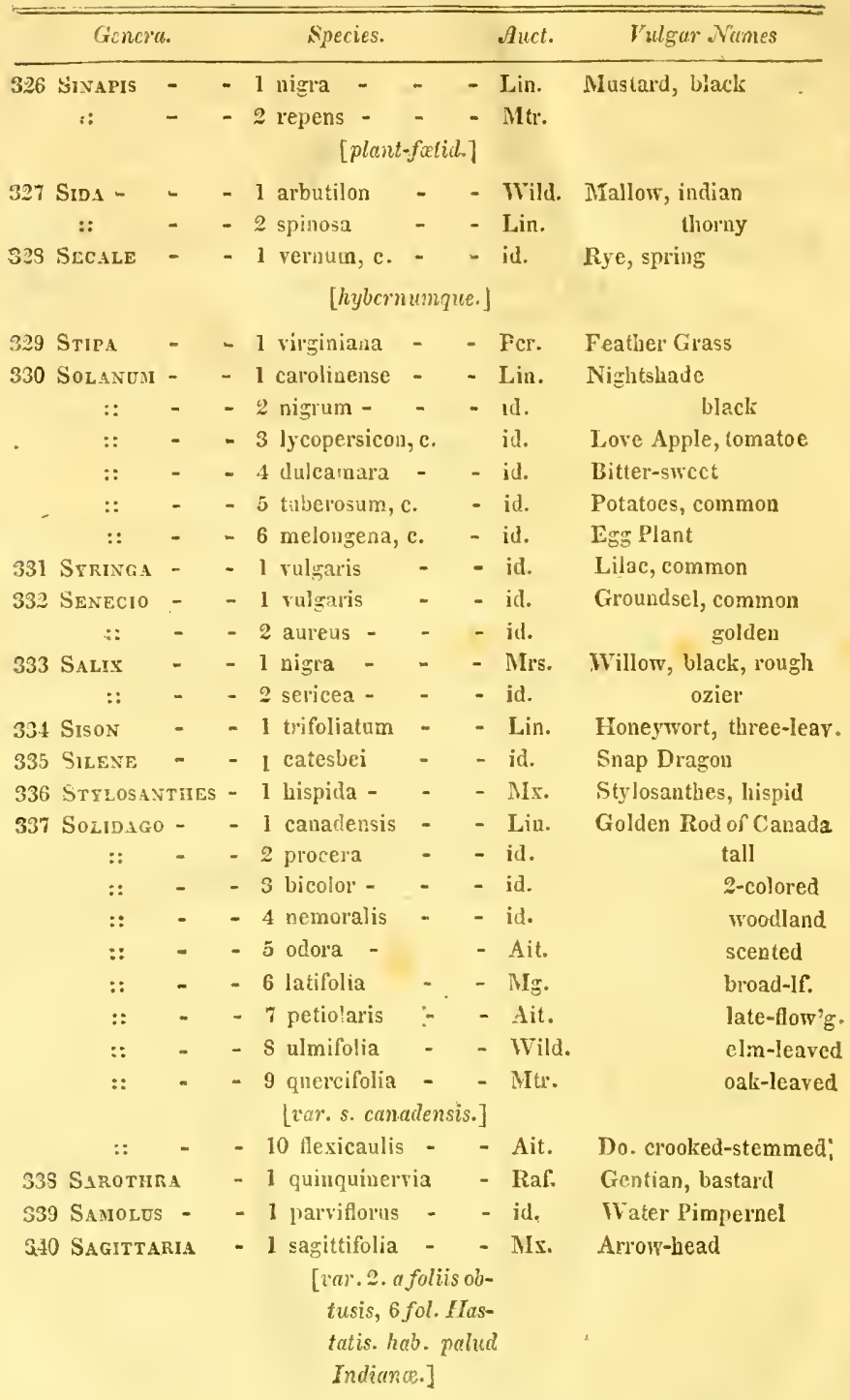




\begin{tabular}{|c|c|c|c|c|c|c|}
\hline \multicolumn{3}{|c|}{ Genera. } & \multicolumn{2}{|l|}{ Species. } & Atuct. & \multirow[t]{2}{*}{ Valgar Names. } \\
\hline 341 & SPARGANIL & UM & - l ramosurn & - & - Sth. & \\
\hline 342 & $\begin{array}{l}\text { SILPHIUM } \\
\quad::\end{array}$ & - & $\begin{array}{l}\text { - } 1 \text { trifoliatum } \\
\text { - } 2 \text { terebiuthace }\end{array}$ & - & $\begin{array}{l}\text { - Lin. } \\
\text { - id. }\end{array}$ & Chrysanthemum, bas. \\
\hline 343 & Sistubrit & & - 1 amptubium & - & - id. & Radish, water \\
\hline 344 & Scrophul & $A R I A$ & - 1 marilandicuı & & - id. & Figwort, maryland \\
\hline 345 & SANGUINAT & RIA & - 1 canadeusis & - & - id. & Puccoon \\
\hline 316 & SPERGULA & & - 1 arrensis & - & - id. & Spergula, corn, field \\
\hline 347 & Scandix & - & - 1 procumbens & - & - id. & Cicely, herb \\
\hline 348 & Sium & - & - 1 latifolium & - & - id. & Parsnip, water \\
\hline 349 & Scirpus, & - & - 1 palustris & - & - id. & Club-rush \\
\hline & $::$ & - & - 2 capillaris & - & - id. & small, capill. \\
\hline & $::$ & - & - 3 maculatus & - & - id. & spotted \\
\hline & $::$ & - & -4 cchinatıs & - & - Mg. & spilied \\
\hline 350 & Scroenus & & - 1 glomeratirs & - & - Lin. & Bog-rush, round-head' \\
\hline 351 & SPIGELIA & - & - 1 marilandica & - & - id. & Pink-1'oot, carolina \\
\hline 352 & SAPONDRI & & - 1 officinalis & - & - id. & Bruisewort, officinal \\
\hline & $::$ & - & - 2 villosa & - & - Raf. & villous \\
\hline 353 & SpINAcia & - & - l oleracea & - & - Lin. & Spinage, common \\
\hline 354 & Thymus & - & - 1 vulgaris & - & - id. & Thyme, common \\
\hline 355 & Tuapsia & - & - 1 trifoliata & - & $=\mathrm{id}$. & Fenuel scorching \\
\hline 356 & Triticum & - & $\begin{array}{r}\text { - } 1 \text { oestivum, c. } \\
{[\text { hybernu }}\end{array}$ & - & - id. & Wheat, summer \\
\hline 357 & $\begin{array}{c}\text { Teucrium } \\
\quad::\end{array}$ & & $\begin{array}{l}\text { - } 1 \text { virginicum } \\
\text { - } 2 \text { canadense }\end{array}$ & - & $\begin{array}{l}\text { - id. } \\
\text { - id. }\end{array}$ & $\begin{array}{r}\text { Germander, virginian } \\
\text { canadian }\end{array}$ \\
\hline 358 & THLAPSI & - & - 1 alliaceum & - & id. & Shepherd's Pur'se \\
\hline 359 & Tecoms & - & - 1 radicans & - & Jus. & Flea-wort \\
\hline 360 & THoxi & - & - 1 occidentalis & - & - Lill. & Cedar, white \\
\hline 361 & Taxus & - & - 1 cauadensis & $\therefore$ & - Mirs. & Yew Tree, canadian \\
\hline $3^{62}$ & Trillium & - & - 1 cernuum & - & - Lits. & Niglitshade, three-lf. \\
\hline 363 & Tripsacua & & - 1 dactyloides & - & - id. & Tripsacum \\
\hline 364 & Thalictu & & - 1 rugosum & - & - Wild. & Meadow Rue, rough \\
\hline & :: & - & - 2 dioicum & - & - Lin. & Do. dioicious \\
\hline 365 & Tilia & - & - 1 americana & - & - Mx. & Linden Tree \\
\hline 366 & Thesium & - & - 1 umbellatuı & - & - Lin. & Toad-flax, bastard \\
\hline 367 & Tradesca & ANTIA & - 1 virginicum & - & - id. & Spiderwort \\
\hline $36 \mathrm{~S}$ & Tanaceto & & - 1 vulgare & - & - id. & Tansey, common \\
\hline 369 & TEPHROSI & & - 1 virgriniana & - & - Per. & Tephrosid, virginian \\
\hline 370 & Trychost & TENA & - 1 dichotoma & - & - Lin. & Trichostema, anuual \\
\hline 371 & TRIFOLIU. & & - 1 repeus & - & - id. & Clover, white \\
\hline & $\begin{array}{l}:: \\
::\end{array}$ & $\begin{array}{l}- \\
-\end{array}$ & $\begin{array}{l}\text { - } 2 \text { pratense, c. } \\
-3 \text { arrense }\end{array}$ & - & - id. & $\begin{array}{l}\text { red } \\
\text { haxe's foot }\end{array}$ \\
\hline
\end{tabular}




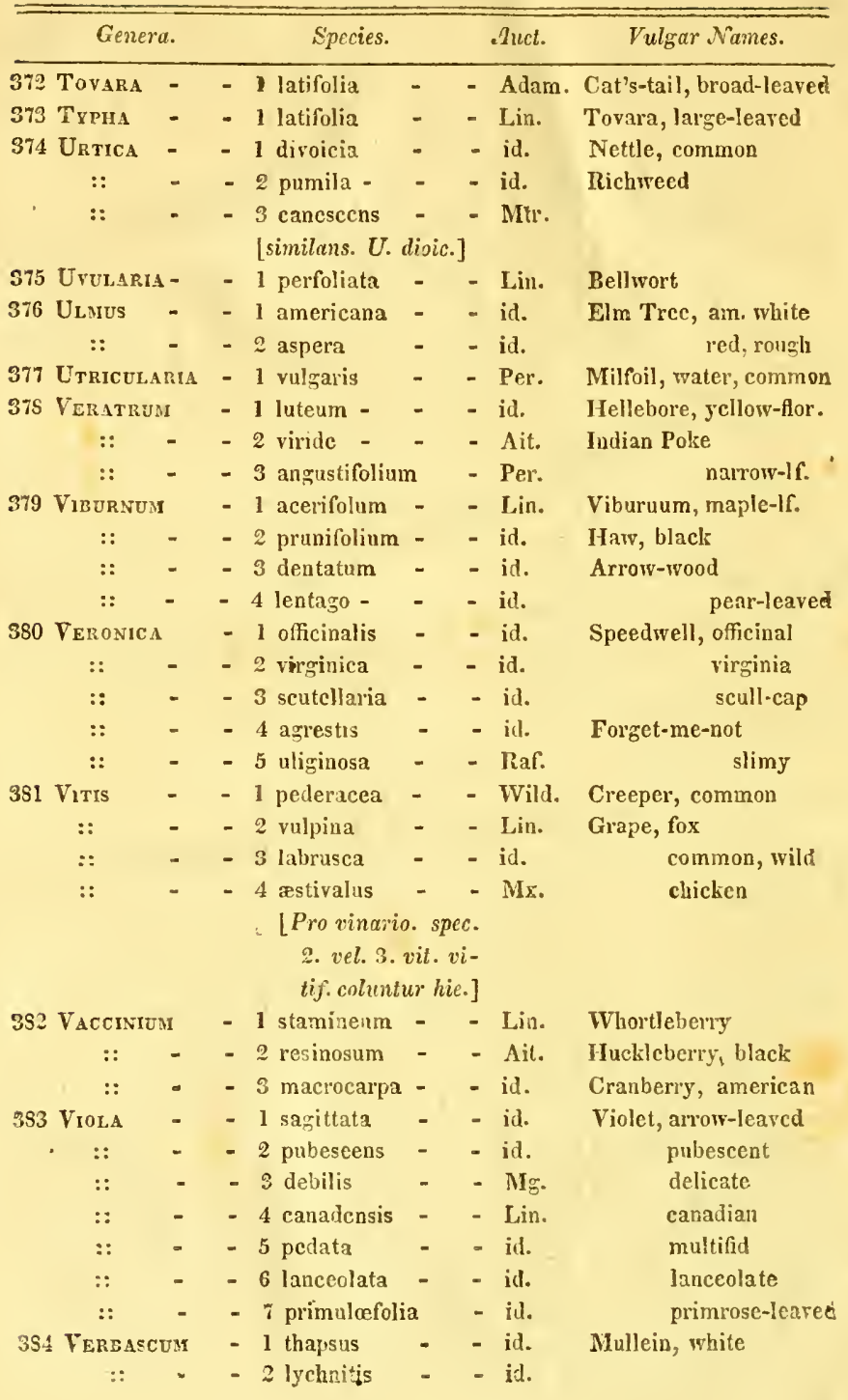




\begin{tabular}{|c|c|c|c|c|c|c|}
\hline \multicolumn{3}{|c|}{ Genera. } & Species. & & Auct. & Vulgar Names. \\
\hline 395 & VISCUM & - & - 1 album - & - 。 & - Mg. & Misletoe \\
\hline 386 & VERBESIN & & - 1 virginica & - & - id. & Verbisina, virgirian \\
\hline 397 & Vicia & - & - 1 americana & - & - Wild. & Vetch, american \\
\hline 358 & VERBENA & - & - 1 paniculata & - & - Lin. & vervain, panicled \\
\hline & :: & - & - 2 urticifolia & - & - id. & nettle-leaved \\
\hline & $::$ & - & - 3 stricta & $:-$ & - id. & erect \\
\hline & :: & - & - 4 caroliniana & - & - id. & carolinia \\
\hline 389 & XanthiUM & & - I struınarium & - & - Lin. & Cockle Burr \\
\hline 390 & XaNTHOX & YLON & - 1 fraxinifolium & & - Mrs. & Ash, prickly \\
\hline 391 & ZANTIIORI & $12 \mathrm{~A}$ & - 1 apiifolia & - & - Lin. & Yellow Root \\
\hline 392 & ZEA & - & $\begin{array}{l}\text { - } 1 \text { mays, c. } \\
{[\text { [variet. } 2 .}\end{array}$ & vel. 3. & - Wild. & Indian Coir \\
\hline 393 & Zarania & - & - 1 nodiflora & $=$ & - & 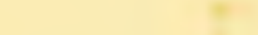 \\
\hline
\end{tabular}

\section{FILICES.}

\section{FERNS.}

\begin{tabular}{|c|c|c|c|c|c|c|c|}
\hline 394 & Adianthun & & - & 1 pedatum & - & - Lin. & Maiden Hair \\
\hline 395 & Asplenium & & $\leq$ & 1 ryzophyllum & & - id. & Spleenwort, root-lf. \\
\hline & $::$ & & - & 2 ebeneum & - & - Ait. & Do. ivory-stalked \\
\hline & $::$ & & - & 3 pinnatifidum & & - Nut. & \\
\hline & :: & & - & 4 scolopendriu & & - Crt. & Do. hart's tongue \\
\hline 96 & Eqisetum - & - & - & 1 sylvaticuin & - & - Lin. & Horse Tail \\
\hline & $::$ & - & - & 2 hyemale & - & - id. & Sliave-grass \\
\hline & Licopodidi & & - & [spec. 5. vel. 6. & & - id. & Club-moss \\
\hline & OSMUNDA & - & - & 1 spectabilis & - & - Wild. & Osmunda, shewy \\
\hline & $::$ & - & - & 2 interrupta & - & $-\mathbf{M x}$ & interrupted \\
\hline & $::$ & - & - & 3 virginica & - & - Lin. & virginian \\
\hline & ONOCLEA & - & - & 1 sensibilis & - & - id. & Onoclea, sensitive fern \\
\hline
\end{tabular}

\section{MUSCI.}

M O S E S.

400 Briom -
401 Fontanalis




\begin{tabular}{|c|c|c|c|c|c|c|}
\hline \multicolumn{3}{|l|}{ Genera. } & \multicolumn{3}{|c|}{ Species. } & \multirow[t]{3}{*}{ Anct } \\
\hline \multicolumn{6}{|c|}{ FUNGI. } & \\
\hline \multicolumn{6}{|c|}{ MUSHROOMS. } & \\
\hline 406 Agaricus & - & - & - & 1 integer & - & Lin. \\
\hline$::$ & - & - & - & 2 campestris & - & id. \\
\hline :: & - & - & - & 3 miptica & - & Raf. \\
\hline 407 Boletus & - & - & - & 1 cinnabarinus & - & Lin. \\
\hline :: & - & - & - & 2 ẋanthorpora & $=$ & id. \\
\hline$\therefore:$ & - & - & - & 3 hematapora & - & Raf. \\
\hline 408 & Pezzia & - & - & - $\quad$ Cup Mu & ushroom & \\
\hline 40 & LICHENE: & & - & [spec. .2. & . vel.3.1 & \\
\hline
\end{tabular}




\section{APPINDIS。}





\section{APPENDIX:}

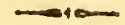

The îrst of those tremendons concussions that shook a great part of the western hemisphere, during the years 1811-12, was first perceived at Louisville on the 16 th December, $1811,2 \mathrm{~h} .15 \mathrm{~m}$. A. M. commencing with about half the strength to which it gradually increased in about one minute; held at tremendons about one minute, then gradually subsided; whole duration, from $31-2$ to 4 minutes; other slight motions follow. $-2, \mathrm{~h} .35 \mathrm{~m}$. A.M.-Moderate mom tion 75 seconds.

7h. $20 \mathrm{~m}$. A. $\mathrm{x}$.-Sudien; violent about 1 minte, then moderated by lessening throes, through the $2 \mathrm{~d}$ and $3 \mathrm{~d}$ minutes to slight tremor; this followed by small and placid motion of about 10 minutes; then severe, stood at that 10 se conds ; gradually subsided, but not to perfect rest ; six considerable shocks are feit during the succeeding 30 minutes; then became constant, and strengthened at a dreadful rate to tremendous, so as to threaten the town with total destruction; duration of greatest violence 1 1-2 min.; moderated in reverse order of approach, but attended with a jarring or strong brisk tremor; it is doubtful if the earth is at rest from these troubles 10 minutes during the day and succeeding night.

Action generally vihratory, horizontal, gentle by, N. West and S. East; time about 80 returns to same point per minute, and uniform, no matter how much the stretch of motion varies. It seemed as if the surface of the earth was afloat and set in motion by a slight application of immense power, but when this regularity is broken by a sudden cross shove, all order is destroyed, and a boiling action is produced, during the continuance of which the degree of violence is greatest and the scene most dreadful ; houses and otherobjects oscilate large $\mathrm{Jy}$, irregulariy, and in differrent directions. - The greatest stretch of motion, whilst regular, was from 4 to 5 inches.

A great noise was produced by the agitation of all the loose matter in town, but no other strange sound was heard; the general consternation is great, and the damage done considerable; gable ends, parapets, and chimnies of many houses are thrown down.

Weather, calm, cloudy, some mist ; temperature, little above freezing.

Dec. $17,1811,5 \mathrm{~h} . \mathrm{A} . \mathrm{n}$. - Shock of considerable force; character of the floating motion before described, duration of greatest strength about one-min.; moderate rain. 
$11 \mathrm{~h} .40 \mathrm{~m}$. A. N.-Sudden, and for an instant violent ; duration 3 minutes; weather clondy, dark, some little sain in the course of the day; also frecquent tremors, at irregular perrods ; evening chilly ; wind flawey; direction unfixed.

1Sth.-Morning, winter cold ; some snow ; frequent but slight shocks duringr the day ; six considerable ones ; wind westerly, light.

19th.-No uncommon motion of the earth perceptible to the generality of people, some are confident there were severalslight shocks during the day and night; winter weather.

20 th. -10 h. 53 m. A. 11 - Calm, freezing, fair; motion had been scarcely perceptible about 5 minutcs, when it arrived to a very considerable strength, and continued, but less violent, until 11 o'clock, and, at interrals, till l.oon and after.-Evening, $S$ o'clock, clear atmosphere except a circle round the moon ; about $90^{\prime}$ clock, frequent slight tremors; warm, calm, orercast; begins to rain at 12 at night.

21st.-10 h. $45 \mathrm{~m}$. A. M.-Slight motion continues from 7 to 8 minutes, and at ofher times during the day-wind from IVest, and considerable.

Sunday 22, Momlay 23, Tuesday 24, Wedresday 25, Thursday 26, Frilay: 27, Saturday 28.-These days are very uniformly of same character; weather generally pleasant, freezino; wind westerly; frequent tremors, or rather a longer motion, each day and night, and mostly between the hours of 8 and 12, by day and by night.

Sunday 29th-Slight tremors fiequent to-day; weather calm, almost fair ; evening ovcrcast, gloomy; some wind, no fixcl direction.

30th.-11 h. A. M.-Considerable motion, and, at other times during the day, tremors ; calm ; dark ; towards crening hcavy mist ; ercning calm ; atmosphere without the least elasticity, one might say dead and brittle; temperature about freczing point.

$31 \mathrm{st}-4 \mathrm{~h} .5 \mathrm{~m}$. A. м.-Sudden shock, violcint; gradually subsiding by lessening throes, in 10 minutes. $-4 \mathrm{~h} .45 \mathrm{~m}$. moderate shock ; rain. J.NuART, 1812.

Wednesday, 1st, 21 m. A. M.-Considerable shock, quickly orer; temperature above freezing ; rain ; morning cold, cloudy ; light wind from S. West ; thm ice.-9h. A. m. slight shock; light snow, but not sufficient to hide the ground ; evening, light breeze from West; tcmperature, scarcely fieczing.9 h. P. м. slight shock, and shortly another; also several slight shocks or tremors during the day and night.

2nd-Morning, winter cold ; light clouds roll rapidly from the West, though litthe wind is felt; weather approaching to fair. $-30 \mathrm{~m}$. P. s. tremor, slight, increases irregularly 5 minutes; then considerable shock about 15 seconds; subsides in the reverse order of approach, several shocks slightly felt during the day.

3d-Cloudy, cold; between S and $120^{\prime}$ clock, A. M. frequent tremor's, some of consideräble strengtì, also frequently during night. 
4th-Tremors like those of yestcrday; fair weather toward the erening. Sumlay 5 , Munday 6 , Tuesday 7 , Wednestay 8-These day's are of the chajacter of the 4 th ; weather moderate, wind small from S. IVcst.

9th.-Pleasant and cold; light wind from West. $3 \mathrm{~h}$. A. . . - - Severe shock of short duration; betwecn 10 and 10 'clock in the day frcquent slight motions, until one is tired of counting them; 24 happen at irregular periods; doubtful if preffectly still one hour to-day.

10th.-Cold screrc ; light wind, S. W ; not perfectly fair at times; atmosphere remarkably pure and agreeable ; slight motions felt frequently throngh the niglit and about the middle of the day ; crening overcast, dense vapour floats. high, small westerly wind. 7 h. P. n. - Motion of considerable strength.

11th. - Extremely cold morning; ice 5 inches, made in a few days. $7 \mathrm{~h}$. A m.-Slight and frequent motions; dense vapour, dispersed about 9 o'clock; wind wcst, light ; from 7 to 9 o'clock, not fire minutes perfect rest of the earth; towards erening cloudy and cold ; slight shock about 9 at night, and one again before daylight.

12th.-Last night suow 11-2 inches deep, very cold morning, approaching to fair; brisknorth-wester, such as are prevalent during winter's generally, but which has not been experienced here this season before; from 9 until 12 at noon frequent and slight motions perceptible ; fair, sunshine, but not melting snow ; towards evening orercast, wird light from west; at 10, P. M. heavy, clondy, wind south, severe cold.

13.-Pleasant winter weather, fair, small wind S. W. 11 l. A. M.-Vibrations begin and continue slightly and almost continually until 12 at noon, then a considcrable shock for an instant, but a tremulous motion continues $30 \mathrm{mi}-$ nutes. 3 h. P. s. - Sudden slight shock, perceptible for about 2 minutes ; evening almost fair ; ground generally clcar of snow ; many people feel a considerable tremor of the earth in the night,

14th.-Morning freezing; $11 \mathrm{~h}$. A. M. a shock generally felt; noon, soft and pleasant brceze from S. IV. ; clear ; sun displays a silvery splendor, and sheds a light of gloomy dusky white; towards evening cloudy; at 9 h. P. s. heavy clouds; light wind, W.S. W. ; growing cold.

15th.-Many corroboraie the fact of there having been several tremors last night; morning, fine weather, small wind, S. IV. soon hazy, snow one inch ; long continuance of vibration and almost without intermission from 11 to 1 'o'clock to-day; others perceptible by the penlulums; evening clear; light unsettled wind.

16th.-Fine winter weather, clear until afternoon; wind S. W. ; evening dark, clouded ; least appearance of tremor or other motions to-day ; some slight motions perceived by the pendulums.

17th.- Snow all day, to the depth only of 2 inches, temperature moderate, wind small and uusettled; doubtful if any motion to-day, until 90 'clock in the evening, one is sensibly fclt: 
18th.-Morning, sleet; considerable motion at $11 \mathrm{~h} . \mathrm{A} . \mathrm{M}$. tremor-like ; vair all day, freezing on the ground; nearly calm ; what wind there is fixed at no point ; evening calm ; if any wind, from north ; clouds secm to rest upon the ground, and reflect the numerous lights from windows and other parts.in strongIy defined columns which stream through each other in every direction, and produce a liandsome but odd sort of scenery, whilst, in about each minute of time, from the beginning of night till after 9 o'clock, flashes of lightening illu. mine the whole; yet such is the density of the fog that one can discern no object through the glare of light unless it be immediately about himself, and it is not perceptible from what quarter the lightening proceeds- the distance must be great; with great attention, a long time in open ground, no report or thunder could be heard; there is no doubt that the cause was very distant.

19th-Weather spring-like, fair; sround cased with icc; soft but blustering wind from S. W. until after noon, then nearly calm; evening cold, least degree of motion to day, but evidently some.

20th-Severe cold, some snow; wind N. W. then north, then N. East, but to day in general, South East, hazy, as little motion to day as yesterday; some say felt one last night.

21st-Extremely cold, hazy, wind varying and small, many say motions were sensibly felt, (a sort of tremor) to day and last night.

22nd-The Ohio has been closed over so that people crossed upon the ice gesterday, just above the falls, where the breadth is more than half a mile; to day the icc breaks and crouds down the declivity with a tremendous crash; the scene is interesting; many who bave boats and cargoes upon the river must suffer. This breaking up, it is presumed, is caused by a spring of some of the southern arms, and by the rain of Saturday, which glided swiftly into the river, over the case of ice which prevented the earth imbibing a drop; wind various and severely cold. During the last 24 bours, several considerable shakes of the earth, attended by a jarring of a peculiar character. Altho' severely cold, in general for several days past, a chilling dampness pcrvadcs the atmosphere, frequent fogs sweep along the surface and glaze every object exw posed, with transparent ice, which is now about a quarter of an inch thick.

23rd-Morning hazy, wind, if any, from South, ground cased with ice $8 \mathrm{~h}$. 50m. A. M. Earthqualie awfully violent, equal to that of the 16 th Dec. at 7 o'clock, and much of same character, duration five minutes, about the middle of that time trcmendous, then did not entirely cease, but continued a kind of tremor ten minutes then strengthened to considerable violence for about one minute, in all, a constant motion was perceivable at least one hour; the damage done to houses is much in addition to that sustained on the 16th ult. $1 \mathrm{~h}$. P.M. and at $10 \mathrm{~h} .30 \mathrm{~m}$. at night very considerable shocks and other tremulous motions frequently perceptible during the night. Immediately after the second shock this morning, it began to rain transparent ice in drops of the size of 
pigeon-shot, for two hours; then moist rain freczing as it fell; then thick snow fell in large featheryflakes; no wind, temperature varying cach hour, but not above freezing. From 2 h. r. ss. rain incessantly until some time in the night. $10 \mathrm{~h} .30 \mathrm{~m}$. P. M. shock of a degree of severity; others, moderate and tremulous, frequent during the night. This is a disastrous tume for navigators of the Ohio who happen to be hereabout upon the River, seven Boats have been seen passing on the falls to day; some with and some without crews on board; no human power can afford relief to the suffercrs, nor can they help themselves but drift on until chance may decide their fate; fortunately, the water is in pretty good state; much howling.and lamentation were heard from a boat enter ing the falls this night, voiecs of men women and children.

24th-Ths morning at break of day considerable shock, between 11 \& $12 \mathrm{~A} . \mathrm{M}$. slight; 15 minutes P. M. considerable, wind S. W. rain, cold, sleet, rain increases; temperature above freezing; shortly before sundown, fog so thick as to obscurc every object at the distance of 100 yards; $8 \mathrm{~h}$. $\mathrm{F}$. M. soft breeze; S. IV. fleeting clouds, betwcen which the moon and stars, now and then, show a splendor of remarkable brilliance; $10 \mathrm{~h} .30 \mathrm{~m}$. P.M. considerable shock (nearly a first ratc) and shortly afterwards two others considerable; continuance of each, about one minute, and slight tremors frequently perceptible; the vibrations this night were generally more rapid than ustual, by a difference of $80 \mathrm{and}$ 120; much rain during the night.

25til-Morning, cold, gloomy, foggy; small wind from north, slight vibrations, rather tremors, perceptible during day and night, at irregular periods.

26th-Morning, sleet mostly wasted, tempcrature aboutequal, dead calm al? day, atmosphere without spring; overcast, dry vapor; frequent tremors at irregular periods during the day and night; night cloudy.

27 th-Just before day many people were alarmed by the motion (in character of tremor.) Morning calm, freezing cold, overcast, smooth dry vapor. Sh $50 \mathrm{~m}$.-Violent shock, as sudden as the arrival of a cannon shot, it gave but one blow, as it were, and was but for an instant severe; gradually subsided and trembled away in about one minute; in two minutes strengthened again to a threatening pitch (slow motion) but soon eased away; a trembling. or jarring continued without cessation until $100^{\prime}$ 'clock, A. M. then, a considerable motion of about one minute; sun shines faintly ; frequent tremors during the day, and, no doubt, almost constantly at a small rate ; temperature, freezing in shade; sun has had little effect on the frost of last night; day, one might say, fair, but the sun sheds a whitish dusky light; gloomy ; evening overcast ; high dry vapour, half transparent, smooth; vertical stars only are seen, they display a brilliant radiance ; wind not sufficient for these $4 S$ hours past to have blown out a candle had it been exposed on the top of a house ; smoke rises in erect colunns to an uncommon height; the animal system disposed to rclaxati on, much complaint on that account; at 10 at night yanor thickens; scme tight wind from south. 
28th. - Fine weather; sun shines all day; a peculiar whitencss of atmospluere ; calm ; small frost last night ; vibrations frequent last night, and all day, particularly from 9 till 120 'clock, A s. Evening fair; at eight o'clock a cicle about the moon ; 9 o'clock slight tremor, then overcast directly; muky, warm, ealm; many stars shine before sundown.

29th.-Morning, rain from 5 o'clock till sun-rise; temperature, little above freezing ; cloudy and calm until near 12 o'clock; from 9 till near 12 at noon almost continual tremor, slight; about $11 \mathrm{~h} .30 \mathrm{~m}$. A. M. severai considerable shocks, one so severe as to alarm the people into the streets and open places; these motions appear to be less rapid than usual ; from 10 to 12 some wind from south, then heavy and boisterous till 20 'clock, lulled towards evening; begins to freeze at sun down; moon shines dimly to-night; many people say sereral shocks were felt at night and onc about day-break.

30th.-Morning, slight frost; wind south and unceasing until 12 at noon; betwecn 9 and 12 o'clock frequent tremulous motrous, some barels perceptible by the pendulum, others considerable ; clouds high, broken, and strongly outlined, floating upon a boisterous solth wind; at 3 P. nr. temperature little above freezing ; the sun seems to have resumel its wonted complexion and majesty, but this long contmued succession of southwardly winds and calms boles no good ; sub-down about freezing cold ; clouds dctached and of strong figure, sucli as one would wish to see after the murky unbroken bue that has generally prevailed ; wind small and flawy ; it may be termed fine weather ; a tremor, with some vibratory action, commences and strengthens to a rate more than moderate, continues with larger and lesser throes for 10 minutes, and Jonger in small motion.

31st.-Morning almost fair ; temperature larely freezing ; last night several slight shocks; from 9 till 12 at noon, almost continual trenor, or longer motion; also afternoon some of considerable rate; wind fiom south; sun shines dimly most of the day.

\section{TEBRUART.}

Ist.-Morning cold, hard frost ; light and broken clouds; wind soutli-east; sun shines dimly at times. 9 h. A. M.-Tremors and slight vibrations commence and continue with but short intervals until about 1 h. P.M.; at that time, fairsun through an atmosphere of whitish complexion; evening somewhat hazy; not a breath of wind.

2nd.-About 2 h. A. M. considerable shock felt by many of the citizens (I did not observe it); from $S$ to 60 'clock, $\Delta \mathrm{sI}$. wind from S. W. heavy, flawy, with stormy rain; about sun-rise ( $6 \mathrm{~h} .54 \mathrm{~m}$.) calm, uncommonly dark and cloudy ; at 10, A. M. sun shines at times ; some flaws of wind from S. W. ; less motion from this morning till noon, than usual of late; hardly perceptible; about 2 r. A. shock sensibly felt; slight motion continues, with short intermissions, until $10 \mathrm{~h} .45 \mathrm{~m}$. P. M. when a slock of considerable strength, then slight and fircquent till $11 \mathrm{~h}, 30 \mathrm{~m}$.. .M. ; began to rain at 50 'clock in the evening: 
$3 d .-50 \mathrm{~m}$. A. M. - Considerable motion, attended witls a sort of tremor; about 6h. A. A. another slight tremor; rained all uight, ceased shortly after daybreak; begins again at \$1. A. N. and continues moderately till 12 at noon; wind cast, north, and W. S. W and blustering; tempcrature, about free zing ; between 12 and 20 'clock, clouds break and float from N. IV.; the sun and atmosphere have a proper complcxion; the citizens felt a slight shock about $2 \mathrm{~h}$. P.s. ; sun-down, good weather; the evening presents the most transparent atmosphere behcld these fifty nights.

4th.-Last night, clear and cold ; ice made l-2 inch ; morning, winter haze, soon dissipated, and sun shone fair ; doubtful if any motion since yesterdiay; atmosphere clear and light; small wind, south. 2 h. P. M.-suddenly overcast ; high and seemingly dry vapor. $4 \mathrm{~h} .30 \mathrm{~m}$. P. sr.-Shock, violent in second degrce, duration one minute ; frequent tremors perceptible one hour before and frequently afterwards; this shock advanced gradually to the greatest strength, and subsided gradually; at that time light puffs of wind from south and a sprinkle of rain ; 100 'clock, P. M. delightful atmosphere, stars sprightly, very cold, wind $\mathrm{W} N$. W. which continued till morning.

5th.-One of the fairest mornings in winter; wind W. N. W. considerable and steady ; cold as great as any yet, ice $11-2$ inch made last night. $5 \mathrm{~h} .30 \mathrm{~m}$. A. M.- Shock of third rate, duration about one minute ; tremors perceptible sometime after. $11 \mathrm{~h} .15 \mathrm{~m}$. A. N. - Vibrators act perpendicularly and strongly nearly one minute, whilst the others scarcely move, then all get into strong action; continuance of this shock (as it may be termed) two minutes. $1 \mathrm{~h} .45 \mathrm{~m}$. P. M.-Whilst at dinner, a shock like that of this morning. 2 h. $37 \mathrm{~m}$. P. M.severe shock, but not of angry motion, duration $31-2$ minutes. $4 \mathrm{~h} .48 \mathrm{~m}$. P. $\mathrm{s}$. after frequent tremors since last shock, another shock of much the same character ; sun-down, light south wind, severe cold, evenirg fair ; from 9 till 11 o'clock dead calm ; at $110^{\prime}$ clock overcast, tuin vapur.

6th.-Clear most of last night ; morning cold, equal to yesterday ; sereral slight tremors during the night; one at break of day; moderate breeze springs from south at $10 \mathrm{~A}$. M. ; no material change during the day; about sun-down, light wind from the east. $8 \mathrm{~h} .30 \mathrm{~m}$. P. M.-Heavy tremors, or rather shock ; other perceptible tremors follow in succession, at short periods; considerable shock at 12 at night ; dead calm ; temperature about freezing point ; a few stars of 1st magnitude only, are seen through a dry vapour.

7th. $-3 \mathrm{~h} .15 \mathrm{~m} . \mathbf{\Delta}$. M. the most tremendous earthquale yet experienced at this place, prece ded by frequent slight motions for several minutes, duration of great violence at least four minutes, then gradualty moderated by exertions of lessening strengh, but continued a constant motion more than two hours, then followed a succession of distinct tremors or jarrings at short intervals, until $10 \mathrm{~h}$. A. s. when, for a few seconds, a shock of some degree of screrity, after which frequent jarrings and slight tremors luring the day, once, at least, in eacls ten minutes; morning clountr, or, annartrtty a dry ranour lay high and unbroken; 
dead calm; began to rain at $20^{\prime}$ clock, P. M. small; 4 P. M. snow in large fea ther-flakes, continues till dark--temperature, mom. 31 , noon 42 , even. 42 . $8 \mathrm{~h} .10 \mathrm{~m}$. P. M. - Shock of secoud-rate violence, and during some minutes two others, at cqual periods, connected by continual tremor of considerable scrcrity; the last shock was violent in the first degree, but of too short duration to do much injury, subsided suddenly, and is followed by constant trembling five minutes, then at intervals till one is tired of counting; the character of these last shocks differs from others, the first shoving in slower time and uniformly, the second more rapid but not so quick as usual (direction by N. W. and S. E.) the third sudden, of angry violence and broken irregular motion. $10 \mathrm{~h} .10 \mathrm{~m}$. P. M. After frequent considerable motions, the shock comes on violent in the second degree, strengthens to tremendous, holds at that about 7 seconds, then trembles away ; severe about five minutes, frequent tremors follow, and a shock of thirdrate violence, 5 minutes after 12 at night; cloudy, some swow on the ground melting fast, calm.

8th.-Frequent tremars follow the shock 5 minutes after 12 at vight, several about day-break; there were not less than 12 of the fifth-rate last night; at: day-break one inch snow, temperature 32 ; horizon brightened, promises a fair mornine, but the rising sun is obscured by a dense vapor which shrouk? the margin and seemed to rise from every quarter. $8 \mathrm{~h}$. A. M. - Temperature 42, haze coutinucl unbrolien until two $0^{\prime} \mathrm{clock}$, although the shape of the sun might sometimes be seen. $9 \mathrm{~h} .25 \mathrm{~m} . \mathrm{r}$ s. - Shock of third-rate, slow motion; calm; overcast, thin transparent vapor; duration of the shock 2 minutes; after 10 o'clock fair weather'; temperature 44 ; sereral slight tremors felt in the night.

9th. - No clouds or vapor dim the splendor of the rising sun, a more bcautiful morning never graces a winter, fair until 2, F. M. but the light appears uncommonly white; calm; at $8 \mathrm{~h} .45 \mathrm{~m}$. A.M. smart shock, with tremors, continues 2 minutes; temperature at sun-rise barely freezing, at noon 46 . $3 \mathrm{~h} .48 \mathrm{~m}$. P.M. a shock like that of this morning, but a rate less severe, fourth-rate continues 3 minutes. High and dry clouds, of no unpleasant aspect, cover the horizon; they drift from the west, while the wind below is from south-east, however there is but little of it. $4 \mathrm{~h} .10 \mathrm{~m} . \mathrm{P} . \mathrm{Mr}$.-Frequent slight shocks and tremors in ten minutes; sun shines; atmosphere seems of the best sort; light and broken clouds lay high. $7 \mathrm{~h}$. r. $\mathrm{M} .-$ All overcast, but heavy looking clouds of some shape, and not that smooth looking vapor so common of late; 8 o'clock fair and elear, pleasant, calı ; some people speak of having felt several slight tremors during the night.

10th.-Just before sun-rise, hazy, barely freczing; at $8 \mathrm{~h} .30 \mathrm{~m}$. A. M. after having been clear and pleasant a few minutes, suddenly overcast, dry rapor', dead calm, smoke descends. $9 \mathrm{~L} .8 \mathrm{~m} . \mathrm{A} \cdot \mathrm{M}$.- - Slight slocks, tremor one minute, then gloomy stnshine. $10 \mathrm{~h} .13 \mathrm{~m}$.-Slight shock; $10 \mathrm{~h} .30 \mathrm{~m}$. another; 11 o'clock, pendulums and vibrators all in smart motion; $11 \mathrm{~b} .20 \mathrm{~m}$. two long 
Tois act fiequently, one-inch in motion at short intcrräis, till $11 \mathrm{~h} .25 \mathrm{~m}$. then for about five minutes large action of the short springs and six-inch pendulum, this motion is very irregular, impulses from curious directions by $\mathbf{E}$. and W. by N. and S. and by N. W. and S. E. cliauging in each few seconds; $11 \mathrm{~h} .45 \mathrm{~m}$. as dead stillness as ever was witnessed; afternoon, frequent slight motions; at sun-down 2 slight shocks in about six scconds ; crening ove:cest, tiin rapor, calm ; temperature, morning 36 , noon 51 , evening 51 . .

20 th. $-8 \mathrm{~h} . \mathrm{A}$. .s. thin high vapor, transparcni; six-inch fontulum in motion, all others still, except small spring, frequent ; $9 \mathrm{~h} .20 \mathrm{~m}$. one-inch pondulum, smart motion, in almost coustant action till 12 o'clock ; sun shines cin$1 y$; wind, if any, from westward ; texp. morning 51 , noon 57 , evening 56.

21st.-Morning, dull weather calm, overcast, diry ; all still until $11 \mathrm{~h} .35 \mathrm{~m}$. A. 3. after which, the shorter vibrators are in considerable action most of the day; 6 h. P. m. still rain, N. E. temperature, morning 52 , noon 50 , crening 50.

22nd.-Rained much during the night; morning, snow, wind N. E.; \&h. $25 \mathrm{~m}$. A. M. shortest vibrators have been frequently in action, and now the six-inch in considerable motion; $10 \mathrm{~h} .5 \mathrm{~m}$. all in motion and continue to act alternately until 11 o'clock, then still, except the short spring, which noves about half the time; ceased snowing - this is the deepest snow we have had, something more than two incies; 3h. P. s. all pendulums, \&c. in action; short ones frequently at other times and in the erening; wind N. W.; sprinlle of snow; there was 2. trembling motion about 12 o'clock last night, which continued abont 10 minutes with various strength, many people were frightened from bod; temperature, morning 42 , noon $3 S$, evening 40

23rd.-Moming, hazs, wintcr-lite appearance; calm, cloudy, very stil? during morning, but not mithout some motion now and then; $11 \mathrm{~h} .25 \mathrm{~m}$. strange actiou of the vibrator, two-inch begins frrst and smartly; in a ferw seconds the four-inch begins, all others stop; then two-inch is set in motion, and they act alternately in quick succession through the whole except the one-inch perdulum, and by separate impulses, from different directions and various strength; the $21-2$ inch spring vibrator did not act for some time, but barely quirered a little--this must be owing to-the paralizing effect of impulses giren quickiy upon each cther, in various directions, that spring now begins and acts largely screral minutes; in 15 minutes all still; repeat frequently, in less measure o: strength, 20 'clock same strange style, and, for the first time to-day, see the onc-iach pendulum in molion; repeat frequently during the day, but for an hour or two at a time at perfect rest; sun shone dimly part of the day; little wiml, S. W.; temperature, morning 39 , noon 10 , evening 39 .

25th.-About midnight considerable shock felt by many people; morning, thick vapor, smooth overcast; 7h. $20 \mathrm{~m}$. A. M. all ribrators in action, like that of yestertay but stronger, fourth-rate at least, continue one hour with varying strength, and frequently during the das; sun shincs dimly part of the time; light unsettled wind, or rather calm; temp. molning $3 S$, noon 43 , erening $4 ?$. 
25th. - Morsing calin, thin vapor about the margins; sun shines all day but climly; between $T$ and 8 'clock, A. s. vibrators and pendulums act as yesterday, but not so strong; some of them are in greater or less unotion most of the day, though less in the afternoon; some light mind from soull; tea:p. morning 4 , noon 59 , evening 55 .

26th.-Morning, appearance like yesterday; motions as the last two clays, but mole moderate; pendulums, se. go on in turn, aut sometimes all at once, almost constantly, until aitcr 12 o' clock, not much rest to-day; wind light, south; clonded up in the afteruoon; began to rain in the night; tempcrature, unorning 48 , roon 49 , evening 56

27th.-ivorning caln, moderate rain, summer-like; from $S$ to 20 'cloci: frequent showers, thunder; south wind, at times brisk; perceive not the least motion until $2 \mathrm{~h}$. $20 \mathrm{~m}$. P. 11. then the $21-2$ and 3 -inch vibrators in consilerable motion, and no other, then all pendulums short of 4 inch act alternately for about 15 minutes; 4 h. 2om. P. s. sprinkle of diy snow; brisk nortli-wester; 7h. $10 \mathrm{~m}$. 2 1-2 spring vibrator in molerate motion 4 minutes; wind west; temp. normins 60, noon 58, evening 48.

2sth.-Last night cleared up cold, icc made; morning N. W. wind, fair; until about 1 o'clock P. N. doubthul if any motion of the middle-length ribrator and pendulum; calm nearly all day; transparent atmospliesc, fine erening; 4erperaturc, morning 42, noon 44 , evenung 42 .

a9th.-Norning tair, frost, fue meather; light wind, IV. N. IV.; it is hoped irom all appearauces that nature had resumed her old stant; 7 . $30 \mathrm{~m}$. A. $\mathrm{m}$ : shock, forrth-rate, acts upon longest pendulums, foating motion, without tremor', short vibrators go some times, and most of them act in turn most of the forcuoon; about $100^{\prime}$ clock sun shines dimis'; $12 \mathrm{~h}$. $20 \mathrm{~m}$. at noon, five-inch pendulum moves inegularly by E. and W. and by N. W. and S. E. others move a little, six-incli some; 1h. P. M. fourth-rate shock, slow motion; shorter pendulums are scarcely affected; din sun; dry, white-looking vapor; the earth has been little at rest to-day; crening tolcrably fair; abont 3 o'clock P. I. shock of third-rate, motion not so placid as the preceding one; temperature, morning 4 S, noon 42 , evening 44 .

Soth.-Morning fair, frost; the day in all like yesterday; pendulums, \&c. more much the same, but no heary shakes, and not many in the afternoon; tenperatnre, morning 38 , noon 44 , evening 42 .

31st.-Norning fair; day much like yesterday, generally more clear, aglecable atmosphere; spring vibrators searcely muve, in perceptible measure, tro or three times, but the lcast motion to-day of any we have had yet; night fain ; teinp. morning, 49 , noon 52 , crening 50.

\section{APRIL.}

Ist.-Fine morning, but thin whitish vapor that in some measure dims the splendor of the sun; light wind eastwardly; rather calm; 7h. 25m. A. N. two; three, and foux-inch penclulums and \& 1-2 iuch spring in smart motion; 104 . 
85m, 1 1-2 inch spring and onc-inch pendulum in action and no others-this seems to be a sort of quarering and throbbing, the stronger motions as often as 35 or 19 per minute, and in pretty regirlar time, and are acting at 11 o'clock (having becu constant); 1h. I. M. middle length pendulum in motion; calm, overcast, smooth; thickening vapor, which continnes all night; many people felt considerable shock in the night; temperatme, morning 43 , noon $5:$, crening 50 .

2nd.-Morning, dark, dry, calm; motions this mornin? and dwring the day like yesteriay, very much; repor dissipa:ed abont noon, but sun shines dimly rest of the day; temperature, moruing 49, noon 53, evening 52.

3rt.-Morning fair; althongh the atmospliere scems transjarcnt throngh the chay, yet the spleador of the sun is rather diminished; some very slight motions like those of yestcrday; from cerroboration of many people, there was a sensible shock about 11 o'clock, fiflh-rate or greater; temperature, morning 16 , ercning 56 .

4th. - Weathex much like yesterday, until about 120 'clock, when orcrcast, thich diry-looking vapor; very small motion to-lay; cloudy evening; light wind, unsettled direction; temperature, morning 54 , noon 64 , ereniug 63 .

5th.-Dark, cloudy, gloomy; motion barcly perceivable to-day by pendulums, Sc. ; generaliy ealm; sprinkle of large light hail about noon; temperature, morning 54 , noon 66 , evening 50 .

6th.-Morning dull and dreary, clouded; pendulums in motion frequently for about one hour from sun-rise, and, alternately, one or more are almost constantly in action till abont $2 \mathrm{P}$. Ar. two lonest do not more at all, dry vapor thickens all day; looks like a gathering stom, but does not feel so; light wind, no settled direction; temperature, morning 49, noon 5:, evening $5:$.

ith.-Morning dreary, orercast, dry; pcndulnms act as yestcrday, motion largest about sun-rise; little at rest to-day, but motion slight aud irregular; generally calm; slight winds, at times no fixed direction; temperature, morning 50 , noon 53, erening 53 .

sth.--Morning dark, eardles required, unless rooms bave the best advantage of window lights, dry; 6h. A. s. tremulous shoctr, fifth-rate, duration 20 seconds; rapor lays bigh in the atmosphere, and thielsens uniil about 11 o'clock; ajpealance speaks rain, the feelings forbid it; fiom 1 till 3 o'clock the boury of the sun slicws, shom of his rays, and is of the moon's complexion; then a shock of third-rate, irregular and mixed motiou, short duration; often suddenly overcast; rlense rapor, as in the inorning; mostly calm; if any wind, from the cast; little rest to-day; about sur-down, pendulums go smartly, except the longer onc; temp. morning 50, noon 55 , evening 55 .

9tb.-NIorning, same smooth-looking vapor shrouds the atmosphere; smali wind at times and shifting; sun slicws dimly for awhile; pendulurns in motion, in smallest measurc, fore part of the day; night innch hile the day, as to weather; temperature, morning 52 , noon $5 s$, ercning $5 s$. 


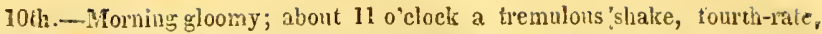
generally folt through the country and torwn; compass would not act for nearly ten minutes; directly a slight sprinkling. of rain; the sun shone dimly a few hours whot highest; temp. morning 56 , noon 58 , evening 56 .

11th.-Morning orereast; light N. W. wind, dry and chilly; between 7 and 3 o'clock pendulums, \&c. in moderate but irregular motion; afternoon the sun shews his sinape dimly, clouds bccoming detached, wind somewhat boisterous; evening, press of wind fress the northward; temperature, morning 40 , noon 49, erening 42.

12th.-Day"much like yesterday, rot much wind; pendulums act slightly at times and least measure; ice made last night; this evening tolerebly fair; temperature, morning 36 , noon 59 , evening 33 .

i3h.- - Klorning, duil weather, dly, cold; smooth overcast, winter-lilie; light north-westwardly wind; ice, thickness of window glass; fuits supposed to. be all destroyed; sun shews dimly about mid-day; pendulums at work at times, but in slight measue, about $90^{\circ}$ clock, A. M.- This is the 120th day of the continuance of the earthcuakes, and, from the maner of moderating, it is to be hoped they will soon cease and lct the carth repose again.-Tcmperature todiay, moiniag 35 , noon 43 , evening 41.

$$
\begin{aligned}
& \text { 14th.-Tem: moin. } 39 \text {, noon } 49 \text {, even. } 56 . \\
& 15 \text { th.-Do. do: } 53 \text {, do. } 65 \text {, do. } 65 . \\
& 16 \text { th.-Do. do. } 65 \text {, do. } 60 \text {, do. } 69 .
\end{aligned}
$$

Character of these diays, generaily, as to rrotion, lite the $13 \mathrm{th}$; wind mostly iv. W. bafling, dry, some heavy purfs.

I'th.-About 11 o'elock last night began to rain; shock at early day light, of fifth-rate, inotion short; rain all day; temp. morning 63; neon 69, erening 66 .

13th.- Tain; penculums fiectuently in action; atmosphere scems to have resuned its wonted elasticiiy, and nature taken her usual course, crccpt 3 tremols; incessant rain by sucessions of heary showers, since Satrrlay crening (16th instant) and particularly to-day; almost as incessant peals of thunder; bigthtening plays in borizontal directions and harmless; 1 bcliove we have not learu so muclı thuacie:, in all, for 12 months, as during the last 48 hours; wind, when any, south-westwerdiy; tomperature, moming 67, noon 74 , ever ing 64 .

19h. - Rain, and some t'sunder; motion as yesterday; tcup. morning 64 noon 65 , evening 63 .

$$
\begin{aligned}
& \text { soth.-Temp. morning } 56 \text {, noor, 64, crening } 63 \text {. } \\
& \text { 21st.-Temp. morning 54, noon } 68 \text {, cvening } 63 \text {. }
\end{aligned}
$$

Some shorrers these two days and slimilit motion of pendulums.

22nd.-Fair wcather botweer 6 and $100^{\prime}$ clock, \& M. consicierible motions and frequent, to maire half ite, time up; saens to be still during middle part of the day; wind soutlerly; $10 \mathrm{r}$. M. short pendulum and all springs in sma!l mo. tion; temperature, morning $5 \%$, noon $S 3$, evening 22. 
23rd.-Temperature, mo!ning 62, noon 6.1, evening 61.

S-th.-Temperature, morning 56 , noon 76 , evening $7 \%$.

85th.-Temperature, morning 66 , noon 80 , evening 71 .

26th.-Tcmperature, morning 62, noon 72, evening 72.

27 th.-Temperature, morning 59, noon 72 , evening 69.

Motion of pendulums each of these days, and some not very small; fair weather since late thunder showers, and dry; but the vapor commonly hangs in the atmosphere yet.

28th. - Shortly before day-break, a shock of about fourth-rate; calm; between 7 and 10 A. M. vibrators act largely; cvening looks like the times of carthquakes; calm, generaily, thesc days; temperature, morning 64 , noon 72, erening 70.

! 29tis-Morning dry, vapor, calm; vibrators in motion; evening, motion slight; rain and thunder this evcning; temp. morning 79 , noon 50 , evening 80 .

30th.-Thunder and frequent shower's of rain during the day and night; wind. from all points; motion of pendulum and vibrator fore and latter part of the day; temperature, morning 72, noon 74, evening $7 \%$.

AIAY.

Ist.- Much rain last night and moderately all day; wind $\mathrm{E}$. and N. E.; increased action of vibrators, \&c. ant I believe they were in motion most of the day; people speak of feeling earthquakes frequently; temperature, morniug 63 , noon 68 , evening 65 .

2nd.-Eight o'clock, A. M. pendulum in motion; frequent showers of rain; abont 3 P s. violent storm, heavy thunder; west wind generally to-day; pendulurns not still at sun-down; temperature, moning 65 , noon 74 , crening 70 .

3rd.-Murning, some thunder; rainy day; wind, various courses; motions of pendulums in fore and latter part of the day; temperature, morning 54 , noon 52 , evening 51.

4th.-Morning, appear's to threaten rain; at 8 o'clock the pendulums in motion; ffeeting ciouds; small wind at times W. N. W.; 10h. 251n. shock, thirdrate, strengthens and lessens three times, second strongest, duration 4 minutes; weedle indicated the approach several secords before the motion was felt; stopped on the bank of a deep pond, the surface of which was a perfect mirror to appearance, overhung by lofty trees, it instantly assurned the dull complection and secmingly the roughness of a file; conrerging wares were soon raisect by the quick motion of the shores, and, contending with each other, caused a curious commotion; the noise produced by the agitation of the trees resembled tivat of a shower of small hail in the forest; before 30 'clock P. M. 2 other slight shakes so that the compass would not serve for several minutes; about $30^{\prime} \mathrm{clocl}$ : light shower of hail and rain; wind N. WV.

5th.-Fine weather, except too cold for the season; frost last night; pendulums and vibrators in motion frequently and principally from $7 \mathrm{~h} .10 \mathrm{~m} . \mathrm{A} \cdot \mathrm{MI}$. and some in the evening; temperature, morning $43,1000 \mathrm{6} 66$, crening 50 . 
The principle that these earthquakes are simultanecus tiroughont and to the exient of the circle of action, may be safely founded upon the following scale of time applied to three of them of the first-rate.

Time at the instant, three o'clock, Pichmond, Virginia; time at each of the other places here named, under that meridian, as a departure restward, is as follows, or as nearly so as need be reckoned for the present purpose. This scale embraces about 10 degrees latitude and about 15 degrees longitude, ant? it is presumed the scope is sufficicnt althongh it is far outreachcd by the extension of the object.

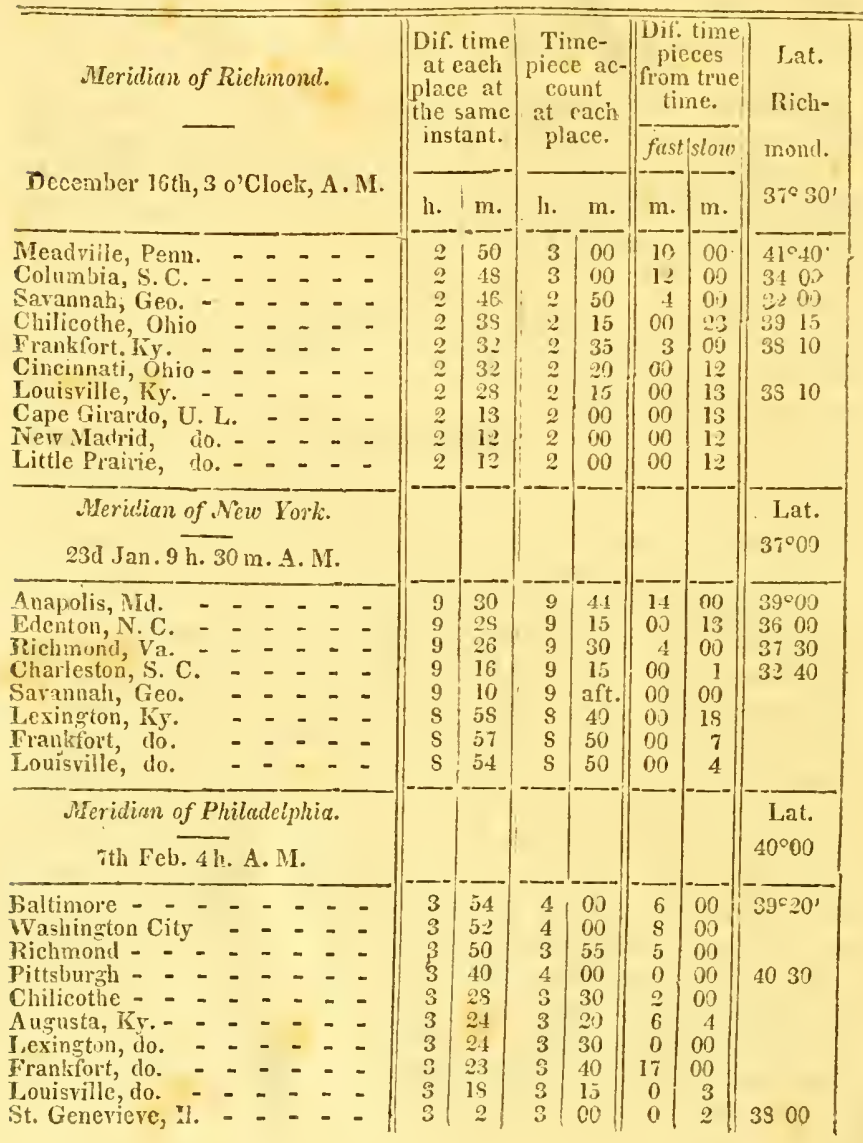


Problably some of those who noticel the time counted from the beginning of she shock, others from the tine it ccascd, but upon the whole they agrce pret1) well.

From the forcyoing statement the following scale of the classification of the difierent rates of violence has been constructed.

First-rate, most tremendious, so as to threaten the destruction of the torrn, and which would soon effect it, should the action continue with the same degree of violence, buildings oscillate largely and irregularly and grind against cach other, the walls split and begin to yield, chimncy', parapets and gableends, break in various directions and topple to the ground.

second-rate, less violent, but severe.

Third-rate moderate, but alarming to people gcnerally.

Fonrth-rate perceptible to the feeling of those who are still and not subject to other motion or sort of jarring that may resemble this.

Sixth-rate-although of ten causing a strange sort of sensation, absence, and sometimes giddiness, the motion is not to be ascertained possitively; but by the vibrators or other objects placed for that purpose, on accidentally.

\section{ABSTRACT}

Nrumber of shocks of different rates experienced during each term of seren days for 13 weeks, commencing 16 th December, 1811.

\begin{tabular}{|c|c|c|c|c|c|c|c|c|}
\hline \multirow{2}{*}{\multicolumn{2}{|c|}{ End of each week. }} & \multicolumn{6}{|c|}{ Numbers and Rates. } & \multirow[b]{2}{*}{ Totai. } \\
\hline & & $\begin{array}{c}\text { Ist } \\
\text { Rate. }\end{array}$ & $\begin{array}{r}\text { ind } \\
\text { Rate. }\end{array}$ & $\begin{array}{l}3 \text { rd } \\
\text { Rate }\end{array}$ & $\begin{array}{c}\text { 4th } \\
\text { Rate. }\end{array}$ & $\begin{array}{c}5 \text { th } \\
\text { Rate. }\end{array}$ & $\begin{array}{c}6 \text { th } \\
\text { Rate. }\end{array}$ & \\
\hline 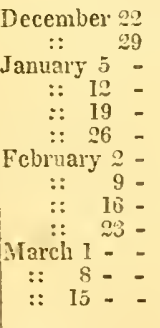 & 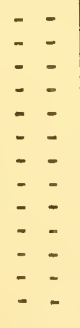 & $\begin{array}{l}3 \\
0 \\
0 \\
0 \\
0 \\
1 \\
1 \\
3 \\
0 \\
0 \\
0 \\
0 \\
0\end{array}$ & $\begin{array}{l}2 \\
0 \\
1 \\
1 \\
0 \\
1 \\
0 \\
5 \\
0 \\
0 \\
0 \\
0 \\
0\end{array}$ & $\begin{array}{l}3 \\
0 \\
2 \\
0 \\
0 \\
7 \\
4 \\
7 \\
3 \\
4 \\
1 \\
2 \\
2 \\
2\end{array}$ & $\begin{array}{r}1 \\
0 \\
9 \\
10 \\
4 \\
2 \\
6 \\
5 \\
6 \\
6 \\
4 \\
9 \\
3\end{array}$ & $\begin{array}{r}12 \\
6 \\
3 \\
0 \\
6 \\
2 \\
7 \\
15 \\
12 \\
4 \\
5 \\
8 \\
6\end{array}$ & $\begin{array}{r}66 \\
150 \\
119 \\
150 \\
55 \\
78 \\
191 \\
140 \\
65 \\
275 \\
126 \\
39 \\
210\end{array}$ & $\begin{array}{r}87 \\
156 \\
134 \\
161 \\
65 \\
91 \\
309 \\
175 \\
86 \\
292 \\
139 \\
55 \\
221\end{array}$ \\
\hline & & $S$ & 10 & 35 & 65 & 89 & 1667 & 1574 \\
\hline
\end{tabular}








\section{s r te}

, 2

\section{4.}

$2+2+2+2$

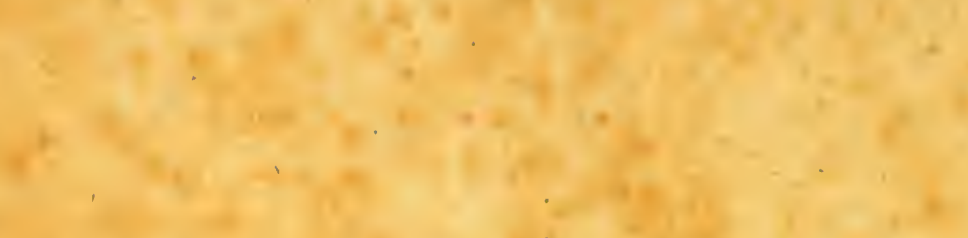

4

4

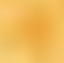

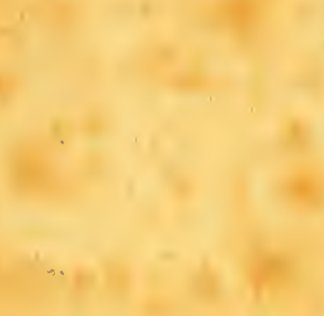

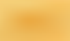
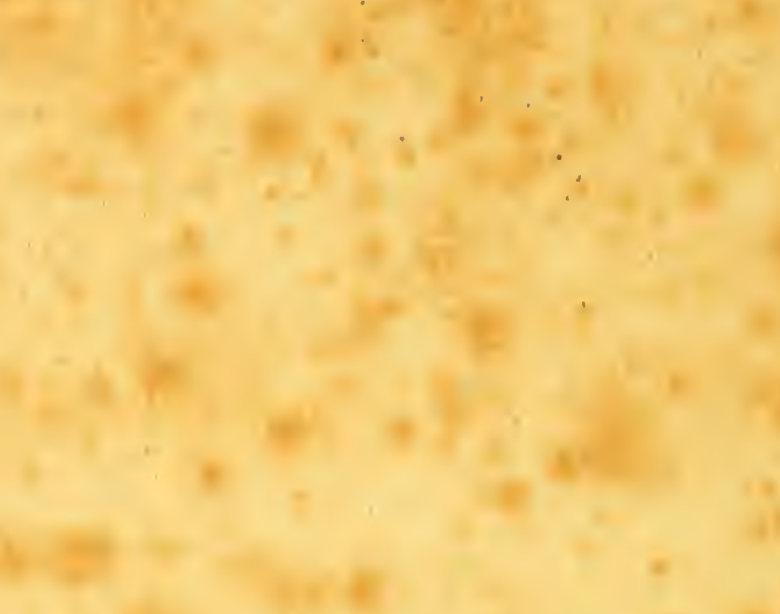

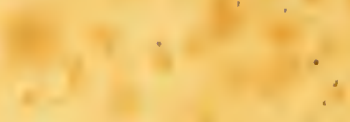

(

7

r

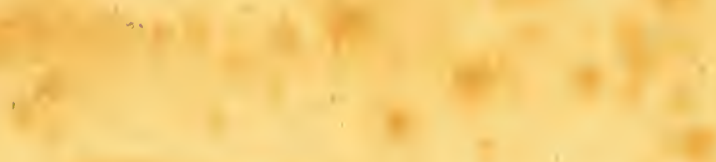

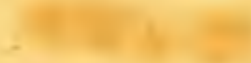

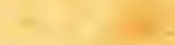

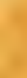

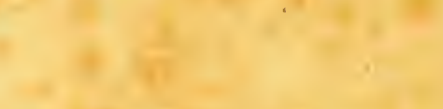

(2)

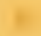

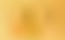

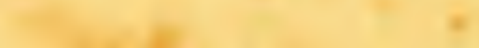

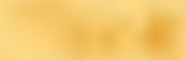

a
$+$

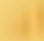

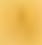

$+$ 


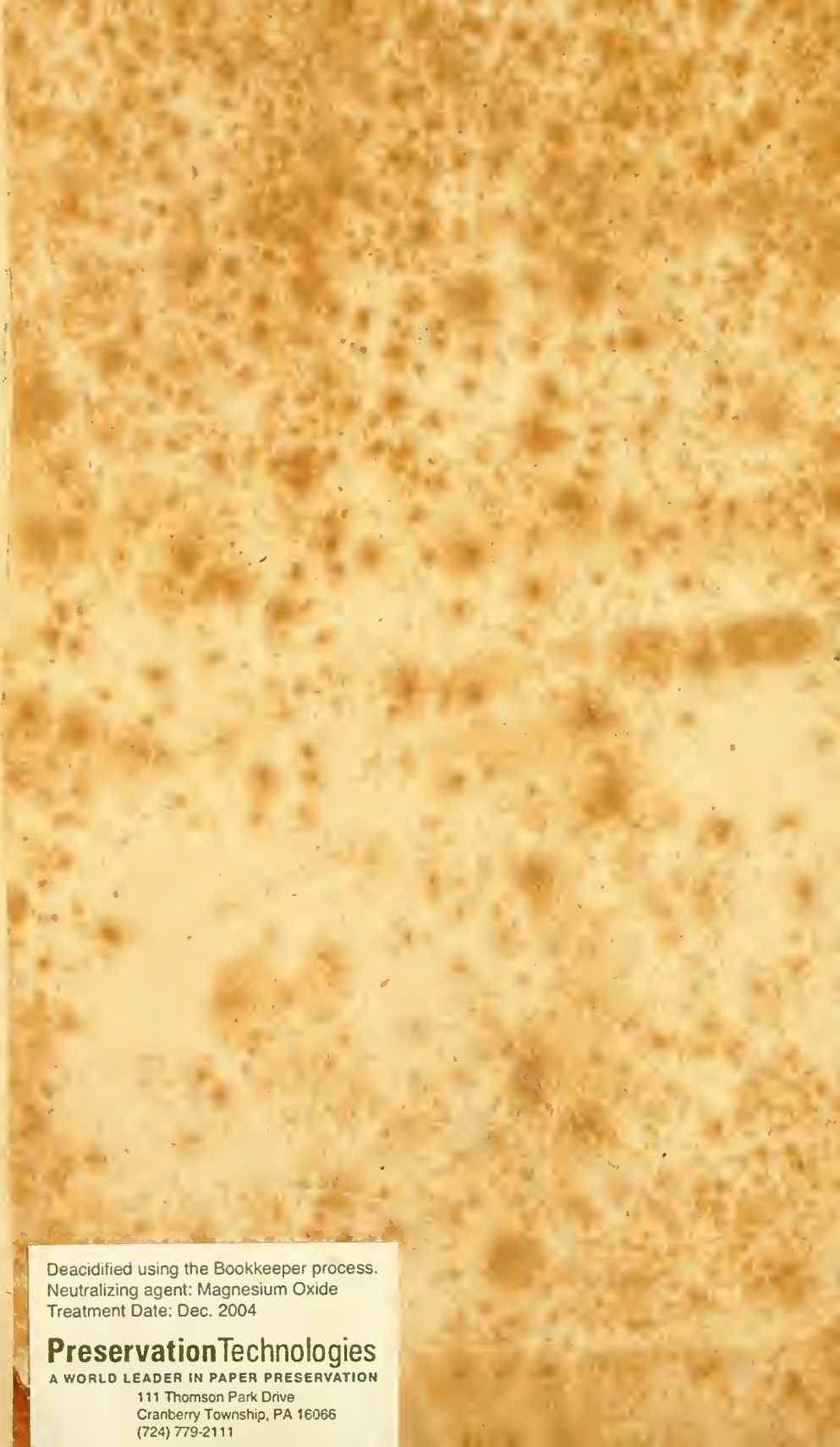



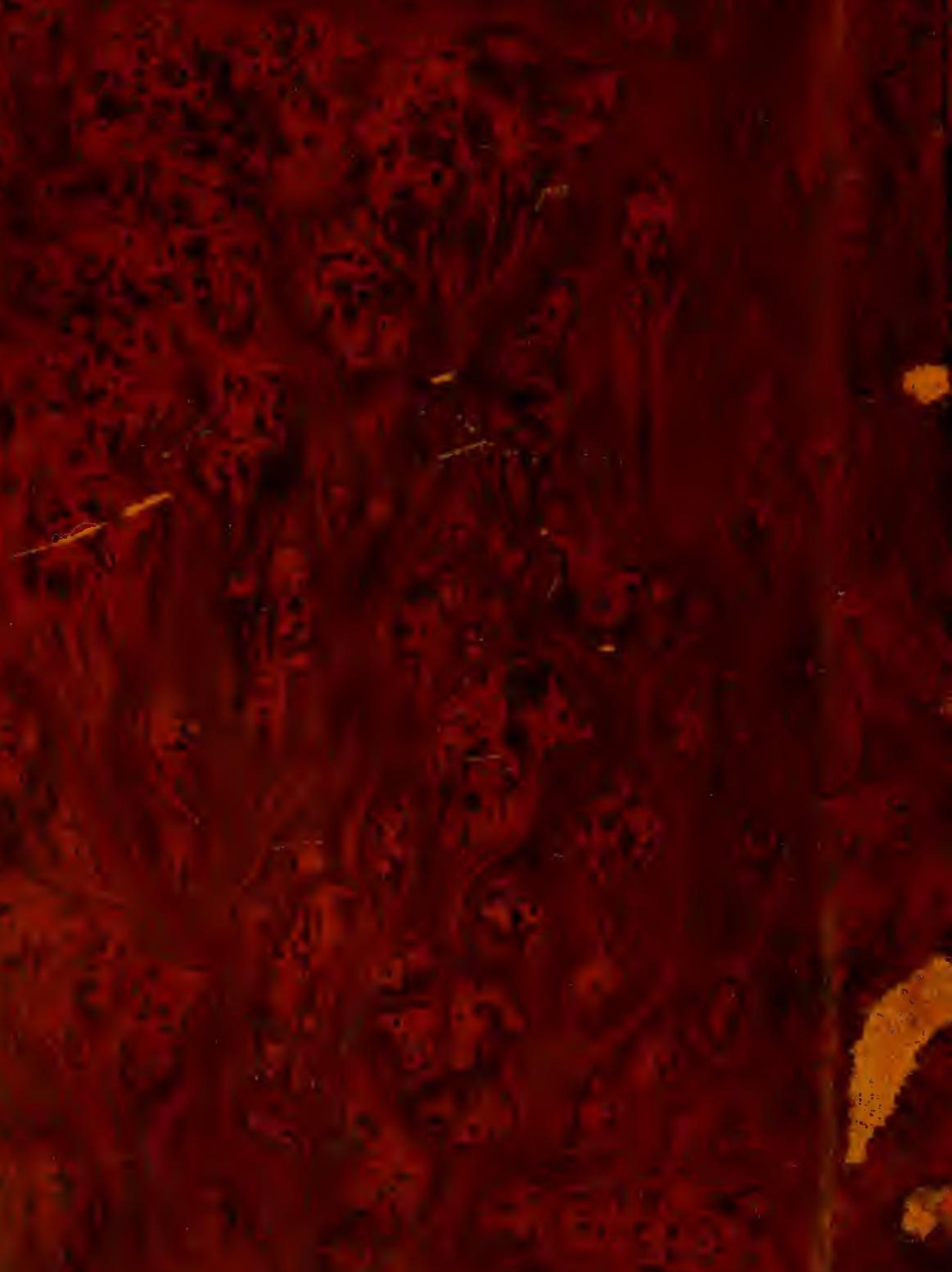